DOE/NASA CONTRACTOR

DOE/NASA CR-150870 REPORT

\title{
SOLAR HEATING AND HOT WATER SYSTEM INSTALLED AT LISTERHILL, ALABAMA
}

Prepared from documents furnished by

Reynolds Metals Company

Product Development Division

Richmond, Virginia 23261

Under DOE Contract G-77-A-01-4070

Monitored by the

National Aeronautics and Space Administration

George C. Marshall Space Flight Center, Alabama 35812

For the U. S. Department of Energy

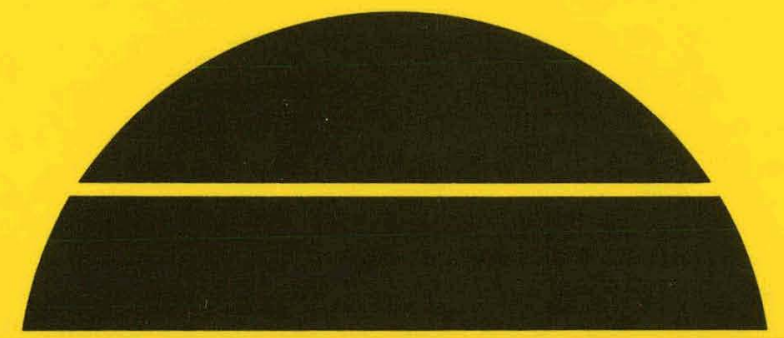

\section{U.S. Department of Energy}

MISTER MASTER

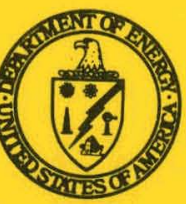




\section{DISCLAIMER}

This report was prepared as an account of work sponsored by an agency of the United States Government. Neither the United States Government nor any agency Thereof, nor any of their employees, makes any warranty, express or implied, or assumes any legal liability or responsibility for the accuracy, completeness, or usefulness of any information, apparatus, product, or process disclosed, or represents that its use would not infringe privately owned rights. Reference herein to any specific commercial product, process, or service by trade name, trademark, manufacturer, or otherwise does not necessarily constitute or imply its endorsement, recommendation, or favoring by the United States Government or any agency thereof. The views and opinions of authors expressed herein do not necessarily state or reflect those of the United States Government or any agency thereof. 


\section{DISCLAIMER}

Portions of this document may be illegible in electronic image products. Images are produced from the best available original document. 
This report was prepared to document work sponsored by the United States Government. Nelther the United States nor 1ts agents the United States Departmant of Energy, the United States Nat1onal Aeronautics and Space Adminletration, nor any federsl employees, nor any of thefr contractors, sutccritractors or their employees, make any warranty, express or imflitd, or assume any legal 11ability or ragnonsibility for the sccliacy, completeness, or usefulness of any information, apparatus, product or process disclosed, or represent that its use would not infringe privately owned r1ghts. 
PART I (DESIGN, INSTALLATION, AND CHECK-OUT)

INTRODUCTION • • • • • • • • • • • • • • • • • • • • • • • • 1

SUMMARY OF PROJECT INFORMATION . . . . . . . . . . . . . . . . 4

COST SUMMARY • • • • • • • • • • • • • • • • • • • • • • •

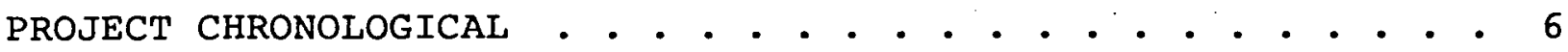

SYSTEM OPERATION AND CONTROL LOGIC . . . . . . . . . . . . . . 9

SYSTEM SCHEMATIC . . . . . . . . . . . . . . . . . . . . . 14

SYSTEM DESIGN CHANGES FROM ORIGINAL PROPOSAI.

AND CONSTRUCTION PROBLEMS . . . . . . . . . . . . . . . . . 15

ACCEPTANCE TEST PLAN . . . . . . . . . . . . . . . . . . 16

RESULTS OF ACCEPTANCE TESTS • • • • • • • . • • • • • • • . 29

INTERIM PERFORMANCE CRITERIA CERTIFICATION • • • • • • • • • • 39

PHOTOGRAPHS OF MAJOR COMPONENTS . . . . . . . . . . . . . . 40

PART II (MAINTENANCE MANIJAT,)

START-UP PROCEDURE . . . . . . . . . . . . . . . . . . . . . 46

OPERATING AND MAINTENANCE INSTRUCTIONS • • • • • • • • • • • 56

TROUBLE SHOOTING • • • . . . . . . . . . . . . . . . . . . 60

PRODUCT LITERATURE FOR SYSTEM COMPONENTS . . . . • • . • . . . 67

APPENDIX A - SOLAR COMMANDER AND SENSORS

APPENDIX B - REMOTE BULB TEMPERATURE CONTROLLERS

APPENDIX C - BELL AND GOSSETT 1535 PUMP

APPENDIX D - THRUSH : CENTRIFUGAL PUMPS

APPENDIX E - THRUSSH CIRCULATING PUMPS

APPENDIX F - STEEL AQUATOWERS

APPENDIX G - STORAGE TANK GAUGE CHART

This report was prepared as an account of work United States nor the United States Department of Energy, nor any of their employees, nor any of their contractors, subcontractors, or their employees, makes any warranty, express or implied, or aseumes any kega liability or responsibility for the accuracy, rompletenes or usefulness of any in formention, apparaus, produet or process disclosed, or represents the its use wouct or inituge privately owned rights.

APPENDIX H - SOLENOID VALVE

APPENDIX I - FLORATER BALANCING VALVE CHART

APPENDIX J - AIR RELEASE VALVE

APPENDIX $K$ - AS-BUILT DRAWINGS 


\section{INTRODUCTION}

1.0 A technical proposal for a solar space heating and potable hot water heating demonstration system at Reynolds Metals Shower and Change Facility in Listerhill, Alabama was submitted to Energy Research and Development Administration (now a part of U.S. Department of Energy) and was accepted. The solar system was designed to provide $79 \%$ of the estimated annual space heating load and $59 \%$ of the estimated annual potable hot water requirement. Back-up space heat is provided with an electric resistance heater and back-up hot water is provided with six 120 gallon electric hot water heaters.

2.0 The shower and change facility is similar to those widely used by industry. It has 3534 square feet of floor space and 3446 square feet of wall space. Thirty seven showers and 210 lockers are available in the facility. The building has double walls constructed of concrete blocks with styrofoam insulation between the walls.

3.0 The solar energy collection system consists of 80 Reynolds Metals flat plate aluminum collectors, a differential temperature controller, a pump, and a 5,000 gallon unpressurized underground steel storage tank. The solar working fluid is water that has been treated with NALCO 2755 inhibitor. All of the collectors are arranged to operate with the same pump and are installed with gravity drainage for freeze protection. 
4.0 The collectors are grouped in four arrays of twenty collectors each. Three arrays are mounted on the roof and the remaining array is mounted in a field on a concrete pad behind the building. All of the collectors are facing due south at a fixed tilt angle of 45 degrees. Each collector is a double-glazed $4^{\prime} \times 8^{\prime} \times 3-5 / 8 "$ panel with an effective collector area of approximately 30 square feet.

5.0 The stored solar energy can be used to provide space heat and/or potable hot water. Subject to demand and sufficient temperature differentials, space heat is provided by circulating water from the solar storage tank through a liquid-to-air heat exchanger mounted in the air duct. To heat potable water, water from the solar tank is circulated through a counterflow liquid-to-liquid heat exchanger where it heats water being circulated from the 1400 gallon potable water storage tank. The system also has the flexibility of giving priority to space heating if desired. If the temperature of the solar storage water reaches $185^{\circ} \mathrm{F}$, excess heat is dumped by circulating solar water through a counterflow liquid-to-liquid heat exchanger where it heats tap water being circulated from a commercial cooling tower.

6.0 The project was initiated in September, 1977 and declared operational in April, 1978 with the completion of the acceptance tests. The installation was dedicated on sun Day, May 3, 1978. 
7.0 This report describes, in considerable detail, the design, construction, start-up, acceptance testing, operation and maintenance of the solar system installed at Reynolds Metals Shower and Change Facility in Listerhill, Alabama. It is hoped this information and experience will be helpful to others who elect to use solar energy in similar applications. 


\section{SUMMARY OF PROJECT INFORMATION}

1.0 General Information

1.1 Owner: Reynolds Metals Company

Richmond, Virginia 23261

1.2 Contractor: Smith General Contractors, Inc. Florence, Alabama

1.3 Operational Date: April, 1978

1.4 Building:

1.4.1 Type: One story, flat roof, no windows.

1.4.2 Use: Shower and Change House

1.4.3 Floor Area: $3534 \mathrm{ft}{ }^{2}$

1.4.4 Construction: Double wall

1.4.5 Wall Material: Concrete blocks

1.4.6 Inculation: Styrofoam between blocks

2.0 Climatalogical Data

2.1 Latitude: $34^{\circ}-39^{\prime} \mathrm{N}$

2.2 Heating Degree Days: Yearly 3302; January 746

2.3 Peak Daily Insolation: $350 \mathrm{BTU} / \mathrm{ft} .{ }^{2}$

2.4 Yearly Sunshine: 58\% (Birmingham, Alabama data)

3.0 Solar Energy System

3.1 Application: Heating $79 \%$; hot water $59 \%$

3.2 Collector:

3.2.1 Type: Flat plate, Liquid

3.2.2 Glazing: Teflon inner; Tedlar outer

3.2.3 Absorber Material: Aluminum Alloy 1350-0

3.2.4 Absorber Coating: Siliconized Polyester Paint

3.2.5 Tilt Angle: $45^{\circ}$

3.2.6 Total Area: 2344 ft. 2 net

3.2.7 Manufacturer: Reynolds Metals Company

Richmond, Virginia 23261

3.3 Storage:

3.3.1 Medium: Water inhibited with NALCO 2755

3.3.2 Container: Underground, unpressurized steel tank

3.3.3 Capacity: 5000 gallons

4.0 Back-up System

4.1 Space Heat: Electrical Resistance

4.2 Hot Water: 6-120 gallon electric tanks 


\section{ALLOY SYSTEM COST SUMMARY}

Cost Element

- System Design

- Materials

- Frames

- Collectors

- Tanks

- Heat Exchangers

- Controls

- Others

- Construction \&

- Installation

- Mechanical

- Electrical

- General

- Tanks

- Project Management
Estimated Cost

$\$ \quad 38,107$

$\$ \quad 2,464$

$\$ 15,920$

$\$ \quad 8,764$

$\$ \quad 3,709$

$\$ 1,190$

$\$ \quad 3,677$

$$
\begin{array}{rr}
\$ & 29,357 \\
\$ & 7,955 \\
\$ & 14,952 \\
\$ & 4,640
\end{array}
$$

$\frac{\$ 13,089}{\$ 143,824}$

Actual Cost

$\$ \quad 39,917$

$\$ \quad 1,932$

$\$ 16,385$

$\$ \quad 8,954$

$\$ \quad 2,952$

$\$ 3,806$

$\$ 7,012$

$\$ 31,368$

$\$ 4,857$

$\$ 19,898$

$\$ \quad 3,829$

$\$ \quad 17,494$

$\$ 158,404$ 


\section{PROJECT CHRONOLOGICAL}

1.0 June, 1977 - Reynolds Metals was advised that its proposal for a solar energy demonstration project had been selected for negotiation of a cooperative agreement.

2.0 September, 1977 - Reynolds Metals was awarded a contract which stipulated that ERDA (now a part of DOE) would pay $\$ 71,916$ or $50 \%$ of the estimated total cost.

3.0 September, 1977 - A rinal Design Review was hold with government team (Planning Research Company and Marshall Space Flight Center personnel). Minor design and operation points were resolved and clarified.

4.0 October, 1977 - A preconstruction meeting was held with general contractor and his mechanical subcontractor to discuss construc- . tion and scheduling.

5.0 October, 1977 - The site preparation began. The site was partially graded and concrete foundations poured for the ground mounted collector array. Temporary roof protection and steel support foundations for roof mounted collector arrays were installed.

6.0 November, 1977 - The collector support stands were assembled and installed. The collectors and 5000 gallon steel storage tank were ready for installation. 
7.0 December, 1977 - All collectors were mounted to frames. Both liquid-to-liquid heat exchangers were mounted. Three pumps were mounted and approximately $30 \%$ of the plumbing was completed. Outside plumbing was delayed by severe inclement weather. The 5000 gallon storage tank was installed and backfilled. The installation and checkout (and therefore operation) were delayed approximately one month.

8.0 January, 1978 - The liquid-to-air (space heat) heat exchanger was installed. The concrete pad for cooling tower was poured and the cooling tower mounted (The fan motor for cooling tower had to be returned. The manufacturer had shipped a $110 \mathrm{~V}$ motor instead of a $440 \mathrm{~V}$ motor). The plumbing was approximately 758 complete, but no insulating or electrical work had been completed. Both plumbing and insulating were delayed another month by severe inclement weather. Also, late delivery of the 1400 gallon potable water preheat tank had prevented the plumbing contractor from completing his inside work. The control panel had been assembled and was ready for installation. A delay on open house was requested until May to allow ample time to have the system operating properly for dedication.

9.0 February, 1978 - All plumbing and electrical work had been completed. The insulation was $95 \%$ complete. The site grading was $85 \%$ complete. 
10.0 March, 1978 - Installation check-out and acceptance tests began on March 13, 1978. All acceptance tests were

- completed, with the exception of the heat dump test, during the week of March 20. The pump in the potable loop of the heat dump system was undersized and had to be replaced. The system was operational with the exception of the heat dump loop.

11.0 April, 1978 - The new pump was installed in the heat dump Eystem and the arreptance test was completed. The system was completely operational.

12.0 May, 3, 1978 - The open house and the dedication ceremony of installation was held in conjunction with Sun Day. Mr. John Blomquist, President of Reynolds Metals and Mr. Dan Henry, Government Project Manager, Marshall Space Flight Center, made short presentations to a group of about 65 local VIPs and news media personnel. Later in the day, the facility was opened to the public. 
(Reference RMCo Dwg. No. 45616107R and System Schematic)

1.0 Main Solar Loop - The main solar loop or solar energy collection system consists of 80 Reynolds collectors, a pump and a 5,000 gallon unpressurized underground steel storage tank. Water from the underground steel storage tank is circulated through the collectors where it is heated and then returned to the storage tank.

1.1 The solar collection loop is controlled with a differential temperature controller (1TC) which can be set for either manual or automatic operation. With the controller set on automatic, whenever the sensor located in the collector senses a temperature which is approximately $15^{\circ} \mathrm{F}$ greater than the sensor located in the solar storage tank, the controller (ITC) activates motor starter (IM) causing pump (IMTR) to circulate water between the collectors and the storage tank (The sensors are solid state thermistors which can provide accuracy from extended distances. The sensors are encapsulated in one-quarter inch copper tubing and are rated at temperatures of $300 \circ \mathrm{F})$. Circulation of the solar water continues until the differential temperature between the sensors drops to $5^{\circ} \mathrm{F}$ or the temperature of the solar water in the tank reaches a maximum temperature of 1900F. When either one of these conditions is reached, the controller (ITC) deactivates the solar pump (IMTR). The system will resume operation when the temperature 
differential reaches $15^{\circ} \mathrm{F}$ and/or the temperature of the solar water drops to $180^{\circ} \mathrm{F}$.

1.2 Motor starter (IM) also energizes a normally open solenoid valve (ISOL) in the drain-down by-pass line of the solar supply loop (This solenoid valve allows the solar collector loop to drain down when the system is not operating, thus providing freaze protection).

1.3 The water level in the solar storage tank is controlled by a conventional liquid level sensor. A totalizing flowmeter is located in the makeup water line in order to record the quantity of uninhibited water added to the system.

2.0 Heat Dump Loop - Excess heat from the solar storage tank is aumped by circulating the solar water through a counter-flow liquid-to-liquid heat exchanger where it heats tap water being circulated from a commercial cooling tower.

2.1 The heat dump (cooling tower) loop is controlled by a thermostat (3TAS) with a capillary located in the solar water storage tank which closes when the solar water temperature reaches $185^{\circ} \mathrm{F}$. Upon closing, the thermostat energizes control relay (2CR) which activates the motor starter for the cooling tower fan and motor starter (4M) which starts pumps (4MTR) and (5MTR). The pumps will continue to circulate water until the temperature of the solar water drops to approximately 
$175^{\circ} \mathrm{F}$ causing the thermostat to open and shut down the heat dump subsystem.

3.0 Space Heat Subsystem - Space heat is provided upon demand by circulating water from the solar storage tank through a liquid-to-air heat exchanger mounted in the air duct:

3.1 The space heat loop is controlled by thermostat (2TAS located in the locker room) connected in series with differential temperature controller (3TC) (The solar space heat thermostat is set approximately $2^{\circ} \mathrm{F}$ higher than the back-up furnace thermostat. This allows the solar heating system to activate first). When the locker room thermostat (2TAS) closes (calls for heat) and the controller (3TC) senses that the temperature of the solar water in the storage tank is $15^{\circ} \mathrm{F}$ or greater than the air temperature in the space heat duct, motor starter (3M) is activated. This causes pump (3MTR) to circulate solar water through the liquid-to-air heat exchanger mounted in the air duct. The system will continue to operate until the temperature differential between the solar water and air inside the duct drops to $5^{\circ} \mathrm{F}$ or the thermostat in the locker room opens.

3.2 The control system has a temperature limit switch (ITAS) which can be used to reserve all stored solar energy for space heating whenever the outside ambient is below a 
specified temperature. The temperature limit switch (1TAS) is connected in series with the differential temperature controller (2TC) for the potable hot water subsystem, and will not allow controller (2TC) to activate until the outside ambient reaches the preset temperature. (The temperature limit switch can be bypassed by setting switch (SS1) on the control panel to HAND position. Bypassing the temperature limit switch (ITAS) allows any stored solar energy to be used for space heating and/or potable hot water subjcot to temperature differentials and demand).

4.0 Potable Hot Water - Water from the solar storage tank is circulated through a counter-flow liquid-to-liquid heat exchanger where it heats potable water being circulated from a 1400 gallon potable water storage tank.

4.1 The potable hot water subsystem is controlled by a differential temperature controller (2TC). The controller has one sensor located near the top of the storage tank and the other sensor located near the bottom of the potable hot water tank. If the temperature of the water in the solar storage tank is ${ }^{\circ} \mathrm{F}$ higher than the temperature of the water in the 1400 gallon potable tank, the controller energizes control relay ( $1 \mathrm{CR}$ ) which in turn activates motor starter (2M) starting pumps (2MTR and 6MTR). The system will continue to operate until the differential temperature between the solar water and potable hot water drops to $5^{\circ} \mathrm{F}$. 
5.0 Schematic - The major components and operation of the various subsystems are shown in the schematic on the following page. 


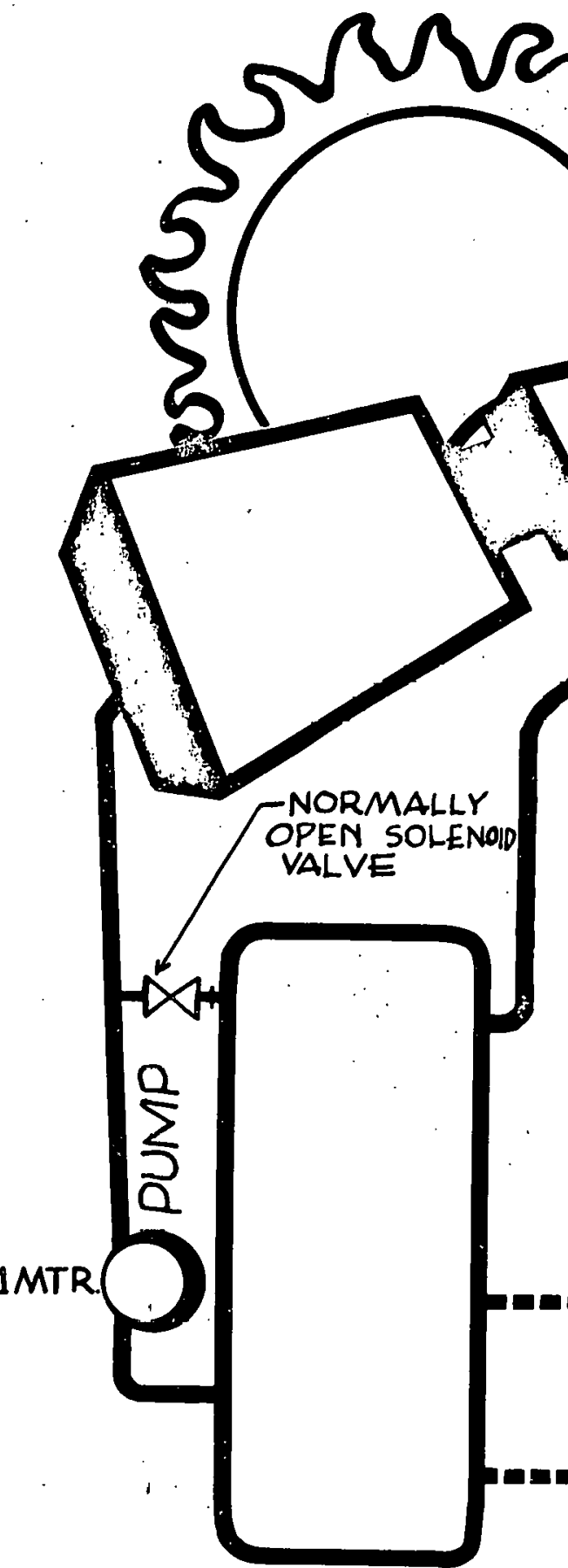

$5000 \mathrm{GAL}$. UNDER-GROUND STORAGE TANK
SYSTEM SCHEMATIC REYNOLDS METALS COMPANY ALLOYS SHEET \& PLATE PLANT SHEFFIELD, ALABAMA
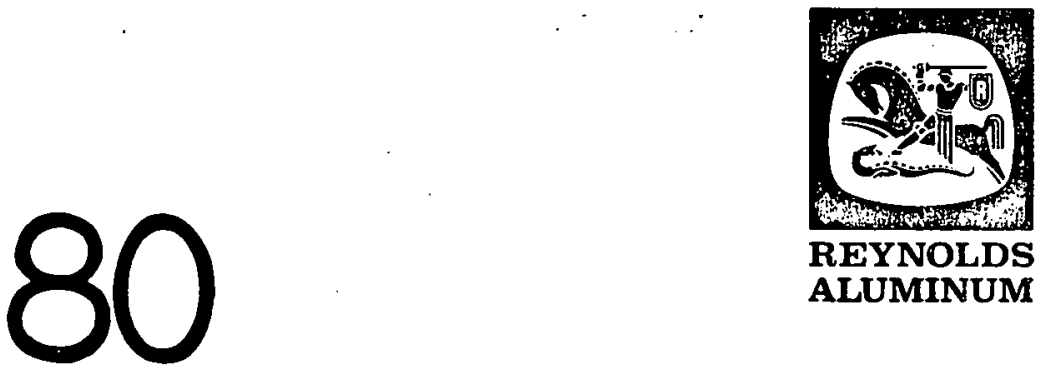

REYNOLDS ALUMINUM
REYNOLDS

SOLAR COLLECTORS

COOLING

TOWER

INSIDE BUILDING
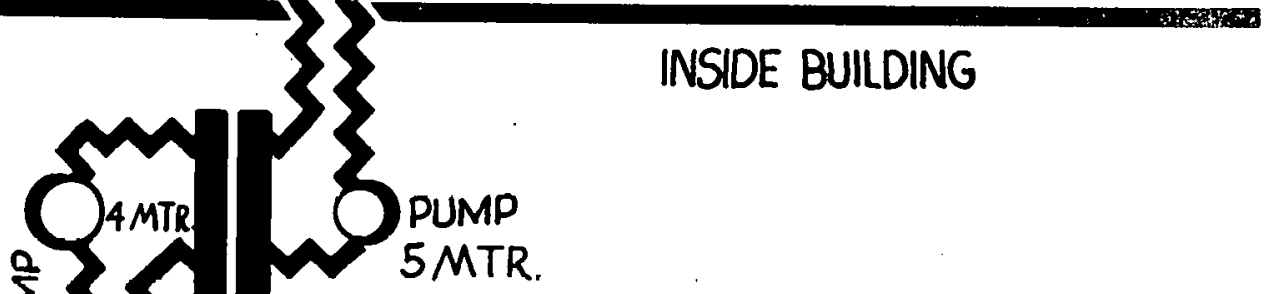

5 MTR.

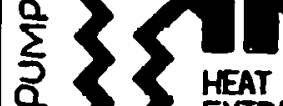

EXTRACTOR
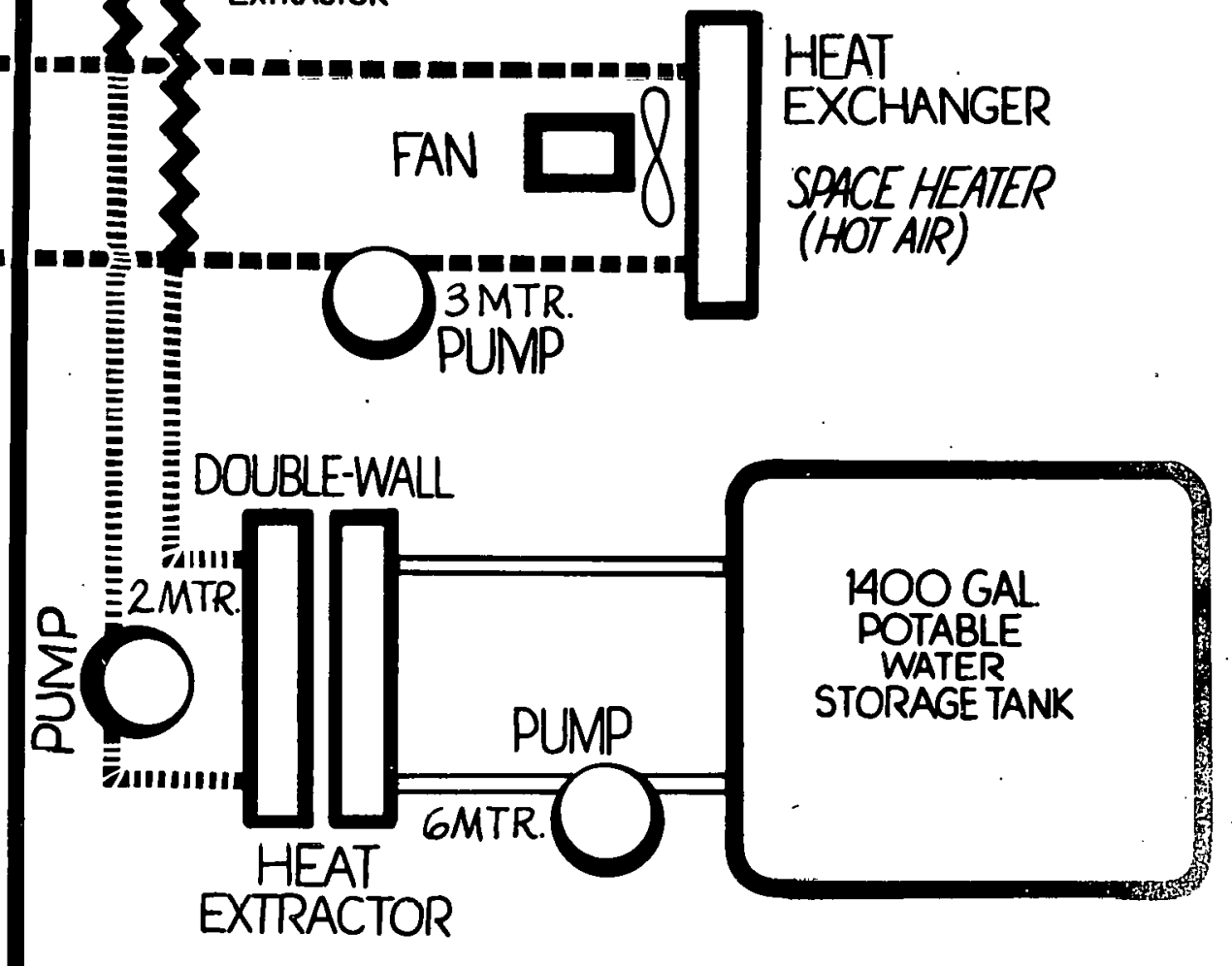
SYSTEM DESIGN CHANGES FROM ORIGINAL PROPOSAL AND CONSTRUCTION PROBLEMS

\subsection{Design Changes}

1.1 The spray pond in the heat dump system was changed to a cooling tower. The cooling tower was believed to be more practical and cost effective.

1.2 The dual prefabricated concrete storage tanks were changed to a single steel storage tank. Experience with a similar installation at another Reynolds Metals location indicated that a single storage tank would greatly simplify controls and reduce system down time.

\section{0 . Construction Problems}

2.1 The biggest construction problem was inclement weather conditions during December and January. The contractor was able to do very little outside work during these two months.

2.2 Late delivery of the 1400 gallon potable water tank delayed completion of the plumbing approximately two weeks.

2.3 An undérsized pump in the potable loop of the heat dump system delayed completion of. the acceptance test plan approximately two weeks.

2.4 The fan motor for the cooling tower had to be returned. The manufacturer shipped a $110 \mathrm{~V}$ motor instead of a $440 \mathrm{~V}$ motor. 


\section{ACCEPTANC.F. TEEST PLAN}

(Reference RMCo. Dwg. No. 45616107R)

1.0 Introduction - In order to verify that the completed solar system meets performance requirements, the various subsystems and their respective critical components or elements will be isolated and tested. The following acceptance test plan outlines the critical subsystem components to be tested, the test objectives, test requirements and test procedures. 
2.0 Collector Solar Loop - This loop circulates inhibited water through the collectors when heat can be gained and stores it in an underground unpressurized steel storage tank.

2.1 Leak Testing - Upon completion of installation, the solar loop will be isolated and hydrostatically tested at 50 psig minimum ( 60 psig maximum) for 15 minutes to insure that no leaks are present in system.

2.1.1 Install gate valves (or caps) in collector supply and return lines at unions as close to the storage tank as possible.

2.1.2 Cap or valve solar supply 3/4" drain down line at union as close as possible to solenoid valve (ISOL) on storage tank.

2.1.3 Close all gate valves installed in 2.1 .1 and 2.1 .2

2.1.4 Remove air release valve from one bank of collectors on roof and insert a nipple.

2.1.5 Fill system and all lines with tap water through nipple.

2.1.6 Remove nipple and replace air release valve.

2.1.7 Connect positive displacement pump at any convenient location.

2.1.8 Pressurize system to 50 psig minimum $(60$ psig maximum).

2.1.9 Maintain 50 psig minimum for 15 minutes and check each fitting and connection for leaks.

2.1.9.1 Repair all leaks. System must maintain 50 psig for 15 minutes after all leaks have been repaired.

2.1.10 Upon completion of pressure test, drain system (Test water not to be added to solar storage tank).

2.1.11 Disconnect positive displacement pump and reconnect piping.

2.1.12 Remove temporary gate valves or caps from supply, return and drain down lines of solar loop. Reconnect all lines to solar storage tank. 
2.2 Balancing Flow Rate of Collector Banks - The objective of this test will be to balance the flow rate in the solar loop. The main solar loop consists of four collector arrays with 20 collectors in each array. Each array is fitted with a differential pressure measuring device. Flow rates will be balanced in each array and the total flow rate recorded. A bypass valve parallel to the solar pump will be used to control the desired total flow through the collector arrays.

2.2.1 Deactivate all pumps by opening pump disconnect switches (IDISC through 6DISC).

2.2.2 Check solar loop pump (1MTR) for prime. IF PUMP NEEDS PRIMING, REFER TO SECTION 8.0 IN START-UP. PROCEDURE FOR PRIMING PRACTICES.

2.2.3 Check for proper operation of normally open solenoid valve in by-passline near underground solar storage tank (Solenoid valve (ISOL) must close when power is on to pump).

2.2.4 Open all 1-1/2" valves and all florater valves in solar loop. Close $3 / 4 "$ valve in pump (IMTR) by-pass.

2.2.5 Set switch of solar loop controller (1TC) on MANUAI.

2.2.6 Start solar loop pump (IMTR) by closing pump disconnect switch (IDISC).

2.2.7 Using Thrush Model 832 Florater meter and Thrush Florater balancing valve, check and/or set flow rate on ground mounted collectors (Optimum flow rate 10 to $13 \mathrm{gpm}$ ).

2.2.7.1 Open carrying case and place test kit in a convenient spot on test site with test kit horizontal.

2.2.7.2 With test kit balance valve closed, connect hoses to florater - Red hose upstream, high pressure - Green hose downstream, low pressure.

2.2.7.3 Open test kit balance valve.

2.2.7.4 Open high and low bleed valves alternately to purge air from system (Bleed water discharges from convenient clear plastic flexible tube). 
2.2.7.5 When bleeding shows all air removed, close test kit balance valve and read differential pressure gauge. Refer to chart in Appendix I in Maintenance Manual for conversion to gpm and additional instructions.

2.2.7.6. When test is complete, open test kit balance valve and disconnect test hoses from florater.

2.2.7.7 Store hoses by coiling them around the test kit panel.

2.2.8 Check and/or set florater on each bank of roof mounted collectors using the above procedure (Optimum flow rate 10 to $13 \mathrm{gpm}$ per collector bank).

2.2.9 Recheck flow rate on ground mounted collectors and adjust if needed.

2.2.10 Repeat $2.2 .7,2.2 .8$ and 2.2 .9 until flow rates approximately equal.

2.2.11 If florater setting is over 50, open pump (IMTR) by-pass valve slightly.

2.2.12 Repeat 2.2 .10 and 2.2 .11 until flows are equal and at desired rate and florater is operating in lower range.

2.2.13 Record flow rate for each collector array.

2.2.14 Shut off pump (IMTR) by opening disconnect switch (lDISC).

2.2.15 Move switch of solar loop controller (1TC) to OFF position.

2.3 Collector Array and Piping Heat Collection Efficiency The objective of this test will be to determine the collector array and piping heat collection efficiency. This requires that the total solar insolation available to the collector array and the net heat delivered to the storage tank be measured. The procedure will be to record the solar flux while simultaneously recording the inlet and outlet water temperatures and flow rates in the collector system. This data, along with the ambient temperatures, will provide a means of comparing the actual performance to the projected design performance. 
2.3.1 Install thermocouple in tees at inlet and outlet of one array and connect to readout.

2.3.2 Install thermocouple for ambient temperature and connect to readout.

2.3.3 Install pyranometer on collector frame. Pyranometer must be oriented in same direction as collectors and connected to readout.

2.3.4 Deactivate all pumps by opening pump disconnect switches (IDISC through 6DISC).

2.3.5 Set switch of solar loop controller (1TC) on AUTO (Temperature of collector must be $15^{\circ}$ higher than temperature of water in solar storage tank for system to operate automatically).

2.3.6 Start pump (IMTR) to solar loop by closing disconnect switch (IDISC). BE SURE PUMP IS PRIMED BEFORE ATTEMPTING TO START PUMP.

2.3.7 Record solar flux while simultaneously measuring inlet and outlet water temperature and flow rates in collector system plus ambient temperature.

2.3.8 Upon completion of test, shut off pump (IMTR) by opening disconnect switch (IDISC).

2.3.9 Move switch of solar loop controller (1TC) to OFF position.

2.3.10 Analyze and plot data:

2.4 Heat Loss from Storage Tank - The objective of this test will be to determine the heat losses from the storage tank. This requires that the solar water in the tank be heated to a known temperature (MINIMUM WATER TEMPERATURE $120^{\circ} \mathrm{F}$, PREFERRED WATER TEMPERATURE $140^{\circ}$ OR ABOVE). The test procedure will be to place several thermocouples at various depths within the storage tank and to record the temperature drop versus time with the solar system deactivated. The volume of water and water-to-wall surface area will be recorded.

2.4.1 Deactivate system by opening all pump disconnect switches (IDISC through 6DISC). 
2.4.2 Shut off make-up water to solar storage tank.

2.4.3. Install thermocouples at three levels (l foot from bottom, midway and at 1-6 inches below. water surface) and connect to readout.

2.4.4 Determine water level and/or volume in solar storage tank (See tank chart in Appendix G in Maintenance Manual).

2.4.5 Record temperature measurement at one hour intervals for four hours minimum.

2.4.6 Calculate overall heat transfer loss through. wall of tank.

2.5 Freeze Protection - The objective of this test is to insure that freeze protection is provided by the gravity drain system. The basic requirement is that all or virtually all of the water in the collectors and piping drain back into the storage tank when the solar pump has been deactivated.

2.5:1 Inspect all collectors to see that they were installed in horizontal position plus or minus $1 / 8^{\prime \prime}$

2.5.2 Inspecl all luses and piping to insure that there are no high or low places where water can be trapped during drain down. (All areas that appear low are to be disconnected to check for the presence of water after drain down.)

2.5.3 Using a four-foot carpenter's level, check to see that all piping is sloped to gravity drain when system is deactivated.

2.5.4 Check to see that normally open solenoid in by-pass line at tank is closed when system is activated. 
3.0 Subsystem Leak Tests - The solar water side of the heat dump, space heating and hot water subsystem are to be hydrostatically tested at 50 psig. minimum (60 psig maximum) for 15 minutes to insure that no leaks are present. All potable water loops are to be hydrostatically tested at 125 psig minimum (150 psig maximum) for 15 minutes without leaking.

3.1 Solar Water Side for Heat Dump, Space Heating and Hot Water Subsystem

3.1.1 Install gate valves or caps in solar water supply and return lines at unions as close to solar storage tank as possible (Valves or caps must be installed at a location where supply and return lines are common to all three subsystems).

\subsubsection{Close all valvec inctalled in above step.}

3.1.2 Fill all lines in solar water loop of each subsystem with tap water at any convenient. location (Use sill cock or other suitable valve and/or fitting to facilitate hose connection for, filling and attachment of positive displacement pump for pressure testing).

3.1.3 Vent each subsystem while filling by loosening a plug or union at the highest point of each line. Retighten plug or union after venting completed.

3.1.4 Connect positive displacement pump and pressurize system to 50 psig ( 60 psig maximum).

3.1.5 Maintain 50 psig for 15 minutes and check all fittings and connections for leaks.

3.1.5.1 Repair all leaks (System must maintain 50 psig for 15 minutes continuous after all leaks have been repaired).

3.1.6 Disconnect positive displacement pump, drain system and reconnect piping (Test water not to be added to solar storage tank).

3.1.7 Remove temporary gate valves or caps from supply and return lines and reconnect lines to solar storage tank. 
3.2 Potable Water Subsystems and Loops

3.2.1 All potable water subsystems and loops to be hydrostatically pressure tested at 125 psig minimum (150 psig maximum) for 15 minutes using standard plumbing practices.

3.2.2 Repair all leaks. (System must maintain 125 psig minimum for 15 minutes continuous after all leaks have been repaired). 
4.0 Heat Dump Subsystem - The objective of this test will be to measure the rate of heat dissipation when the cooling tower is operating. The basic design requirement is that the cooling tower dump at least be $1.6 \times 10^{6}$ BTU in a 24-hour interval. The procedure will be similar to that used in determining storage tank loss (Section 2.4) except that the pumps to the cooling tower heat exchanger will be activated (WATER IN SOLAR STORAGE TANK MUST BE HEATED TO $120^{\circ} \mathrm{F}$ MINIMUM WITH $140^{\circ} \mathrm{F}$ OR ABOVE PREFERABLE).

4.0.1 Deactivate system by opening all pump disconnect switches (IDISC through 6DISC).

4.0.2 Shut off make-up water supply to solar storage tank.

4.0.3 Check to see that cooling tower is filled with water and fan is operating properly (Refer to section 9.0 of Start-up Procedure in Maintenance Manual).

4.0.4 Manually operate heat dump subsystem pumps.

4.0.4.1 Check to see that pumps are primed (Refer to section 8.0 in Start-up Procedure in Maintenance Manual).

4.0.4.2 start pump (4MTR) in solar side and liunze c1rculator (SMTR) in potable water side of cooling tower heat exchanger by placing switch (SS3) in HAND position and closing disconnect switrh (4DISC and 5DISC) to each pump.

1.0.5 Measure Lemperature of water in solar storage tank with thermocouple at three levels ( 1 foot from bottom, midway and at 1-6 inches below water surface at top of tank).

4.0.6 With heat dump subsystem operating, record temperature measurements of each thermocouple at one-hour intervals for four hours minimum.

4.0.7 Upon completion of test, shut down system by opening pump disconnect switches (4DISC and 5DISC).

4.0.8 Determine water level and/or volume in solar storage tank (See tank chart in Appendix G in Maintenance Manual).

4.0.9 Determine rate of heat dissipation. 
5.0 Space Heat Subsystem - The objective of this test is to insure that design heat delivery can be achieved. The test procedure consists of measuring the liquid flow rate to the heat exchanger with a differential pressure device and measuring the temperature drop in the liquid across the heat exchanger. Transfer line heat losses will be determined by recording the temperature drop between the outlet of the storage tank and the inlet to the heat exchanger (WATER IN TANK MUST BE HEATED TO $120^{\circ} \mathrm{F}$ MINIMUM WITH $1.40^{\circ}$ F OR ABOVE PREFERABLE).

5.0.1 Install thermocouples on inlet and outlet of solar side of space heat exchanger and on solar supply line at connection to solar storage tank.

5.0.2 Set switch of space heat solar controller (3TC) On MANUAL.

5.0.3 Activate pump (3MTR) for space heating system by moving switch (SS2) in control panel to HAND position and closing pump disconnect switch (3DISC) (CHECK TO SEE THAT PUMP IS PRIMED).

5.0.4 Shut off back-up space heating system by turning thermostat in locker room down or shut off power.

5.0.5 Using Thrush Model 832 Florater meter and Thrush Florater balancing valve (located at heat exchanger outlet), determine flow rate through heat exchanger at 5 to 10-minute intervals for one-hour minimum.

5.0.5.1 Open carrying case and place test kit in a convenient spot on test site with test kit horizontal.

5.0.5.2 With test kit balance valve closed, connect hoses to florater - Red hose upstream, high pressure - Green hose downstream, low pressure.

5.0.5.3 Open test kit balance valve.

5.0.5.4 Open high and low bleed valves alternately to purge air from system (Bleed water discharges from convenient clear plastic flexible tube).

5.0.5.5 When bleeding shows all air removed, close test kit balance valve and read differential pressure gauge. Refer to chart in Appendix I in Maintenance Manual for conversion to $\mathrm{gpm}$. 
5.0.6 Simultaneously record temperature at inlet and outlet of heat exchanger and supply line connection to tank for each corresponding flow rate.

5.0.7 When test is complete, open test kit balance valve before disconnecting test hoses from florater.

5.0.7.1 store hoses by coiling them around the test panel.

5.0.8 Restore system to normal operating mode. Shut pump (3MTR) off by opening pump disconnect switch (3DISC).

5.0.9 Compute heat delivered and transfer line losses. 
6.0 Hot Water Subsystem - The objective of this test is to determine if the design heat transfer rate is obtained. The test requires the measurement of the temperature drop across the heat exchanger on the solar side while simultaneously recording the flow rate via a differential pressure device (WATER IN TANK MUST BE HEATED TO $120^{\circ} \mathrm{F}$ MINIMUM WITH $140^{\circ} \mathrm{F}$ OR ABOVE PREFERABLE).

6.0.1 Install thermocouple on inlet and outlet of solar side of potable water heat exchanger and on supply piping outlet to underground storage tank.

6.0.2 Deactivate solar space heat subsystem by turning solar space heat thermostat down or off.

6.0.3 Turn showers on to create demand for hot water if needed.

6.0.4 Set switch of potable water solar controller (2TC) on MANUAL.

6.0.5 Activate pumps (2MTR and 6MTR) for both sides of potable hot water heat exchanger by moving switch (SS1) in control panel to HAND position and closing disconnect switches (2DISC and 6DISC). CHECK PUMP FOR PRIME - FOR PUMP, PRIMING PRACTICE, REFER TO SECTION 8.0 IN START-UP PROCEDURE.

6.0.6 Using Thrush. Model 832 Florater meter and Thrush Florater balancing valve (located at heat exchanger inlet), determine flow rate through heat exchanger at 5 to 10-minute intervals for one hour minimum.

6.0.6.1 Open carrying case and place test kit in a convenient spot on test site with test kit horizontal.

6.0.6.2 With test kit balance valve closed, connect hoses to florater. Red hose upstream, high pressure - Green hose downstream, low pressure.

6.0.6.3 Open test kit balance valve (bottom of panel).

6.0.6.4 Open high and low bleed valves alternately to purge air from system (Bleed water discharges from convenient clear plastic flexible tube). 
6.0.6.5. When bleeding shows all air removed, close test kit balance valve and read differential pressure gauge, Refer to chart in Appendix I in Maintenance Manual for conversion to gpm.

6.0.7 Simultaneously record temperature at inlet and outlet of heat exchanger and supply line connection to solar storage tank for each corresponding flow rate.

6.0 .8 When test is complete, open test kit balance valve before disconnecting test hoses from florater.

6.0.8.1 Store hoses by coiling them around the test panel.

6.0 .9 Restore system to normal operating mode. Shut pumps off by opening pump disconnect switches (2DISC and 6DISC).

6. 0:10 Compute heat delivered and transfer line losses. 
1.0 Introduction

A series of performance tests was conducted on the solar system to demonstrate various performance requirements.

\subsection{Collector Solar Loop}

2.1 The solar loop was hydrostatically pressure tested at 50 psig. All leaks were repaired.

2.2 The flow rate was balanced in each collector array at approximately $11 \mathrm{gpm}$.

2.3 The heat collection efficiency of one collector array and its associated piping was determined. The results are shown in Tables 1,2 and 3 .

2.4 The heat loss from the underground storage tank was found to be negligible over an 8.5 hour period. The data is shown in Table 4.

2.5 All collectors and piping were inspected to ensure that they were installed with the correct slope for drainage.

\subsection{Subsystem Leak Tests}

3.1 The solar loop of the heat dump, space heating and potable hot water heating subsystems were hydrostatically pressure tested at 50 psig. All leaks were repaired.

3.2 All subsystem potable water loops were hydrostatically pressure tested at 125 psig. All leaks were repaired.

4.0 Heat Dump Subsystem

The rate of heat dissipation through the cooling tower was found to be approximately 1.33 million BTU/24 hours (Test \#1) and $2.65 \mathrm{million}$ BTU/24 hours (Test \#2). The data is shown in Table 5 .

5.0 Space Heat Subsystem

The heat transferred through the exchanger in the air heating duct was. found to be $247,840 \mathrm{BTU} / \mathrm{Hr}$. (Test \#1) and 169,589 BTU/Hr. (Test \#2) The heat losses in the space heat transfer lines were found to be negligible as evidenced by comparison of the inlet temperature at heat exchanger and tank outlet (See Table 6).

\subsection{Potable Hot Water}

The heat transferred through the potable water heat exchanger was $50,916 \mathrm{BTU} / \mathrm{Hr}$. Data is shown in Table 7 .

7.0 Summary A comparison of actual and expected performance is 
TABLE 1

COLLECTOR ARRAY EFFICIENCY TEST DATA

\begin{tabular}{|c|c|c|c|c|c|}
\hline Time & $\begin{array}{c}\text { Collector } \\
\text { Array } \\
\text { Inlet } \\
\text { Temperature } \\
\text { (OF) } \\
\end{array}$ & $\begin{array}{c}\text { Collector } \\
\text { Array } \\
\text { Outlet } \\
\text { Temperature } \\
\left(O_{F}\right) \\
\end{array}$ & $\begin{array}{c}\text { Outside } \\
\text { Ambient } \\
\text { Temperature } \\
\left(O_{F}\right) \\
\end{array}$ & $\begin{array}{l}\text { Flow } \\
\text { (gpm:) }\end{array}$ & $\begin{array}{l}\text { Pyranometer } \\
\text { (BTU/Hr. Ft.2) }\end{array}$ \\
\hline $9: 30$ am & 112 & 123 & 52 & 11.5 & 200 \\
\hline $10: 00 \mathrm{am}$ & 115 & 128.5 & 57 & 11.5 & 220 \\
\hline $10: 30 \mathrm{am}$ & 117.5 & 132 & 55.5 & 11.5 & 240 \\
\hline $11: 00 \mathrm{am}$ & 122 & 137 & 62 & 11.75 & 250 \\
\hline $11: 30 \mathrm{am}$ & 127 & 142 & 69 & 11.75 & 255 \\
\hline $12: 40 \mathrm{pm}$ & 137 & 152.5 & 68 & 11.75 & 260 \\
\hline $1: 00 \mathrm{pm}$ & 142 & 155 & 63 & 11.75 & 250 \\
\hline $1: 45 \mathrm{pm}$ & 148 & 159 & 69 & 11.75 & 240 \\
\hline $2: 00 \mathrm{pm}$ & 149.5 & 160 & 69.5 & 11.75 & 230 \\
\hline $2: 30 \mathrm{pm}$ & 153 & 160.5 & 66 & 11.75 & 200 \\
\hline
\end{tabular}


TABLE 2

\section{COLLECTOR ARRAY EFFICIENCY TEST} (DATA PERIOD AVERAGES)

\begin{tabular}{|c|c|c|c|c|c|}
\hline Time & $\begin{array}{c}\mathrm{T}_{\mathrm{i}} \\
\text { Avg. Inlet } \\
\text { Temperature } \\
\left(\mathrm{O}_{\mathrm{F}}\right)\end{array}$ & $\begin{array}{c}\mathrm{T}_{\mathrm{O}} \\
\text { Avg. Outlet } \\
\text { Temperature } \\
\left(\mathrm{O}_{\mathrm{F})}\right. \\
\end{array}$ & $\begin{array}{c}\mathrm{T}_{\mathrm{a}} \\
\text { Avg. Ambient } \\
\text { Temperature } \\
\left(\mathrm{O}_{\mathrm{F})}\right. \\
\end{array}$ & $\begin{aligned} \text { Avg. I } \\
\text { (BTU/Hr. Ft. }{ }^{2} \text { ) } \\
\end{aligned}$ & $\begin{array}{l}\text { Avg. Flow } \\
(\text { gpm }) \\
\end{array}$ \\
\hline $9: 30$ am & & & & & \\
\hline $10: 00 \mathrm{am}$ & 113.5 & 125.75 & 54.5 & 210 & 11.5 \\
\hline 20 & 116.25 & 130.25 & 56.25 & 230 & 11.5 \\
\hline I0:30 dil & 119.75 & $\quad 134.5$ & 58.75 & 245 & 11.63 \\
\hline $11: 00$ am & 124.5 & 139.5 & 65.5 & 252.5 & 11.75 \\
\hline $12: 40 \mathrm{pm}$ & 132 & 145.25 & 68.5 & 257.5 & 11.75 \\
\hline $1: 00 \mathrm{pm}$ & 139.5 & 153.75 & 65.5 & 255 & 11.75 \\
\hline $1: 45 \mathrm{pm}$ & 145 & 157 & 66 & 245 & 11.75 \\
\hline $2: 00 \mathrm{pm}$ & 148.75 & 159.5 & 69.25 & 235 & 11.75 \\
\hline $2: 30 \mathrm{pm}$ & 151.25 & 160.25 & 67.75 & 215 & 11.75 \\
\hline TOTAL & 1190.5 & 1305.75 & 572 & 2145 & 105.13 \\
\hline AVERAGE & 132.28 & 145.08 & 63.6 & 238 & 11.68 \\
\hline
\end{tabular}




\section{TABLE 3}

COLLECTOR ARRAY EFFICIENCY TEST

(CAL_ULATED VALUES)

\begin{tabular}{|c|c|c|c|c|c|c|c|}
\hline Time & $\begin{array}{c}{ }_{\text {Avg. }}^{\mathrm{Tp}^{*}} \mathrm{Plate}^{\mathrm{P}} \\
\text { Temperature } \\
(\mathrm{F})\end{array}$ & 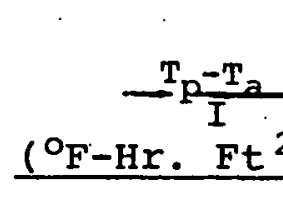 & (BTU) & $\begin{array}{c}Q \\
\text { Heat Collected } \\
\text { (BTU/Min) } \\
\end{array}$ & $\begin{array}{r}\text { Heat } \\
\text { Per Ft. } \\
\text { (BTU } \\
\end{array}$ & $\begin{array}{l}Q^{\prime} \\
\text { Collected } \\
\text { of Collector } \\
\text { /Hr. Ft' }\end{array}$ & $\begin{array}{c}\text { Coliector } \\
\text { Array } \\
\text { Efficiency } \\
(8) \\
\end{array}$ \\
\hline $9: 30$ am & & & & & & ${ }^{\circ}$ & \\
\hline & 119.6 & .310 & & 1173.49 & & 121.4 & 57.8 \\
\hline $10: 30 \mathrm{am}$ & 123.3 & .291 & & 1341.13 & & 138.7 & 60.3 \\
\hline $11.00 \mathrm{am}$ & 127.1 & .279 & & 1428.33 & & 147.8 & 60.3 \\
\hline $11: 30 \mathrm{am}$ & .132 & .263 & & 1468.16 & . & 151.9 & 60.2 \\
\hline $12: 40 \mathrm{pm}$ & 138.6 & .272 & - & 1296.88 & & 134.2 & $\because 52.1$ \\
\hline $1: 00 \mathrm{pm}$ & 146.6 & $: 318$ & & 1394.75 & & 144.8 & 56.8 \\
\hline $1: 45 \mathrm{pm}$ & 151 & .347 & & 1174.53 & & 121.5 & 49.6 \\
\hline $2: 00 \mathrm{pm}$ & 149.9 & .343 & & 1052.18 & . & 108.9 & 46.3 \\
\hline $2: 30 \mathrm{pm}$ & $\begin{array}{c}155.75 \\
\therefore \\
\end{array}$ & .409 & & 880.90 & & 91.1 & 42.4 \\
\hline Averages & 138.7 & .316 & & 1245.4 & & 128.8 & 54.1 \\
\hline
\end{tabular}


TABLE 4

UNDERGROUND STORAGE TANK LOSSES

\begin{tabular}{|c|c|c|c|}
\hline Time & $\begin{array}{c}\text { - Temperature } \\
6 . " \text { From } \\
\text { Bottom of Tank } \\
\left(O_{\mathrm{F})}\right. \\
\end{array}$ & $\begin{array}{c}\text { Temperature } \\
48 " \\
\text { Mid-way of Tank } \\
\left(\sigma_{F}\right)\end{array}$ & $\begin{array}{c}\text { Temperature } \\
6 " \text { Below } \\
\text { Top of Water Surface } \\
\text { (OF) } \\
\end{array}$ \\
\hline $12: 55 \mathrm{pm}$ & 147 & 147.5 & 146 \\
\hline $1: 55 \mathrm{pm}$ & 146 & 148 & 147 \\
\hline $2: 50 \mathrm{pm}$ & 146 & 148 & 147 \\
\hline $3: 50 \mathrm{pm}$ & 146 & 148 & 148 \\
\hline $4: 45 \mathrm{pm}$ & 146 & 148 & 149 \\
\hline $9: 30 . \mathrm{pm}$ & 145 & 148 & 148 \\
\hline
\end{tabular}

Date of Test: $3-21-78$ 
TABLE 5

HEAT DISSIPATED BY COOLING TOWER

est \#1

\section{$\underline{\text { Time }}$}

$8: 34$ am

$9: 34$ am

$0: 34$ am

$1: 34$ am

$2: 34 \mathrm{pm}$

est \#2

$: 15$ am

$1: 15$ am

$2: 15$ pm

$l: 15 \mathrm{pm}$

$2: 15 \mathrm{pm}$

\begin{tabular}{c}
$\begin{array}{c}\text { Temp. at Top of } \\
\text { Storage Tank } \\
\text { (OF) }\end{array}$ \\
\hline 125 \\
124 \\
124 \\
124 \\
123
\end{tabular}

Temp. at Middle of Tank

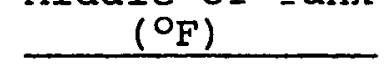

122

123.5

123

121

117

Temp. at

Bottom of Tank

(OF)

122

116

113.5

110

108

157

156.5

157

156

155

155

155

148

1.43

140.5

136
Heat Remaved From Lower

Half of Tank

(BTU/Hr.)

Heat Removed From Upper

Half of Tank

(BTU/Hr.)

$$
\begin{aligned}
& 22,907.5 \\
& 39,567.5 \\
& 4 \Xi, 732.5 \\
& 60,392.5
\end{aligned}
$$$$
13,015.6
$$$$
41,650
$$$$
\text { TOTAL -- } \frac{221,786}{202,042,5}
$$
Removed

23,428

$39,567.5$

$56,748.1$

$02,042.5$

TOTAL -- 221,786
Total Heat (BTU/Hr.)

Average Heat Dissipated - 55,447 BTU/ $\mathrm{Hr}$.

$\begin{array}{ccr}77,052 & 9,996 & 87,049 \\ 79,135 & 29,988 & 109,123 \\ 66,640 & 49,980 & 116,620 \\ B 9,548 & 39,984 & 129,532 \\ & \text { TOTAL }- & 442,324\end{array}$

Average Heat Dissipated -- 110,580 BTU 
TABLE 6 .

SPACE HEAT TEST

Test \#1

Temp. of Solar Water at Inlet to Heat Exchng.

Time

$9: 55$ am

$10: 10 \mathrm{am}$

$10: 25$ am

$10: 40$ am

$10: 55 \mathrm{am}$

Test \#2

$8: 15 \mathrm{am}$

$8: 30$ am

$8: 45$ am

$9: 00$ am

$9: 15$ am

109

108

107 $\begin{array}{ll}\text { Temp. of Solar } & \text { Temp. O⿱亠 } \\ \text { Water at Outlet } & \text { Solar Water }\end{array}$

from Heat Exchng. Leaving Tank

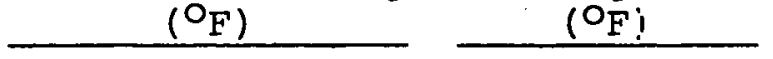

103

111

102

$110^{\circ}$

102

109

100

108

100

107

$\begin{array}{ll}177 & 166 \\ 176.5 & 166 \\ 176.5 & 166 \\ 175 & 161.5 \\ 172 & 162\end{array}$

177

180

175.5

175.5

172
Flow Average Total Heat

Through Heat Removed

Heat Exchng. Removed Through Exchng.

(gpm) (BTU/Min.) (BTU)

44.5

44.5

2965.5

44,483

2780.1

41,702

44.5

44.5

2780.1

41,702

2780.1

41,702

44.5

TOTAI BTU/Hr. - 169,539

44

44.25

44.5

44.5

44.5
57,728

3870.3

58,055

4448.2

66,723

4355.6

65,334

TCTAL BTU/Hr. - 247,840

Date of Test \#1: 3-17-78; Date of Test \#2: 3-20-78 
TABLE 7

POTABLE WATER TEST

\section{Time}

$9: 50$ am

$10: 00 \mathrm{am}$

$10: 15$ am

$10: 30$ am

$10: 45 \mathrm{am}$

$11: 00 \mathrm{am}$

$11: 15$ am

$11: 30 \cdot \mathrm{am}$

$12: 30 \mathrm{pm}$
H.E. Inlet Temp.

\begin{tabular}{l}
$(O F)$ \\
\hline 157 \\
156 \\
156 \\
156 \\
155 \\
155 \\
155 \\
155 \\
153.5
\end{tabular}

\begin{tabular}{c} 
H.E. Outlet Temp. \\
$\left(O_{F}\right)$ \\
\hline 140.5 \\
141 \\
141 \\
141 \\
141 \\
141 \\
142 \\
143 \\
145
\end{tabular}

Total Heat

Removed thru

Exchanger

\begin{tabular}{c}
$\begin{array}{c}\text { Flow } \\
(\mathrm{gpm})\end{array}$ \\
\hline 8 \\
8 \\
8 \\
8 \\
8 \\
8 \\
8 \\
8 \\
8
\end{tabular}

Average

(BTU/Min)

(BTU)

1049.6
999.6
999.6
966.3
933.0
899.6
833.0
683.1

10,496

14,994

14,994

14,494

13,994

13,495

12,495

40,984

TOTAL BTU/2.67 hrs. - 135,946

AVG. BTU/hr. - $\quad 50,916$ 
TABLE 8

SUMMARY AND COMPARISON OF EXPECTED AND ACTUAL PERFORMANCE

\section{Subsystem}

Space Heat

Hot Water

Cooling Tower

\section{Expected Performance}

43,000 BTU/Hr iMin. Design Capacity)

$47,467 \mathrm{BTU} / \mathrm{Hr}$.

$1.6 \times 10^{6} \mathrm{BTU} / 24 \mathrm{Hr}$.

\section{Test Results}

169,589 to $247,840 \mathrm{BTU} / \mathrm{Hr}$.

$50,916 \mathrm{BTU} / \mathrm{Hr}$.

$1.33 \times 106$ to $2.7 \times 106 \mathrm{BTU} / 24 \mathrm{Hr}$. 


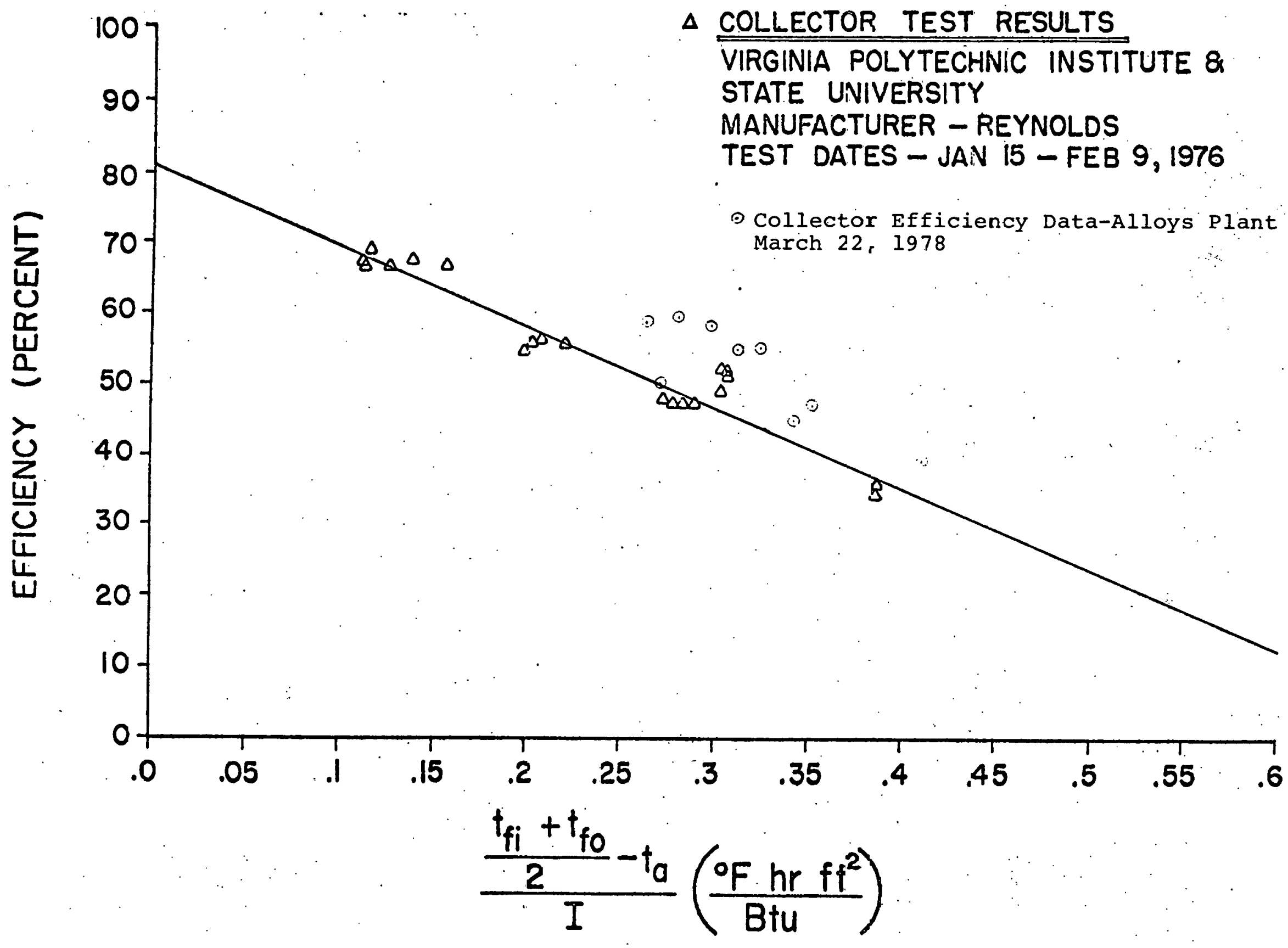




\title{
INTERIM PERFORMANCE CRITERIA
}

\author{
CERTIFICATION
}

CONTRACT NO. G-77-A-01-4070

DEMONSTRATION CONTRACTOR REYNOLDS METALS COMPANY

SYSTEM LOCATION LISTERHILL, ALABAMA

SYSTEM TYPE SPACE HEAT AND HOT WATER

We have addressed each of the items referenced in NASA publication $98 \mathrm{M} 10001$ entitled "Interim Performance Criteria For Heating/ Cooling systems and Facilities" dated February 28, 1975. It is our opinion that the subject system complies with these performance criteria. Due to limitations in the state-of-the-arts, some of the criteria were evaluated on the basis of professional judgement and/or experience in lieu of quantitative analysis and test data.

DATE 


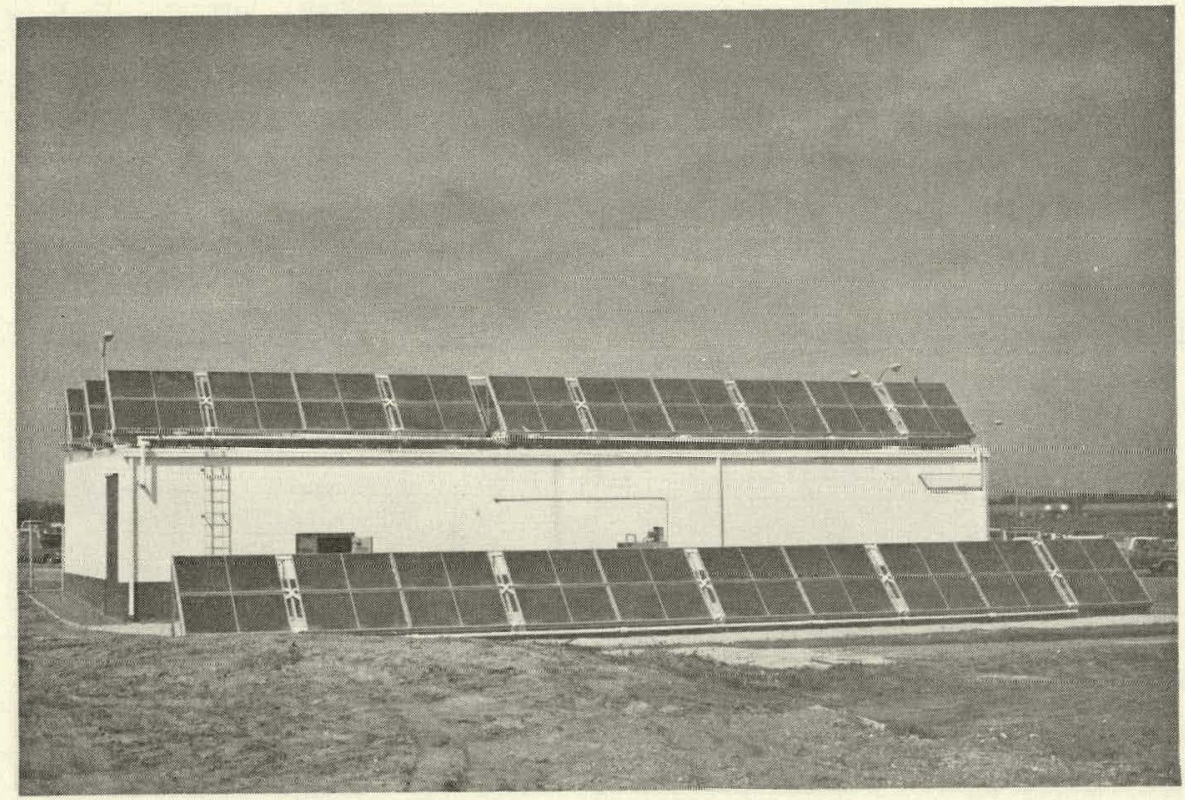

COMPLETED INSTALLATION UN SHOWER AND CHANGE FACILITY

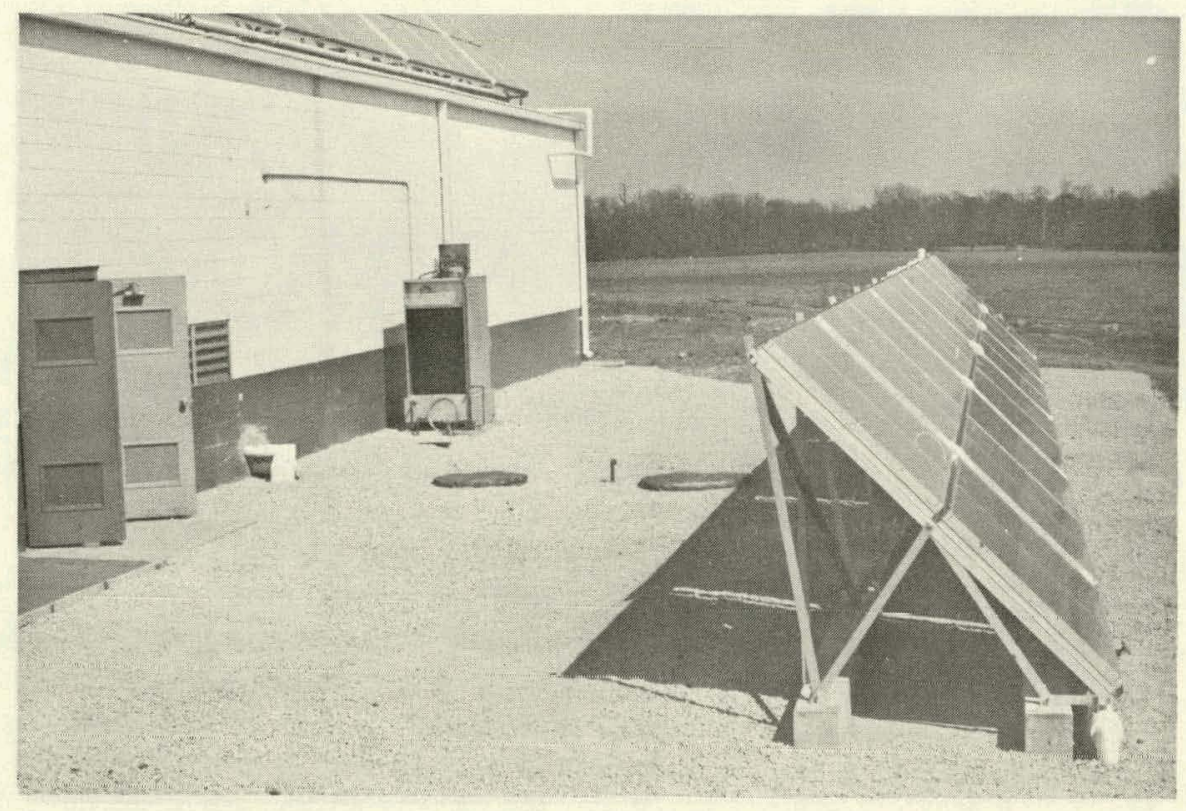


$-41-$

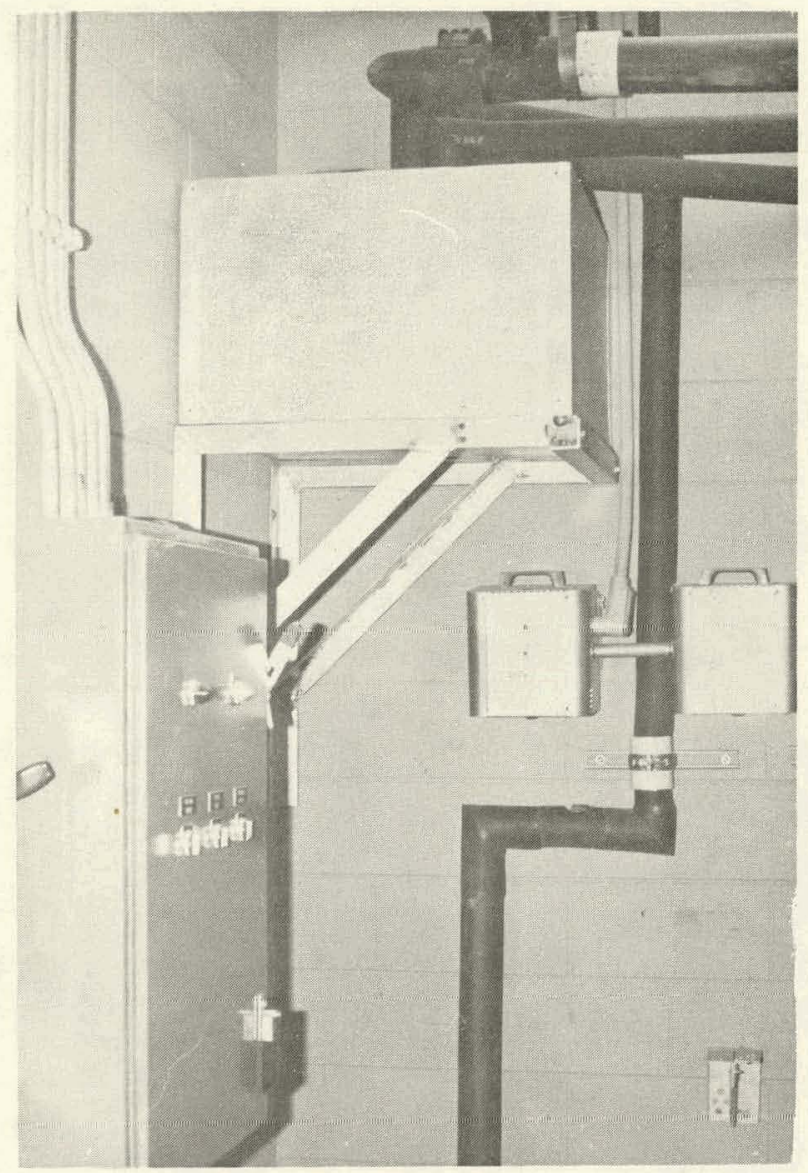

SYSTEM CONTROL PANEL AND

HEAT DUMP HEAT EXCHANGER

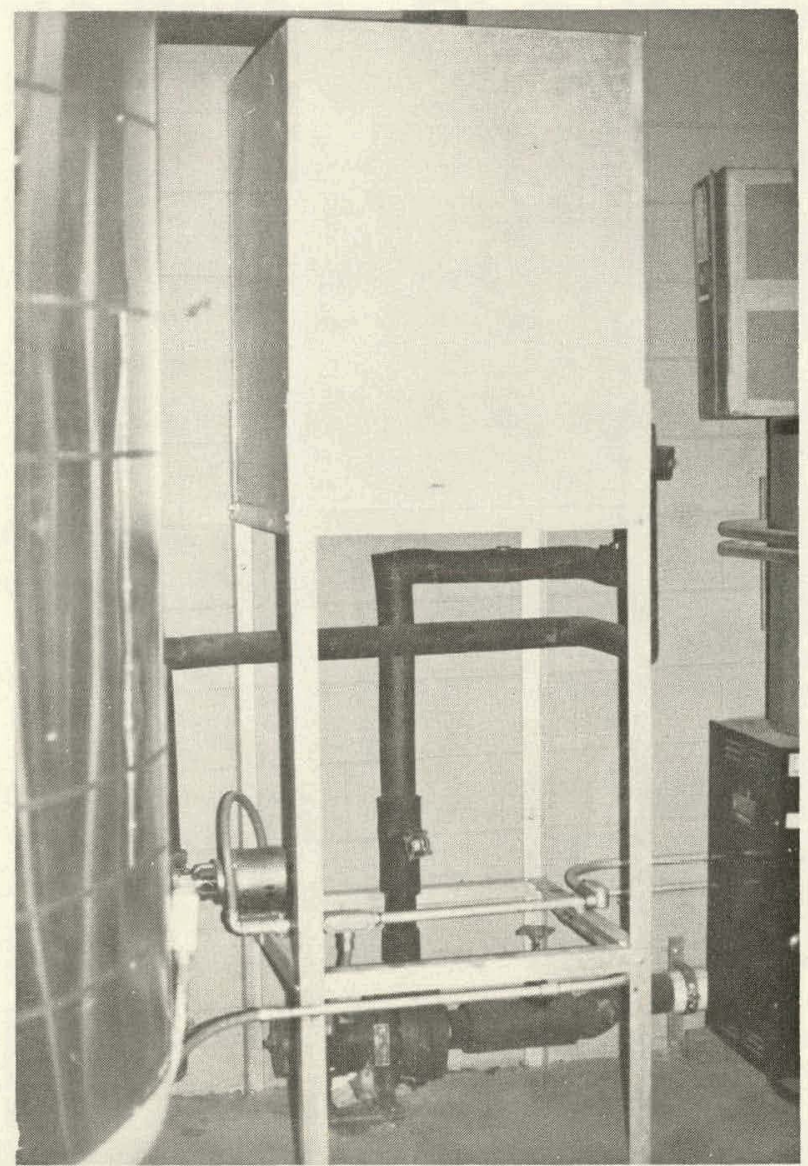

POTABLE WATER HEAT EXCHANGER 


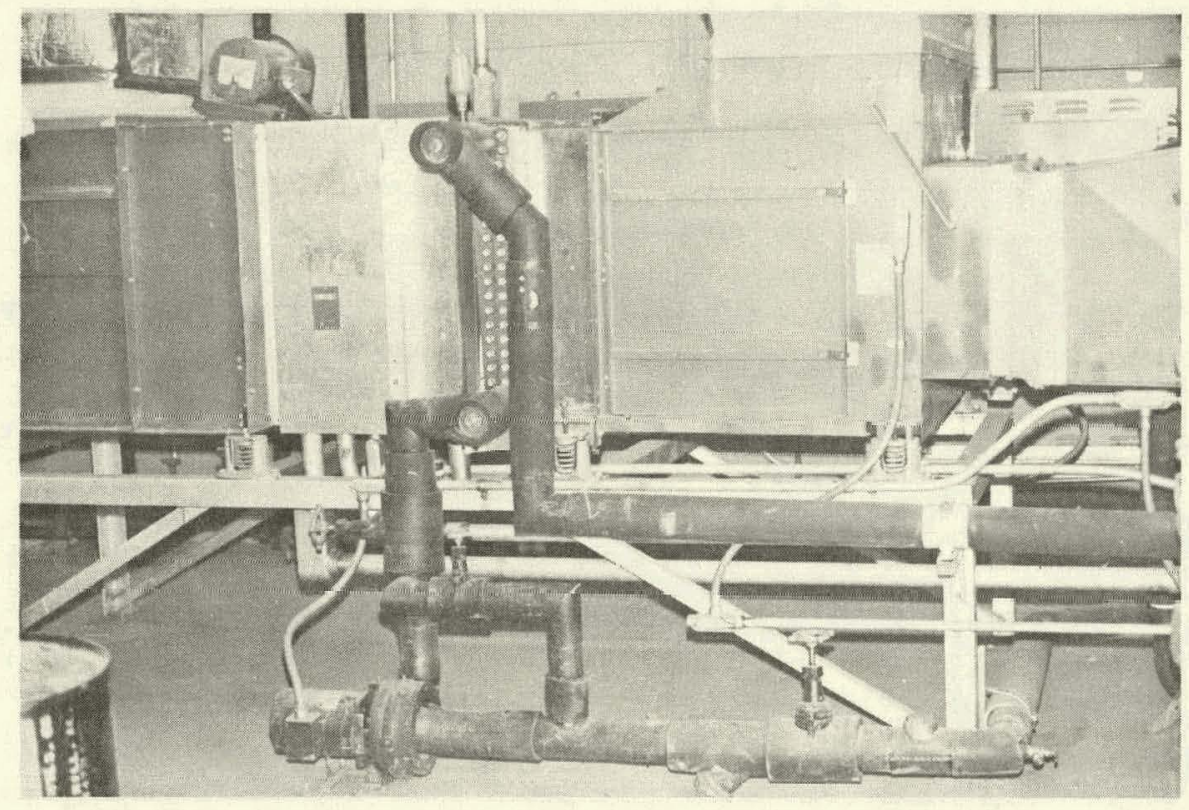

SPACE HEAT SUBSYSTEM

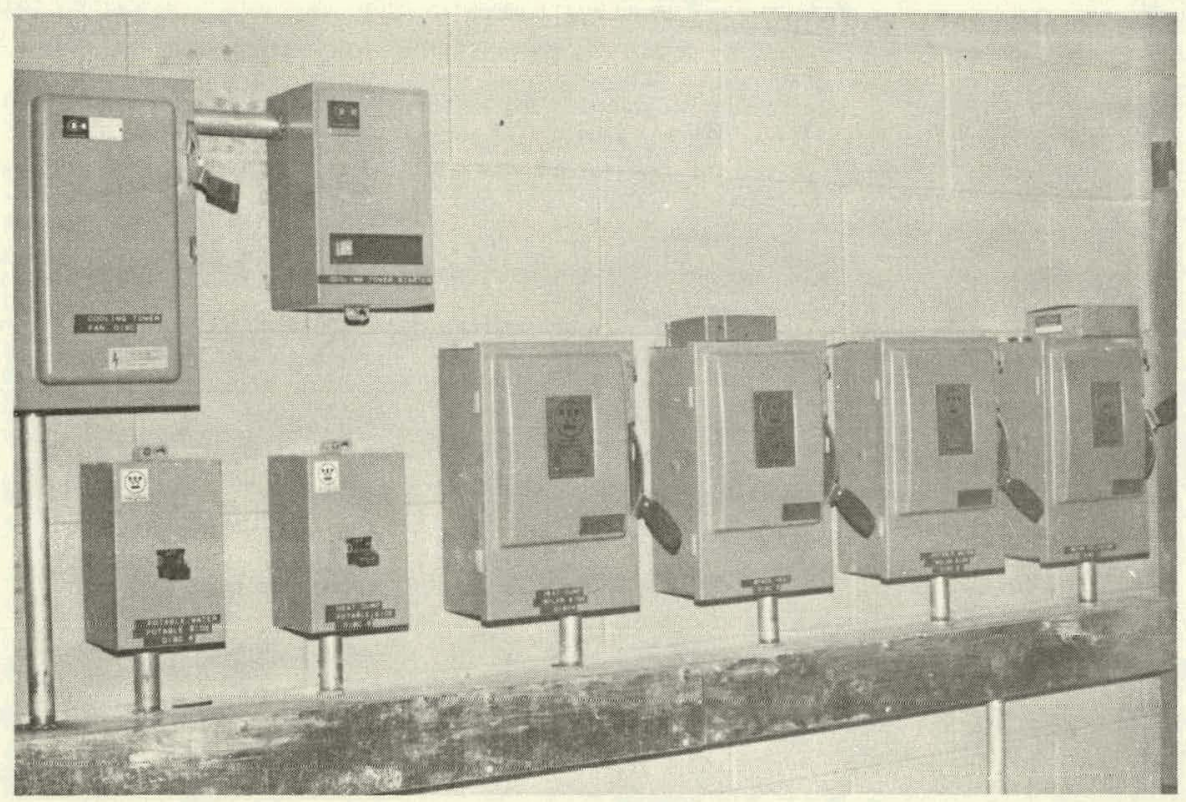




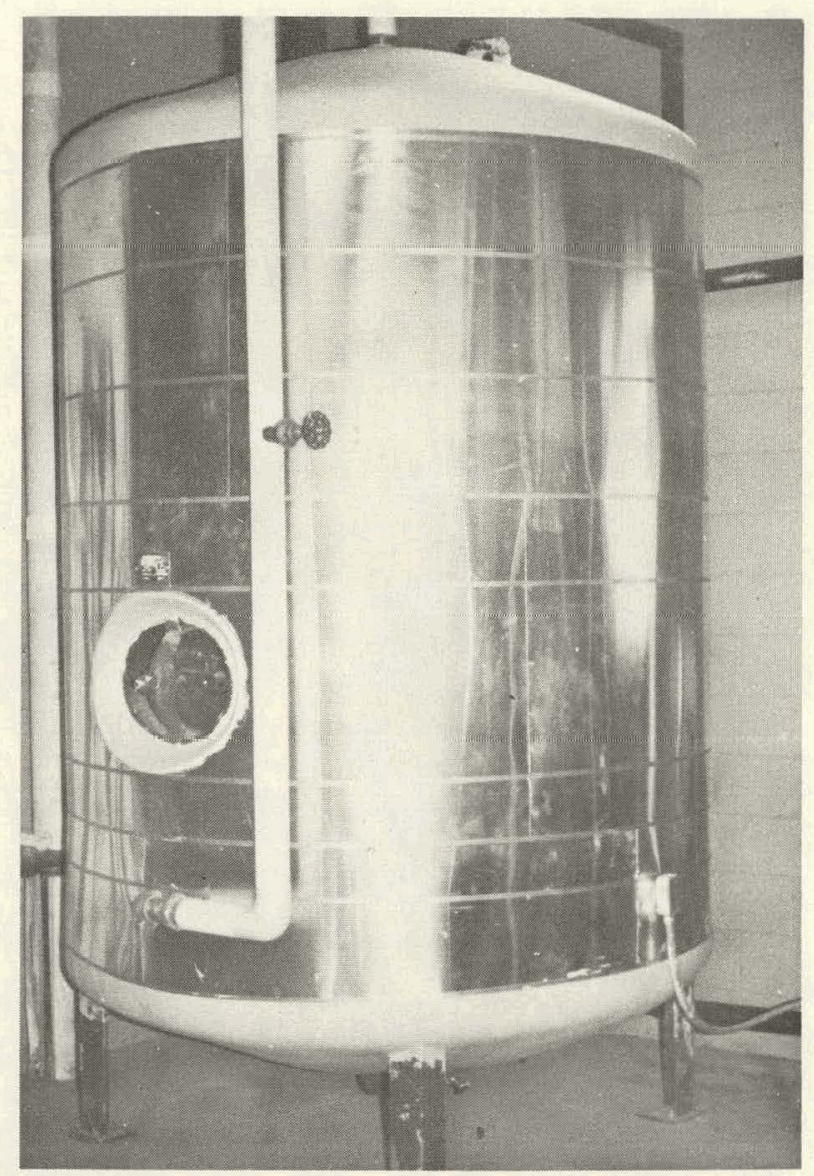

1400 GALLON POTABLE WATER STORAGE TANK 
$-44-$

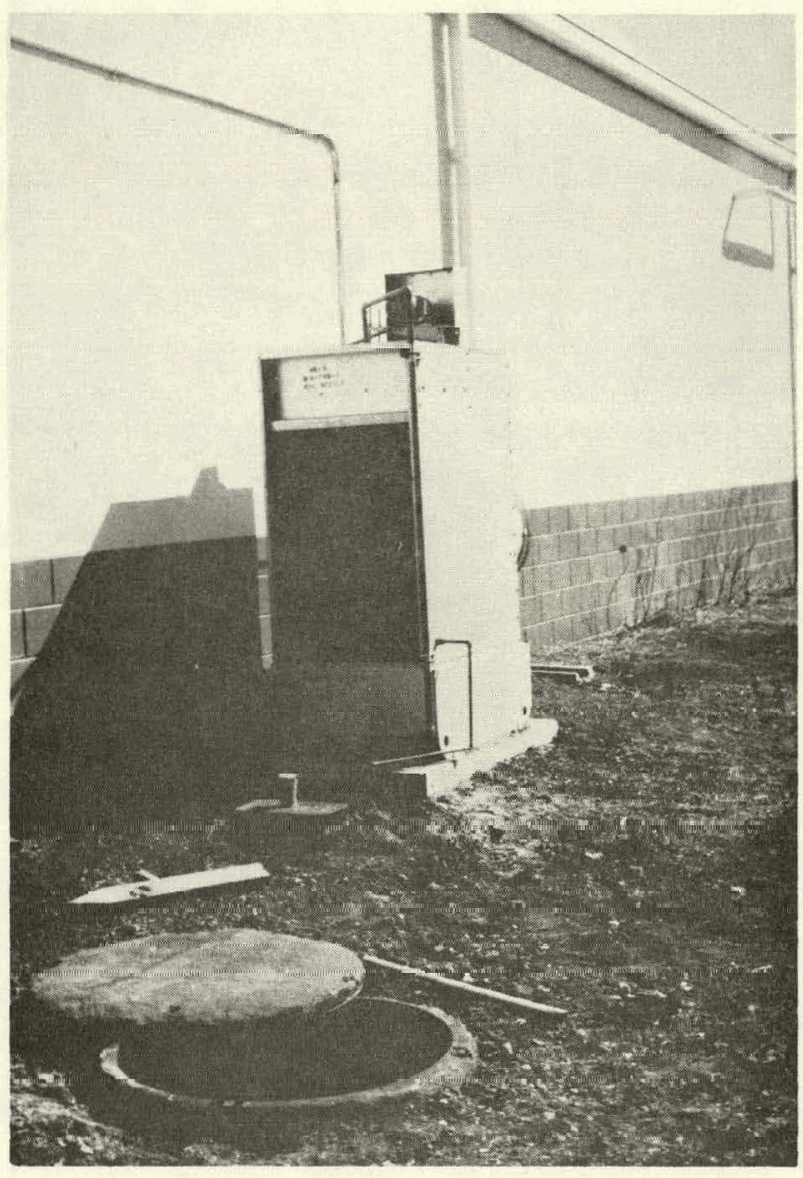

COOLING TOWER 



\section{START-UP PROCEDURE}

(Reference RMCo Dwg. No. 45616107R)

1.0 Add inhibitor to solar storage water - The water in the solar storage tank will be charged initially with 4 fluid ounces of NALCO 2755 per gallon of water.

1.1.1 Gloves and goggles should be worn when adding the inhibitor to the solar water.

1.1.2 Determine the volume of water in solar storage tank. Refer to Appendix G.

1.1.3 Add inhibitor at a rate of 4 fluid ounces per gallon of storage water.

2.0 Check to see that all six pump disconnect switches are open.

3.0 Set all controllers (1TC, 2TC, and $3 \mathrm{TC}$ ) on OFF position and adjust cut-in set point to desired temperature differential. (Instructions for checking the operation of the controller and the sensors are shown in the Solar Commander Installation Instruction in Appendix A).

\subsection{Solar Collector Loop}

3.1.1. Set the solar collector loop controlier (1TC) on a $15^{\circ} \mathrm{F}$ differential by aligning the white tip of the screwdriver slnt (in the circular shaped potentiometer) with the white dot at the 3-0'clock position (The potentiometer is normally set on the white dot or $15^{\circ} \mathrm{F}$ set point).

\subsection{Potable Hot Water Subsystem}

3.2.1 Set the potable hot water controller (2TC) on an $80 \mathrm{~F}$ temperature differential by setting the white tip of the screwdriver slot at the 10-o'clock position.

\subsection{Space Heat Subsystem}

3.3.1 Set the space heat controller (3TC) on a 150F temperature differential using the procedure described in section 3.1.1. 
4.0 Set the thermostats (1TAS, 2TAS, and 3TAS) to the desired temperatures.

4.0.1 Minor adjustments may be required to obtain better set point accuracy after installation. (For instructions, refer to Installation and Maintenance Instructions for Remote Bulb Temperature Controllers, Appendix B.)

\subsection{Potable Water Subsystem}

4.1.1 Set thermostat (1TAS) by turning dial knob to $60^{\circ} \mathrm{F}$.

\subsection{Space Heat Subsystem}

4.2.1 Set thermostat (2TAS) by turning dial knob to $2^{\circ} \mathrm{F}$ higher than thermostat setting for the back-up space heating system.

\subsection{Heat Dump Subsystem}

4.3.1 Set thermostat (3TAS) by turning dial knob to $185^{\circ} \mathrm{F}$.

5.0 close main switch on main power control panel (This switch will usually be closed).

6.0 Close bus switch (10) on main power control panel to energize controls.

7.0 Check control panel door (A safety switch prevents the system from starting until control panel door is closed and latched).

8.0 Check all pumps for prime, and prime if needed (All pump disconnect switches should be open). PUMPS SHOULD NEVER BE STARTED OR RUN DRY (See Pump Operating and Maintenance Instructions in Appendixes $C, D$, and E). Circulating pumps should be oiled before running (See Appendix E).

\subsection{Solar Loop Pump}

8.1.1 Attached garden hose to boiler drain in supply line.

8.1.2 Close pump discharge valve.

8.1.3 Fill supply line with tap water. 
8.1.4 Vent supply line at pump by loosening vent plug in pump. It may also be necessary to loosen union nearest tank in supply line.

8.1.5 Close boiler drain.

8.1.6 Partially open discharge valve.

8.1.7 Start pump by setting controller switch (ITC) On MANUAL and close pump disconnect switch (IDISC). DO NOT START SOLAR LOOP PUMP WHEN OUTSIDE TEMPERATURE IS BELOW $32^{\circ} \mathrm{F}$ AND SUN IS NOT SHINING.

8.1.8 Check flow at florater valve by removing one of the brass caps and pressing valve in with small sripewdriver.

8.1.9 If pump not primed, repeat steps 8.1 .2 through 8.1.8.

8.1.10 Open discharge gate valve as soon as pump reaches operating speed.

8.1.11 Turn water off and disconnect garden hose.

8.1.12 Shut pump off after priming by opening disconnect switch (DISC1). Set controller switch on OFF position.

8.2 Space Heat, Potable Water and Heat Dump Solar Pumps

(For additional information, refer to Appendix D).

8.2.1 Attach garaen hose to boiler drain in supply line (near main power panel).

8.2.2 Close valves in space heat and potable water discharge lines.

8.2.3 Close valve in solar supply line for heat dump pump.

8.2.4 Fill supply line with tap water.

8.2.5 Vent space heat and potable.water pump by opening vent plug on top of each pump. Vent heat dump pump through plug in tee near pump.

8.2.6 Close boiler arain.

8.2.7 Partially open all pump discharge valves and open heat dump supply valve. 
8.2.8 Start pumps individually on solar side of each subsystem.

8.2.8.1 Potable Hot Water Subsystem Set switch (SSI) in control panel on HAND; set controller switch (2TC) on MANUAL; and close pump disconnect switch (2DISC) .

8.2.8.2 Space Heat Subsystem - Set switch (SS2) in control panel. on HAND; set controller (3TC) switch on MANUAL; and close pump disconnect switch (3DISC).

8.2.8.3 Heat Dump Subsystem - Set switch (SS3) in control panel on HAND and close pump disconnect switch (4DISC).

8.2.9 Check flow at florater valve in potable water and space heat subsystem. Check flow in heat dump subsystem by noting temperature change at pump or check valve above pump.

8.2.10 Open discharge gate valve as soon as pump reaches operating speed.

8.2.11 Shut each pump off after priming by opening respective disconnect switches. Set all controller switches on OFF position.

8.3 Circulating Pump for Potable Side of Potable Water Subsystem - (For additional information, refer to Appendix E).

8.3.1 Oil all three oil cups before starting circulator and every three months thereafter (Use S.A.E. \#20 non-detergent oil).

8.3.2 Check to be sure circulating loop is filled with tap water.

8.3.3 Start circulating pump by setting switch (SSI) in control panel on HAND; set controller (2TC) switch on MANUAL; and close pump disconnect (6DISC).

8.3.4 Shut pump off by opening disconnect switch (6DISC). Set controller switch (2TC) on OFF position. 
8.4 Pump for Potable Side of Cooling Tower Subsystem - (For additional information, refer to installation and operation instructions for Bell \& Gossett 1535 pump in Appendix C).

8.4.1 Check to be sure circulating loop is filled with tap water (See section 9.0 for filling cooling tower reservoir).

8.4.2 Start pump by setting switch (SS3) in control panel on HAND and close pump disconnect switch (5DISC).

8.4.3 Shut pump off by opening disconnect switch (5DISC). Set switch SS3 in control panel on OFF.

9.0. Clean cooling tower and fill with tap water.

9.1.1 Wash foreign matter from fill and basin.

9.1.2 Fill circulating system with water.

9.1.3 Adjust float valve to maintain 5" of water in cold water basin.

9.1.4 Check bleed-off line to make sure water is being discharged during operation.

9.1.5 Check fan for free rotation and oil level in bearing housing (See Appendix F). start motor and check direction of rotation. Fan must rutate clockwise when viewed from the fan discharge side. If the rotation is incorrect, change any two of the three motor leads.

9.1.6 Depth of water in hot water basin should be uniform. If the basin overflows, reduce the flow rate. Do not pump more water than design capacity.

9.1.7 WARNING: Do not cycle the motor so that the total of the starting time exceeds 30 seconds each hour. 
10.0 Check operation of each subsystem manually.

\subsection{Check Solar Collector Loop}

10.1.1 Check solar loop pump (1MTR) for prime. (DO NOT START SOLAR LOOP PUMP WHEN OUTSIDE TEMPERATURE IS BELOW $32^{\circ} \mathrm{F}$ AND SUN IS NOT SHINING).

10.1.2 Check for proper operation of normally open solenoid valve in by-pass line near underground solar storage tank. Solenoid valve (ISOL) must close when power is on to pump. (See Appendix H.)

10.1.3 Set switch of solar loop controller (1TC) on MANUAL. Start solar loop pump by closing pump disconnect switch (IDISC).

10.1.4 Using Thrush Model 832 Florater meter and Thrush Florater balancing valve, check to see if flow rate is balanced to each collector array. If not, set flow rate on ground mounted collectors by adjusting Florater balancing valve (Optimum flow 10 to 13 . gpm).

10.1.4.1 Open carrying case and place test kit in a convenient spot on test site with test kit horizontal.

10.1.4.2 with test kit balance valve closed, connect hoses to florater - Red hose upstream, high pressure -- Green hose downstream, low pressure.

10.1.4.3 Open test kit balance valve.

10.1.4.4 Open high and low bleed valves alternately to purge air from system (Bleed water discharges from convenient clear plastic flexible tube).

10.1.4.5 When bleeding shows all air removed, close test kit balance valve and read differential pressure gauge. Refer to chart in Appendix I for conversion to gpm and additional instructions. 
10.1.4.6 When test is complete, open test kit balance valve and disconnect test hoses from florater.

10.1.4.7 Store hoses by coiling them around the test kit panel.

10.1.5 Check and/or set florater on each bank of roof mounted collectors using the above procedure. (Optimum flow 10 to $13 \mathrm{gpm}$ per collector array.)

10.1.6 Recheck flow on ground mounted collectors and adjust if needed.

10.1.7 Repeat 10.1.4, 10.1.5, 10.1.6 until flows approximately equal.

10.1.8 If florater setting over 50, open pump (IMTR) by-pass valve slightly.

10.1.9 Repeat 10.1 .7 and 10.1 .8 until flows are equal and at desired rate and florater is operating in lower range.

10.1.10 Shut off pump by opening disconnect switch (IDISC).

10.1.11 Move switch of solar loop controller (ITC) to OFF position.

10.2 Check Potable Hot Water Subsystem

10.2.1 Set controller (2TC). switch on MANUAL.

10.2.2 Set switch (SSI) in control panel on HAND position and close pump disconnect switches (2DISC and 6DISC). CHECK PUMPS FOR PRIME BEFORE ATTEMPTING TO START PUMPS.

10.2.3 If pumps fail to run, refer to troubleshooting section.

10.2.4 To shut off system, open pump disconnect switches (2DISC and 6DISC) and place controller (2TC) switch on OFF position.

\subsection{Check Space Heat Subsystem}

10.3.1 Set controller (3TC) switch on MANUAL.

10.3.2 Shut off back-up space heating system if weather permits. 
10.3.3 Set switch (SS2) in control panel on HAND position and close pump disconnect switch (3DISC). CHECK PUMP FOR PRIME BEFORE ATTEMPTING TO START PUMP.

10.3.4 If pump does not run, refer to troubleshooting section.

10.3.5 To shut off system, open pump disconnect switch (3DISC) and place controller (3TC) switch on OFF position.

10:4 Check Heat Dump Subsystem - DO NOT OPERATE COOIING TOWER LOOP PUMP WHEN OUTSIDE TEMPERATURE IS BELOW $32^{\circ} \mathrm{F}$.

10.4.1 Check to see that cooling tower is filled with water and operating properly (See Section 9.0).

10.4.2 Set switch (SS3) in control panel on HAND position and close pump disconnect switches (4DISC and 5DISC). CHECK PUMPS FOR PRIME BEFORE ATTEMPTING TO START PUMPS.

10.4.3 Tf pumps do not run, refer to troubleshooting section.

10.4.4 Shut off system by opening disconnect switches (4DISC and 5DISC) on respective pumps.

11.0 Operate each subsystem individually on automatic mode.

\subsection{Solar Collector Loop}

11.1.1 Set controller (1TC) on AUTOMATIC position (For pumps to operate automatically, temperature of collector must be $15{ }^{\circ} \mathrm{F}$ higher than temperature of solar water).

11.1.2 close pump disconnect switch (IDISC).

11.1.3 If system fails to operate, refer to troubleshooting section.

11.1.4 Shut system off by opening pump disconnect switch (IDISC) and setting controller (ITC) on OFF position. 


\subsection{Potable Hot Water Subsystem}

11.2.1 Turn thermostat (ITAS) down as low as possible.

11.2.2 Set switch (SSI) in control panel and "on controller (2TC) on AUTOMATIC position (Temperature of solar water must be 150F higher than temperature of potable water, and ambient temperature must be above setting of thermostat (ITAS) for pumps to operate automatically).

11.2.3 Close pump disconnect switches (2DISC .. and 6DISC).

11.2.4 If system fails to operate, refer to troubleshooting section.

11.2.5 Shut system off by opening pump disconnect switches (2DISC and 6DISC) and setting ambient thermostat (ITAS) on $60^{\circ} \mathrm{F}$.

\section{3 Space Heating Subsystem}

11.3.1 Increase thermostat (2TAS) setting (in locker room) until system calls for heat.

11.3.2 Set switch (SS2) in control panel and on controller (3TC) on AUTOMATIC position.

11.3.3 Shut off back-up space heating if weather conditions permit.

11.3.4 Close pump disconnect switch (3DISC).

11.3.5 If system fails to operate, refer to troubleshooting section.

11.3.6 Shut off pump by opening pump disconnect switch (3DISC).

11.3.7 Restore system to normal operating condition.

\subsection{Heat Dump Subsystem}

11.4.1 Set switch (SS3) in control panel on AUTOMATIC position.

11.4.2 Turn thermostat (3TAS) down as low as possible. 
11.4.3 Close pump disconnect switches (4DISC and 5DISC).

11.4.4 If system fails to operate, check to be sure that thermostat ( 3 TAS) setting is lower than temperature of solar water. Also, refer to troubleshooting section.

11.4.5 Shut system off by opening pump disconnect switches (4DISC and 5DISC) and reset thermostat (3TAS) at $185^{\circ} \mathrm{F}$.

12.0 Set system up for automatic operation.

12.1 Set all switches (SSl, SS2, and SS3) in control panel on AUTOMATIC.

12.2 Set all controllers (1TC, 2TC, and 3TC) on AUTOMATIC.

12.3 Set all thermostats (1TAS, 2TAS, and 3TAS) in accordance with Section 4.0.

12.4 Close all pump disconnect switehes. 
OPERATING AND MAINTENANCE INSTRUCTIONS

1.0 Inhibitor - Both periodic and annual additions of the NALCO 2755 inhibitor are required to the solar storage water (Refer to section 1.0 of Start-up Procedure for initial charge of inhibitor).

\subsection{Handling Inhibitor}

1.1.1 Gloves and goggles should be worn when adding the inhibitor to the solar water.

1.2 Monitoring

1.2.1 Read make-up water meter monthly and add 4 fluid ounces of NALCO inhibitor for each gallon of tap water added to system (Refer to section 1.1 for handling precautions).

1.2.2 Check pH once a month with Litmus paper or a $\mathrm{pH}$ probe. $\mathrm{pH}$ should be maintained between 10.0 and 10.5 . If $\mathrm{pH}$ falls outside of this range, a sample should be taken and forwarded to MRD for analysis (See section 1.2.3).

1.2.3 Take a 150 to $200 \mathrm{ml}$ sample from solar storage tank every six months and forward to Reynolds Metallugical Research, Corrosion Laboratory, in Richmond, Virginia for $\mathrm{pH}$, resistivity and concentration analysis (Solar water should be thoroughly mixed before sampling).

1.2.4 Solar storage water is to be recharged annually with 2 fluid ounces of NALCO 2755 inlibitur per gallon of solar water. (Existing solar water does not have to be drained.)

2.0 Pumps

2.1 Centrifugal - Refer to Appendix $C$ and Appendix D.

2.2 Circulator - Oil all three cups with SAE 20 inon-detergent oil before starting pump initially and every 3 months thereafter. For additional instructions, refer to Appendix E.

\subsection{Strainers}

3.1 All cast, iron Y-type strainers are to be cleaned monthly. for the first six months and every three months thereafter. 


\subsection{Collector Repair}

\subsection{Outside Glazing}

4.1.1 Small breaks or punctures may be repaired by covering the damaged area with a patch of the glazing material and bonding with a RTV silicon sealant or with Scotch pressure sensitive adhesive transfer tape (No. 465).

4.1.2 The entire outside glazing may be replaced.

4.1.2.1 Remove bottom circumferential row of screws (two in each corner and one midway of top and bottom angle) from angle cover.

4.1.2.2 Remove angle cover from top of collector.

4.1.2.3 Remove old glazing and sealing residue from rectangular glazing frame.

4.1.2.4 Apply Scotch pressure sensitive adhesive transfer tape (No. 465) around the entire perimeter of the glazing frame.

4.1.2.5 Stretch glazing material over the rectangular glazing frame as tight as possible, smoothing out all wrinkles and air pockets while securing glazing. to tape (The $4 \mathrm{mil}$ Tedlar* glazing material may be purchased from most duPont plastic distributors).

4.1.2.6 Apply a small bead of RTV silicon sealant around the perimeter of the angle frame cover.

4.1.2.7 Replace angle frame cover over glazing and secure with screws removed in $4.1 .2: 1$

\subsection{Inner Glazing}

4.2.1 Damaged inner glazing can be replaced using the procedure described in section 4.1 .2 with the exception that the glazing is applied to the bottom of the rectangular glazing frame. The inner glazing is a duPont 1 mil FEP Teflon* $100 \mathrm{~A}$ material and can be purchased from most duPont plastic distributors.

\footnotetext{
* duPont registered trademark.
} 


\section{3 Back of Collector}

4.3.1 Punctures and tears in the back of the collector

can be repaired with Reynolok* Patching Tape.

4.3.1.1 Clean area to be patched with mineral spirits, Varsol, alcohol or naptha.

4.3.1.2 Fill puncture with butyl caulking if needed.

4.3.1.3 Remove paper backing from patching tape and apply tape over damaged area, smoothing out wrinkles and air pockets to insure good adhesion.

\subsection{Cooling Tower}

\subsection{Maintenance Instructions}

5.1.1 Lubricate motor periodically and at start and end of each season.

5.1.2 Keep oil cups full to insure proper oil level in bearing housing (Use SAE 20 mineral oil).

5.1.3 Check belt tension every two to three weeks during peak operation season.

5.1.4 Check the bleed-off for continuous water discharge.

5.1.5 Drain and clean cold water basin and suction screen periodically.

5.1.6 Check float valve periodically for proper operation and maintenance of water level.

5.2 Seasonal Shutdown - Between October 1 and May 1, the cooling tower is to be shut down and drained to prevent damage from freezing.

5.2.1 Close stop and waste valve in supply line and open vent.

5.2.2 Open all valves in plastic vault at foot of tower.

5.2.3 Drain tower basin and leave the basin drain open.

5.2.4 Remove and store belts in a cool, dark, dry place. clean and coat sheave grooves with rust preventive.

\footnotetext{
* Reynolds registered trademark
} 
5.2.4 At shutdown, operate tower until oil in bearing housing is warm; drain and refill with SAE 20 mineral oil.

5.2.5 Lubricate fan motor.

\subsection{Seasonal Start-up}

5.3.1 Remove rust preventive from sheaves and replace belt (Refer to page 4 of Appendix $F$ for belt installation and tensioning instructions).

5.3.2 Check to see that fan is free to rotate before starting motor. Check fan for proper rotation (clockwise when viewed from fan discharge side). Lubricate fan motor.

5.3.3 Operate tower until warm drain bearing housing and refill with SAE 20 mineral oil.

5.3.4 Clean and wash foreign matter from fill and basins.

5.3.5 Fill circulating system with tap water.

5.3.6 Start pump and adjust float valve to maintain 5 " of water in cold water basin.

5.3.7 Check bleed-off line to make sure water is being discharged during operation.

5.3.8 Check depth of water in hot water basin. If basin overflows, reduce flow rate. 
TROUBLE SHOOTING

(Reference RMCo. Dwg. No. 45616107R)

1.0 Power

1.1. Control Panel

PROBLEM: THERE IS NO POWER TO PANEL

POSSIBLE CAUSE

(a) Open bus switch (10) on main control panel

(b) Blown fuse (13FU)
REMEDY

(a) Close swileil.

(b) Replace fuse. If fuse blows again; have an elert.rician check electrical circuit.

1.2 Solenoid Valve

PROBLEM: SOLENOID VALVE (ISOL) DOES NOT CLOSE WHEN PUMP (IMTR) IS ENERGIZED

POSSIBLE CAUSE

(a) Malfunctioning starter
(1M)

(b) Coil burned out
REMEDY

(a) Check starter reset

(b) Check electrical continuity and replar.e coil if needed.

\subsection{Pumps}

2.1 Solar Collector Loop Pump

PROBLEM : PUMP. (IMTR) WILL NOT RUN

POSSIBLE CAUSE
(a) Open or faulty disconnect switch (IDISC)

(b) Blown fuse (1FU, 2FU, or $3 \mathrm{FU}$ )

\section{REMEDY}

(a) Check disconnect switch.

(b) Replace fuses. If fuse blows again, have an electrician check electrical circuit. 
(c) Heater overload in starter (1M)

(d) Open circuit in motor starter

(e) Temperature differential between collector and solar water in storage tank is less than cut-in differential setting on solar controller (ITC)

(f) Malfunctioning solar controller (ITC)

(g) Malfunction of controller (ITC) sensors

(h) Temperature of water in solar storage tank may be above $190^{\circ} \mathrm{F}$ (c) Wait a few minutes and reset. If motor still inoperable, check for electrical continuity with ohmmeter.

(d) Check for loose connection and dirty or burned contacts. Check for electrical continuity with ohmmeter (Replace defective parts).

(e) Check to see that controller is on and set, in accordance with section 3.1 of Start-up Procedure. Then wait for temperature of collector to increase or temperature of solar water to decrease.

(f) Check automatic operation of module in accordance with section A. 6 of Solar Controller Installation Instructions in Appendix $A$.

(g) Check sensors in collector and solar storage tank in accordance with Section B.l of Solar Controller Instructions in Appendix A.

(h) Check temperature of water in solar storage tank. If above $1900 \mathrm{~F}$ wait for solar water to cool. 
PROBLEM: PUMP (IMTR) RUNS CONTINUOUSLY

\section{-POSSIBLE CAUSE}

(a) Controller (ITC)

set improperly

(b) Malfunction of controller (ITC) sensors
REMEDY

(a) Check controller for proper setting (Pump will run continuously On MANUAL).

(b) Check sensor in solar collector and solar storage tank in accordance with section A. 6 of Solar Controller Installation Instructions in Appendix A.

\subsection{Potable Water}

PROBLEM: PUMPS (2MTR AND 6MTR) WILL NOT RUN

POSSIBLE CAUSE

(a) Open or faulty
disconnect switch
(2DISC and 6DISC)

(b) Blown fuse (4FU, 5FU, $6 \mathrm{FU}$, or $15 \overline{\mathrm{FU}})$

(c) Heater overload in starter (2M)

(d) Heater overload in starter (6MS)

(e) Temperature differential between solar water in storage tank and potable water in 1400 gallon tank is less than cut-in differential setting on solar controller (2TC)
REMEDY

(a) Check disconnect switch.

(b) Replace blown fuses. It tuse blows again, have electrician check circuit.

(c) Wait a few minutes and reset. If motor still inoperable, check for electrical continuity with ohmmeter.

(d) Replace heater coils for overload relay if needed.

(e) Check to see that controller is on and set in accordance with Section 3.2 of Start-up Procedure. Then wait for temperature of solar water in storage tank to increase or temperature of potable water storage to decrease. 
(f) Malfunctioning solar controller (2TC)

(g) Malfunction of controller (2TC) sensors

(h) Outside air temperature is below limit setting on thermostat (ITAS)

(i) Thermostat switch (1TAS) not operating properly (f) Check automatic operation of module in accordance with Section A. 6 of Solar Controller Installation Instructions in Appendix A.

(g) Check sensors in accordance with Section B.l of Solar Controller Installation Instructions in Appendix A.

(h) If thermostat is set in accordance with section 4.1 of Start-up Procedure, wait for ambient temperature to rise above thermostat limit setting.

(i) Refer, to Appendix B.

PROBLEM: PUMPS (2MTR AND 6MTR) RUN CONTINUOUSLY

POSSIBLE CAUSE

REMEDY

(a) Contoller (2TC) set improperly

(a) Check switch for proper setting (Pump will run continuously On MANUAL).

(b) Malfunctioning of controller (2TC) sensor

(b) Check sensors in potable water tank and solar storage tanks in accordance with section B. 1 of Solar Controller Installation Instructions in Appendix A. 


\subsection{Space Heating}

PROBLEM: PUMP (3MTR) WILL: NOT RUN

POSSIBLE CAUSE

(a) Open or faulty disconnect switch (3DISC)

(b) Blown fuse (7FU, 8FU, or 9FU)

(c) Heater overload in starter (3M)

(d) Open circuit in motor starter (3M)

(e) Temperature differential between solar water in tank and heat duct is less than cut-in differential setting on solar controller (3TC)

(f) Malfunctioning solar controller ( $3 \mathrm{TC}$ )

(g) Malfunction of controller (3TC) sensors
REMEDY

(a) Check disconnect switch.

(b) Replace blown fuses. If fuse blows again, have electrician check circuit.

(c) Wait a few minutes and reset. If motor still inoperable, check for elertrical continuity with ohmmeter.

(d) Check for loose connection and dirty or burned contacts. Check for electrical continuity with ohmmeter (Replace defective parts).

(e) Check to see that solar controller is on and set in accordance with Section 3.3 of start-up procedure. Then wait until solar water heats up or temperature in air duct decreases.

(f) Check automatic operation of module in accordance with section A. 6 of Solar Controller in the Installation Instructions in Appendix A.

(g) Check sensors in air duct and in solar storage tank in accordance with Section B.l of Solar Controller Installation Instructions in Appendix A. 
(h) Temperature in locker room above thermostat. (2TAS) setting.

(i) Thermostat switch (2TAS) not operating properly (h) Check to see that. thermostat in locker room is set in accordance with section 4.2 of Start-up Procedure.

(i) Refer to Appendix B.

PROBLEM: PUMP (3MTR) RUNS CONTINUOUSLY

POSSIBLE CAUSE

(a) Controller (3TC) switch set improperly

(b) Malfunctioning of controller (3TC) sensor
REMEDY

(a) Check controller for proper setting (Pump will run continuously on MANUAL).

(b) Check sensor in air duct and solar storage tank in accordance with section B.l of solar controller installation instructions in Appendix A.

\subsection{Heat Dump Loop}

PROBLEM: PUMPS (4MTR AND 5MTR) WILL NOT RUN

\section{POSSIBLE CAUSE}

(a) Open or faulty disconnect switch

(4DISC and 5DISC)

(b) Blown fuse (10FU, 11FU, $12 \mathrm{FU}$, or $14 \mathrm{FU})$

(c) Heater overload in starter (4M)
REMEDY

(a) Check disconnect switches.

(b) Replace blown fuse. If fuse blows again, have electrician check circuits.

(c) Wait a few minutes and reset. If motor still inoperable check for electrical continuity with ohmmeter. 
(d) Heater overload in starter (5MS)

(e) Temperature of water in storage tank below limit setting on thermostat (3TAS)

(f) Thermostat switch (3TAS) not operating properly (d) Replace heater coils for overload relay if needed.

(e) Pump will not operate unless temperature of solar water exceeds limit setting on thermostat. Check to see that thermostat is set in accordance with Section 4.3 of start-up Procedure.

(f) Refer to Appendix B.

PROBLEM: PUMPS (4MTR and 5MTR) RUN CONTINUOUSLY

\section{POSSIBLE CAUSE}

(a) Thermostat (3TAS) set improperly or malfunctioning

\section{REMEDY}

(a) Check thermostat setting in accordance with Section 4.3 of Start-up Procedure. Refer to Appendix B. 
PRODUCT LITERATURE FOR SYSTEM COMPONENTS 
APPENDIX A

SOLAR COMMANDER AND SENSORS
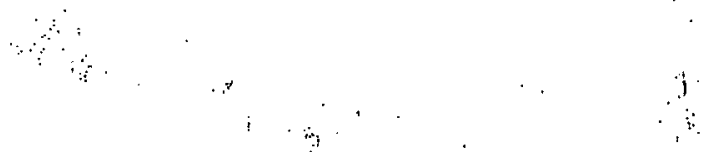

A-ii 


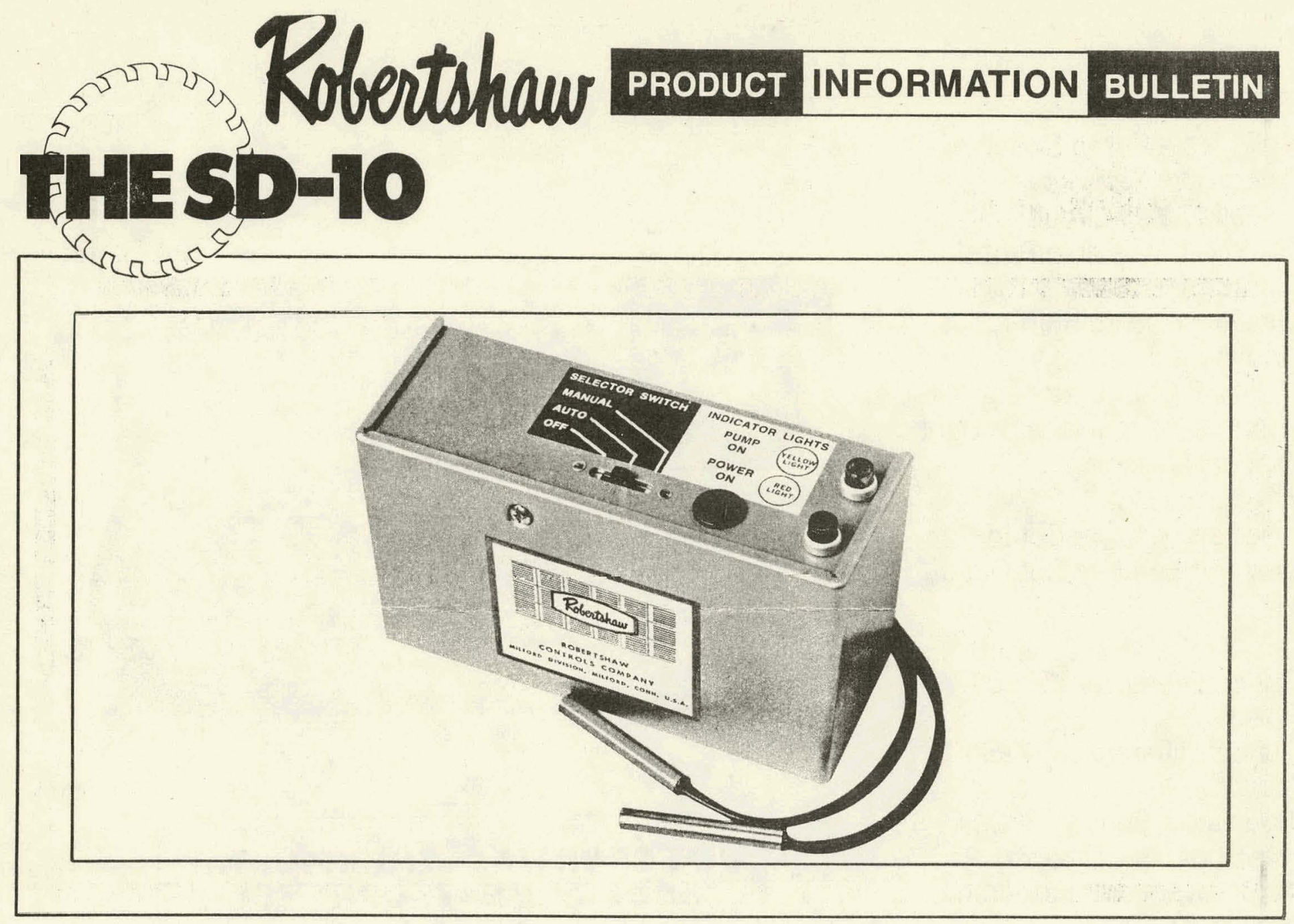

Provides sensitive temperature response and solid state switching to effectively operate a circulating pump in a liquid filled solar heat storage system.

Solid State Thermistor Sensors, of special design, are utilized to accurately signal temperature differential to the control circuit from the solar collector and the storage tank with maximum accuracy from extended distances up to several thousand feet if necessary. The Solar Commander provides pump circulation cut-in any time the collector panel temperature is $15^{\circ}$ higher than the storage tank. Temperature differentials of $5^{\circ}$ or less between these points will signal the solar commander to turn the circulating pump off. The pump switch action is accomplished with solid state components, capable of handling loads up to $3.8 \mathrm{amp}$ inductive, eliminating the need for any moving parts in the controller circuit. The Solar Commander cut-in temperature can be an adjustable option between $8^{\circ}$ and $20^{\circ} \mathrm{F}$.

The Solar Commander circuit incorporates electrical isolation protection for both input and output signal. The entire electrical circuit is protected by space age encapsulation.

The Solar Commander comes equipped with an easy access terminal strip for the low voltage sensor circuit and line leads hook-up. The case-frame is equipped with line lead conduit adapter access. The Solar Commander sensors are conveniently encapsulated in $1 / 4^{\prime \prime}$ copper tubing and come with $12^{\prime \prime}$ lead lengths.
RECEIVED

MAY 31976

ENEINEERING DESIGN SECTIOA 
Solid State Pump Switching

Thermistor Sensors

Encapsulated Circuit

Fixed or Adjustable Pump

Cut-In Differential

Circuit Isolation, Both Input and Output

Power Pilot Indicator Light

Pump Cycling Indicator Light

Manual Switching

High Limit Cut-Out

Low Temperature Cut-In

Low Temperature Cut-Out

UL Approval

Cut-in differential $15^{\circ} \pm 5^{\circ} \mathrm{F}$

(fixed)

Cut-out differential $5^{\circ} \pm 3^{\circ} \mathrm{F}$

(fixed)

Thermistor Sensors $300^{\circ} \mathrm{F}$

rated (interchangeable)

Available without case-frame

and cover

Adjustable cut-in differential ( $8^{\circ}$ to $20^{\circ} \mathrm{F}$ )

Recycling upper limit (190 F)

Positive off lower limit $\left(90^{\circ} \mathrm{F}\right)$

Power Pilot Indicator Light

Pump Cycling Indicator Light

Three position manual

switch (On-Off-Auto)

Two position manual switch

(Off-Auto)

High Temperature Sensors

(400 $\mathrm{F}$ )

Input 80 to 130 volts, 60

cycles $\mathrm{Hz}$

Load - 3.8 amp inductive full

load amperes 29 amp locked rotor

Thermistor Linearity included in control tolerance between $65^{\circ}$ and $1900^{\circ}$

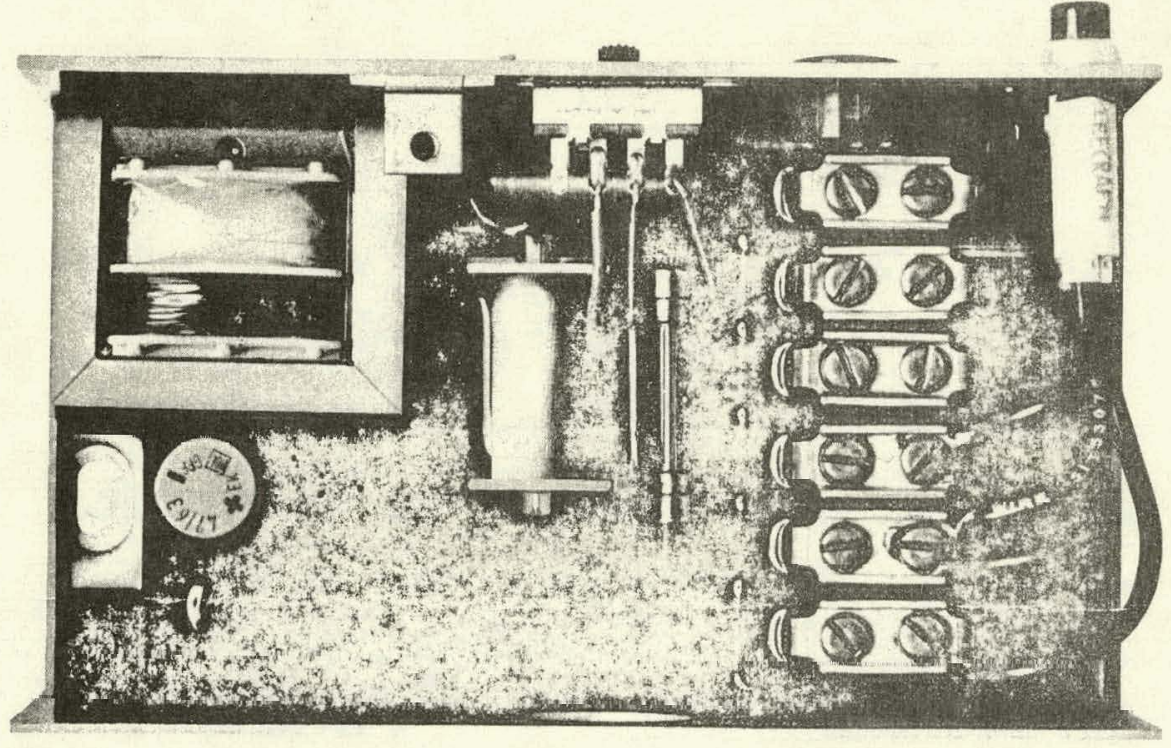

\section{DIFFERENTIAL THERMOSTAT SOLAR HEAT CONTROL $S D=10$}

COLLECTOR PANEL

SENSOR

STORAGE TANK

SENSOR

$120 \mathrm{~V}$. - $60 \mathrm{HZ}$.

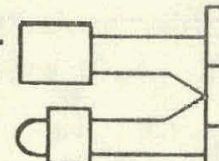

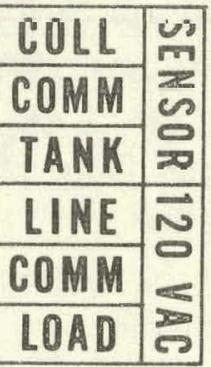

PUMP MOTOR
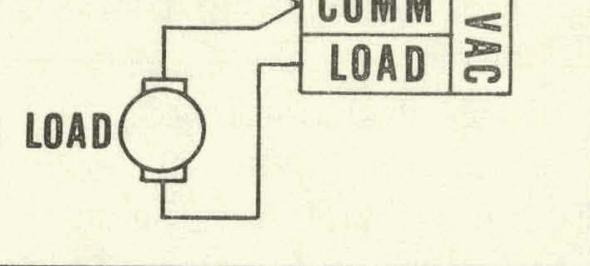
SOLAR COPMIANDER IMSTALLATION INSTRUCTIONS

A. Module instructions apply to that with lights, selector switch, CI and Co diff., hign limit cut-out and freeze protection.

1. Remove the cover and read the label instructions and wiring diagram.

2. Mounting of the control can be made thru the holes in the back of the case. The control is not position sensitive and may be mounted in any plane. Each case has an outlet for high voltage leads accepting $1 / 2^{\prime \prime}$ conduit fittings.

3. All power to the control should be removed prior to wiring. Power supply to terminal is marked "LINE".

4. Connect motor leads to terminals "LOAD and COPHON". The full load ampere rating of the motor nust not exceed 3.8 amps $0120 \mathrm{VAC}, 50 / 60 \mathrm{Hertz}$ (1.9A C240VAC). The control should be used in ambients not exceeding $150^{\circ} \mathrm{F}$ 。

5. Units supplied with the three (3) position selector switch should have the switch in the "off" position prior to closing of power disconnect. With power applied motor will not run. If optional lights are included the red light will be on indicating power to the control. Moving the selector switch to "Manual" will permit the motor and pump to run. The motor will run continuously regardless of sensor condition. With light option, the amber light will be on. Moving the selector switch to "OFF" will turn off the motor and amber light.

6. Checking the automatic operation of the module, prior to connecting the sensors, can be made as follows on all modelsi

a. By jumping the sensor terminals "COLLECTOR" to sensor "COMMON" will permit the motor to operate once the selector switch is moved from the "OFF" to "AUTO" position, checking the cut-in circuit of the module. Remove jumper.

b. With the "TAHK" to "COMHON" jumpered and "COLLECTOR" to sensor "COMRON" opened; when moving the selector switch from "OFF" to "AUTO" the motor will not run. This checks the differential cut-out portion of the module.

Units without a selector switch can be checked similarly to above except (by removal and re-applying the supply voltage. These units are always automatic and can never run constantly.

B. Sensor instructions apply to both $300^{\circ} \mathrm{F}$ and $400^{\circ} \mathrm{F}$ sensors. The sensors as manufactured are for $\mathrm{clamp}$ mounting to their respective sensing surfaces by means of the tubing clip supplied with each sensor. These units must not be immersed into the fluid transfer mediun unless installed in a sensor well.

1. Checking the sensor can easily be made by means of a Multimeter or digital ohmmeter. The color of the leads from the sensor denote the maximum panel temperature $-300^{\circ} \mathrm{F}$ for white and $400^{\circ} \mathrm{F}$ for red. The white $300^{\circ} \mathrm{F}$ sensor is always used in the storage tank, while the red or white may be used at the collector, depending on maximum temperatures encountered. Excessive tibis and temperature above the sensor rating will degrade the sensor shifting its 


\section{calibration.}

Temperature/resistance values are the same for both $300^{\circ} \mathrm{F}$ and $400^{\circ} \mathrm{F}$

Robertshaw type "SS" sensors. Approximate checking resistances run:

\begin{tabular}{rrr}
\multicolumn{2}{c}{ Temperature } & $\begin{array}{c}\text { Resistance } \\
\text { ohms }\end{array}$ \\
${ }^{\circ} \mathrm{F}$ & ${ }^{\circ} \mathrm{C}$ & \\
$32^{\circ}$ & 00 & 105,000 \\
$77^{\circ}$ & $25^{\circ}$ & 30,000 \\
$122^{\circ}$ & $50^{\circ}$ & 10,000 \\
$212^{\circ}$ & $100^{\circ}$ & 1,700
\end{tabular}

These values are to be used as a guide to the operating of the control and not as a calibration check. 
APPENDIX B

AIPENDIX $\mathrm{F}$

REMOTE BULB TEMPERATURE CONTROLLERS

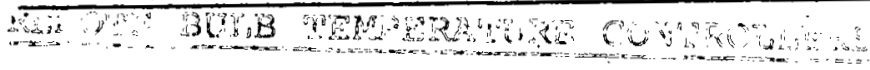

$\mathrm{B}-\mathbf{i}$ 


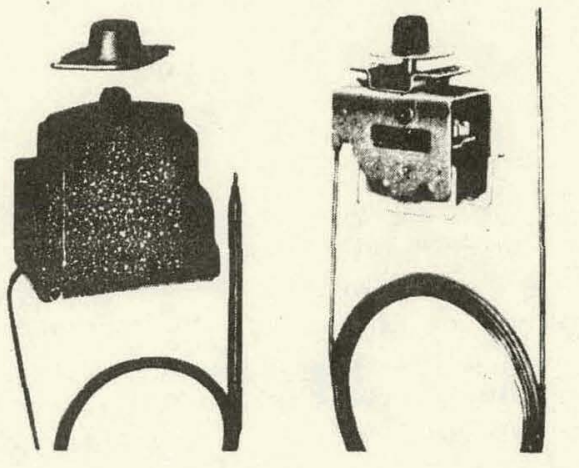

\section{OPERATION}

Temperature variations sensed by the liquid - filled hulb are hydraulically transmilted through the capillary to a stainless steel diaphragm capsule. The capsule operates a lever to actuate one or two snap - action switches.

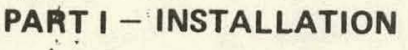

1. Mount the controller in any position. Locate the controller where shock and vibration are minimal. See Fig. 1, mounting dimensions.

a. Panel Mounting (Types E55S and E55AS). Drill panel as shown in figure 1. Mount to panel using two holes on top bracket.

b. Surface Mounting (Types E55 and E55A). Mount using two enclosure mounting holes as shown in figure 1.

2. Install Bulb and Capillary

a. Fully immerse the bulb and 6" capillary in the control zone. For best results it is generally desirable to place the bulb close to (but not touching) the heating or cooling source in order to sense temperature fluctuations quickly.

b. Place the remaining capillary adjacent to the control head so that it will sense the same ambient temperatures.

c. Factory calibration, unless specified otherwise, allows for 6 " capillary tube in the control zone. If longer lengths are required recalibration may be necessary, in which case follow procedures outlined in Part II.

d. " $\mathrm{C}$ " style bulbs can be coiled or shaped to fit the installation. Avoid sharp bends and coils smaller than 2 " radius. Do not bend " $B$ " style bulbs. e. Avoid bending or coiling the capillary tube smaller than $\mathbf{K}^{\prime \prime}$ radius. Exercise caution when making bends near the capillary ends.

f. If a separable well or union connector is used follow. separate instructions included.

\section{Make Wiring Connections}

Wire directly to switch terminals according to particular requirements of the application. See figure 2. For dual switch Types E55A and E55AS, if switches are to be set apart, connect wiring so that switch No.2 will function at the higher temperature.

4. Adjust Switch Settings for dual switch types, switches are factory set to actuate together within $5 \%$ of range (switch No.2 set on dial) but may be set to actuate up to $100 \%$ of scale range apart. Either switch may be set to agree with the dial. See Part II, paragraphs (3 or 4) for instructions.

\section{Start - Up Process}

Turn dial knob to the desired temperature setting. Controller is ready for operation. Minor adjustments might be necessary to obtaining better setpoint accuracy after installing the unit in a particular process. See Part II for instructions. 
1. General - Read before making adjustments.

Calibrating Bath - Place the sensing bulb and the amount of capillary to be exposed to process temperatures into the bath, preferably circulating liquid. Bath temperature should be where the greatest setting accuracy is desired or approximately mid - range.

Test Thermometer - Use an accurate one such as a thermocouple with its probe located next to the sensing bulb.

Stabilization - Before making adjustments allow 5 minutes for the thermal system to adjust to the bath temperature. If controlling a process, make sure the process has stabilized, i.e., successive ON - OFF cycles repeat.

Set Point Reference - Connect test lights to the terminals to indicate switch operation.

\section{Adjusting Single Switch Types E55 and E55S}

Set point adjustment is made by rotating the knob and dial to the desired temperature setting. Controls are factory calibrated, and do not normally require recalibration in the field. However, should this become necessary, follow paragraph .3, steps a through e (below).

\section{Adjusting Dual Switch Types E55A and E55AS No.2 Switch to} Dial $\cdots$

55 Series Controllers are standardly supplied with the No.2 (higher temperature) switch set to the dial. To adjust switch settings for these controllers, proceed as follows. a. First, follow paragraph 1 of this section entitled "General."

b. Set the dial to the same temperature as the test bath.

c. Loosen knob set screw and remove dial, taking care not to rotate the shaft. (Note: Shaft has calibrated flat for easy knob and dial replacement).

d. Using a $1 / 16^{\prime \prime}$ allen head wrench, turn zero adjustment ( $A$ ) until switch No.2 actuates. (Counter clockwise for higher setting.)

e. Replace dial on shaft.

f. Turn dial to a higher setting. equal to temperature differential $\left({ }^{\circ} \mathrm{F}\right)$ desired between switches No. 1 and No. 2.

g. Remove knob and dial for access to the No.1 switch adjustment screm.

h. Using a small screw driver turn in or out the No.1 switch adjustment screw until the No.1 switch actuates.

i. Replace dial, tighten dial set screw to calibrated flat. Controller is ready for operation.

4. Adjusting Dual Switch Types E55A and E55AS, No.1 Switch to Dial

If your controller has been specifically furnished with the No.1 (lower temperature) switch set to the dial, proceed as follows to readjust switch settings:

a. First follow paragraph 3 (above) steps a through $h$.

b. Having completed step h from paragraph 3 , replace knob and dial.

c. Reset dial to the same setting as the bath temperature.

d. Remove knob and dial, and using a $1 / 16^{\prime \prime}$ allen head wrench, turn zero adjustment screw slowly in a counterclockwise direction until the No.1 switch transfers.

e. Replace dial, and adjust to desired setpoint. Controller is ready for operation.

\section{PART III: PARTS REPLACEMENT (See figure 2)}

\section{SWITCH REPLACEMENTS}

To replace switches proceed as follows:

IMPORTANT: Disconnect electrical supply so that switch contacts and terminals are not live.

a. For enclosed types, remove adjustment cover, $\mathrm{knob}$ and dial ; then remove two (2) flat head screws to dismount control body from enclosure. Remove the large rectangular cover plate and rubber gasket from the bottom of the enclosure, and disconnect wiring from the switch terminals.

b. For skeleton and enclosed types, follow instructions $c$. through $\mathrm{g}$.

c. Remove the 2 switch mounting screws; remove the switch or. switches.

d. Insert the new switch (es) and tighten screws.

e. Recalibrate setting (s). See Part II, Adjustments

f. Rewire the new switches and place unit back in its enclosure.

g. Reconnect electrical supply.

\section{THERMAL ASSEMBLY REPLACEMENT}

IMPORTANT: Disconnect Electrical Supply so that switch contact and terminals are not live.

a. For enclosed types, remove adjustment cover, knob and dial; then remove two (2) flat head screws to dismount control body from enclosure. Remove the large rectangular cover plate and rubber gasket from the bottom of the enclosure, and disconnect wiring from the switch terminals.

b. Remove switch mounting screws. Remove switches and insulators.

c. Disengage actuating lever extension spring and remove lever.

d. Remove clamp that secures capillary (located on inside of mounting bracket).

e. Pull the diaphragm down and away from the adjusting screw stem. Do not allow bi - metal washers to slide off diaphragm assembly. (NOTE: Some units will not have bi - metal washers).

f. Using old diaphragm assembly as a pattern, coil the small 
length of copper capillary on the new assembly in the same mentiter.

6. Tranter the bi - metal washers to the new diaphragm remilibly. Be sure that the stamped "O' $\mathrm{s}$ " on the concave surfaces of the washers are on the inside, adjacent to each other.

h. Slide now assembly fully into adjusting shaft. Hold in place while securing with mounting clamp.

i. Install flipper plate so that bumped radius in center of plate is resting on center of diaphragm.

i. Hold flipper plate in place, and using small screw driver or narrow pliers engage loose end of extension spring to the tab on bracket.

k. Align switches with mounting holes in bracker. (NOTE: 'Switch plunger(s) should be furchese away from the end of flipper plate that is anchored by the extension spring.)

I. For enclosed types, slide skeleton unit into enclosure, orienting unit so that adjustment for the second switch is aligned with the opening provided. Socure unit with the (2) flat head screws.

Bend capillary into slot on conduit end of enclosure \& secure with rubber gasket and cover plate.

m. To recalibrate control, refer to.PART II, ADJUSTAAENTS.

\section{FIGURE 1 MOUNTIMG OIMENSIONS}

\section{ENCLOSED TYPES}

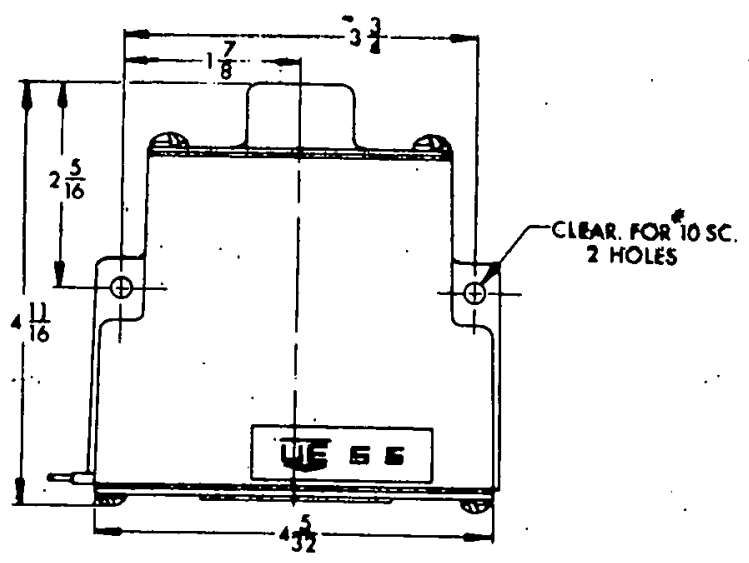

SKELETOH : TYPES

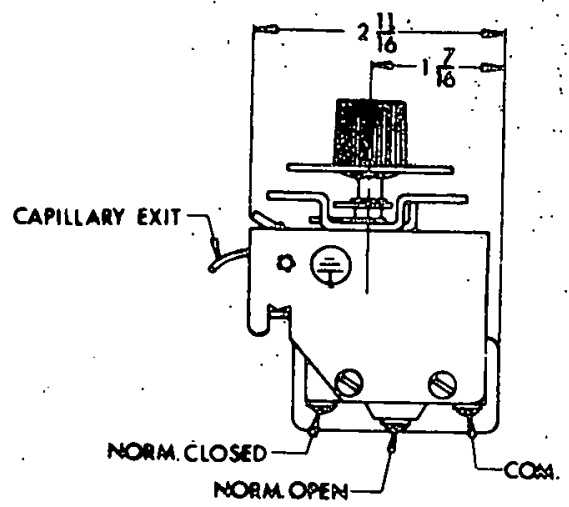

maUTIM EVT.OUT

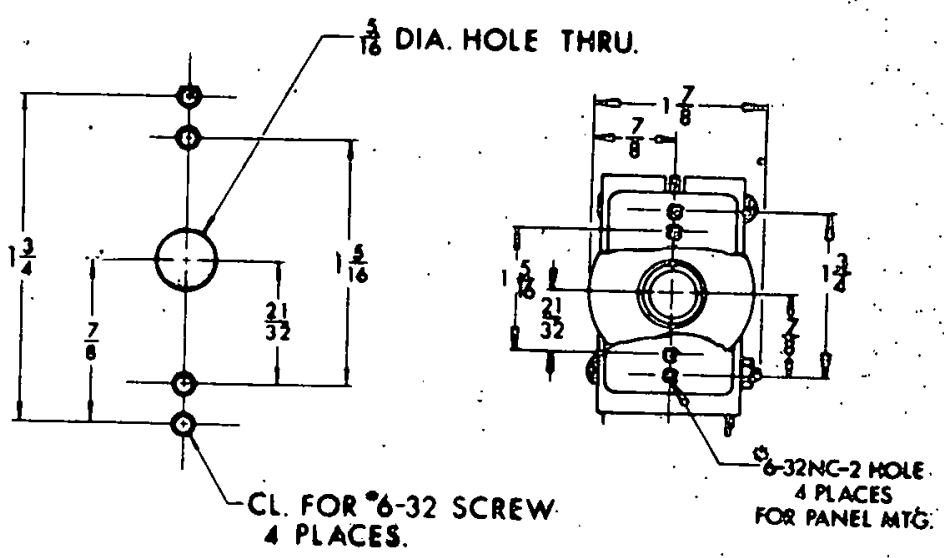

4 PLACES.

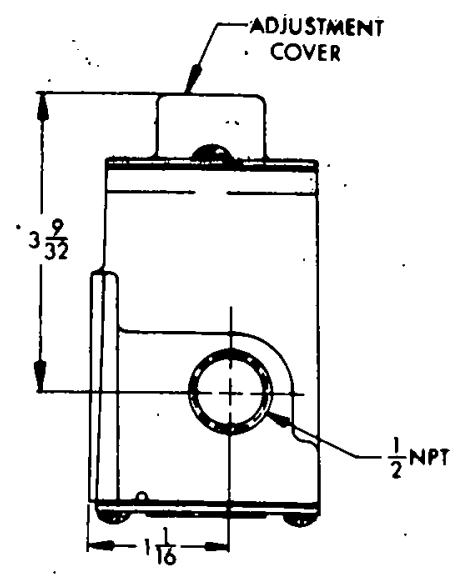
IOP VIEW)
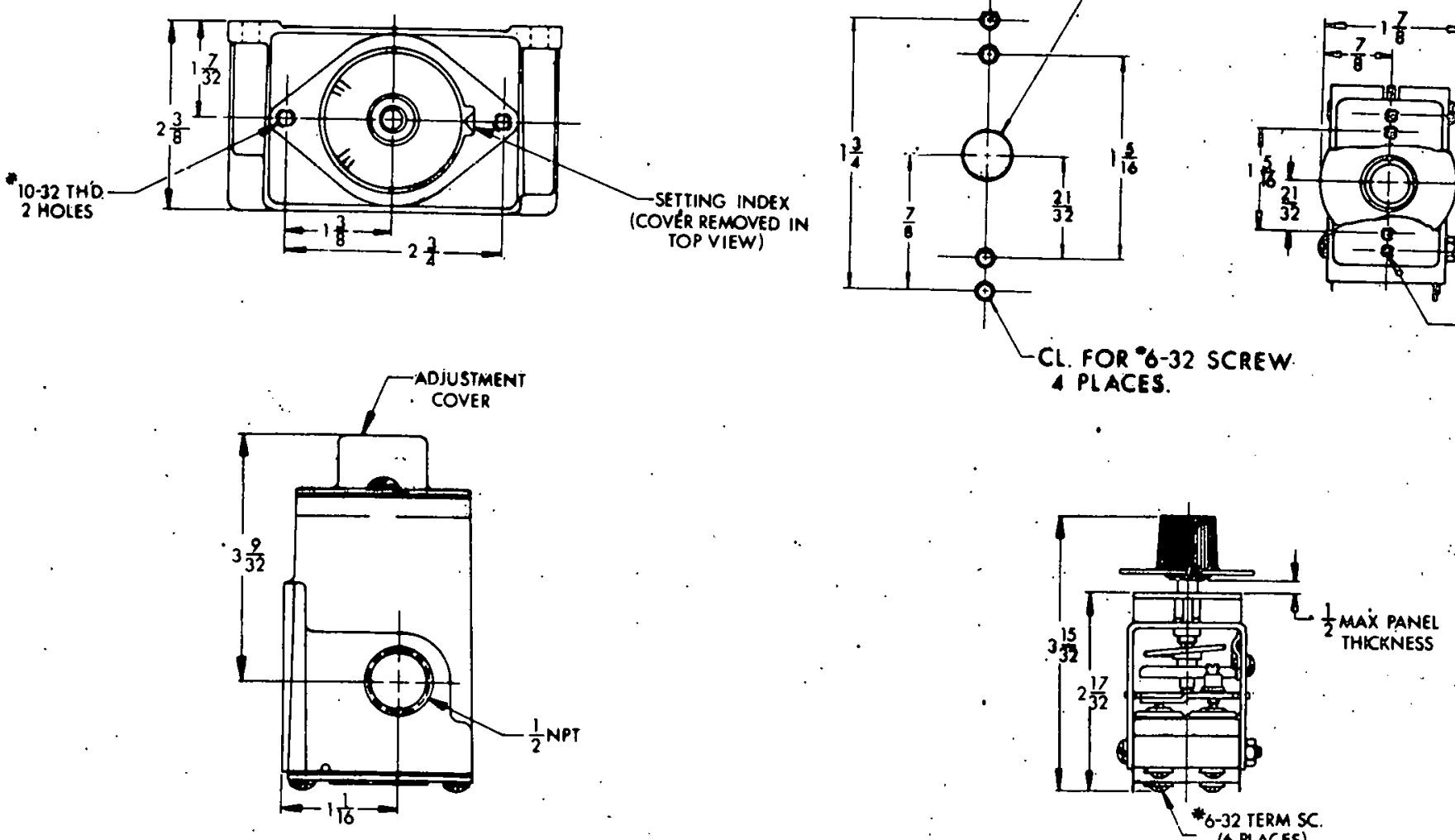


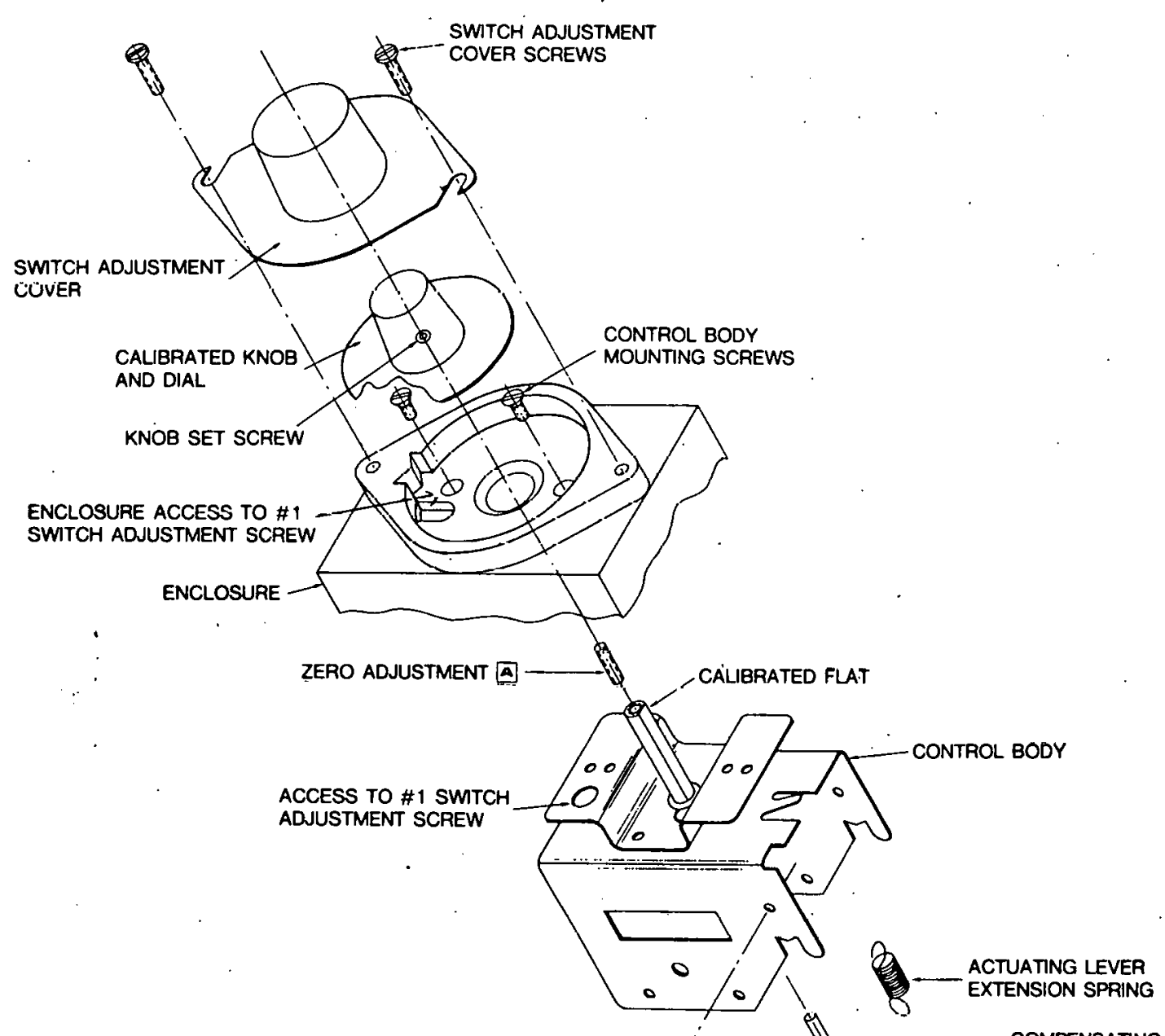
CUUER

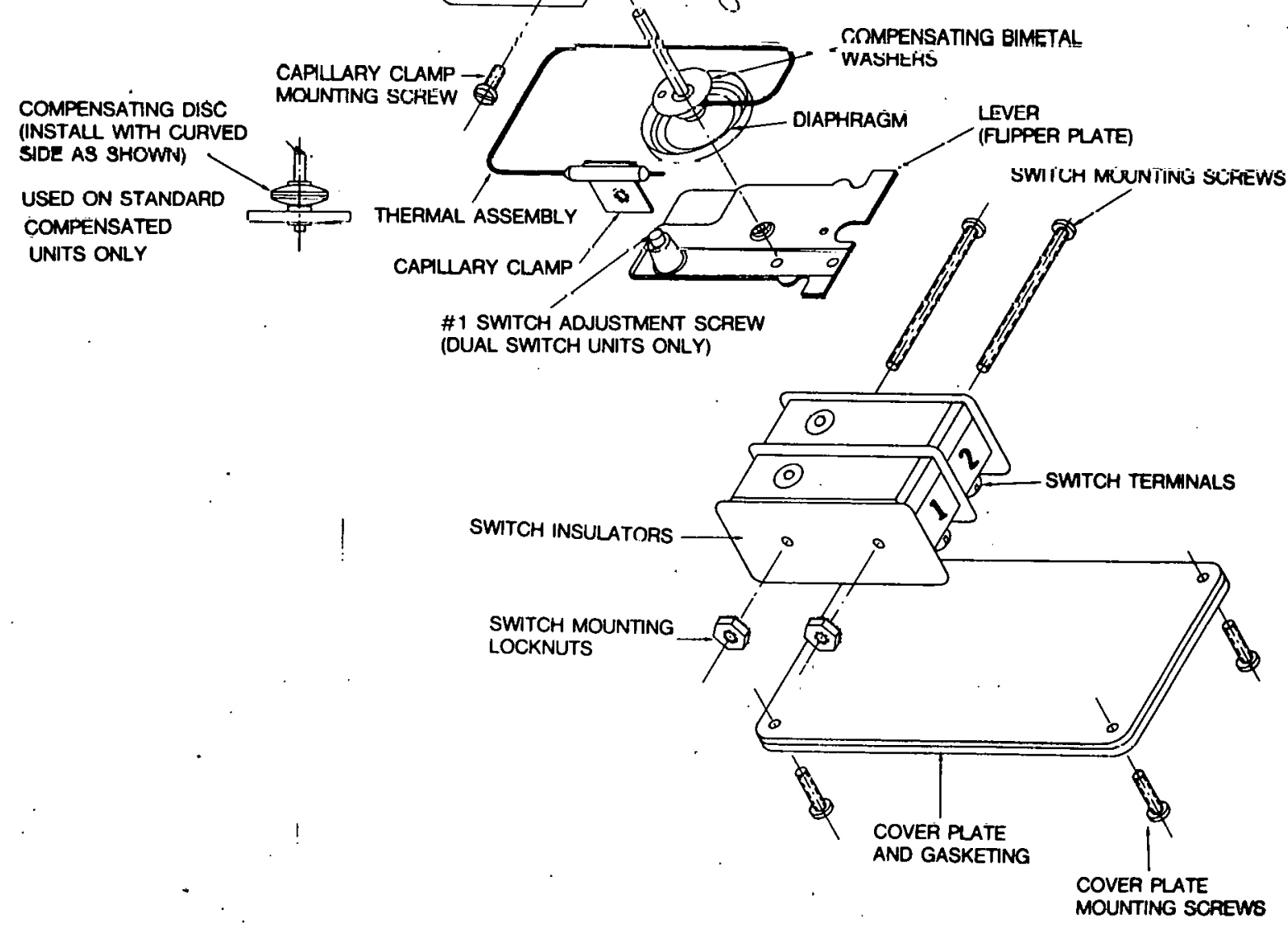

COMPENSATING DISC (INSTALL WTH CURVED SIDE AS SHOWN) COMPENSATED UNITS ONLY
CONTROL BODY

TING SCREWS

THERMAL ASSEMBLY

1 SWITCH ADJUSTMENT SCREW DUAL SWTCH UNITS ONLY) 
APPENDIX C

BELL AND GOSSETT 1535 PUMP

$\mathbf{C}-\mathbf{i}$ 


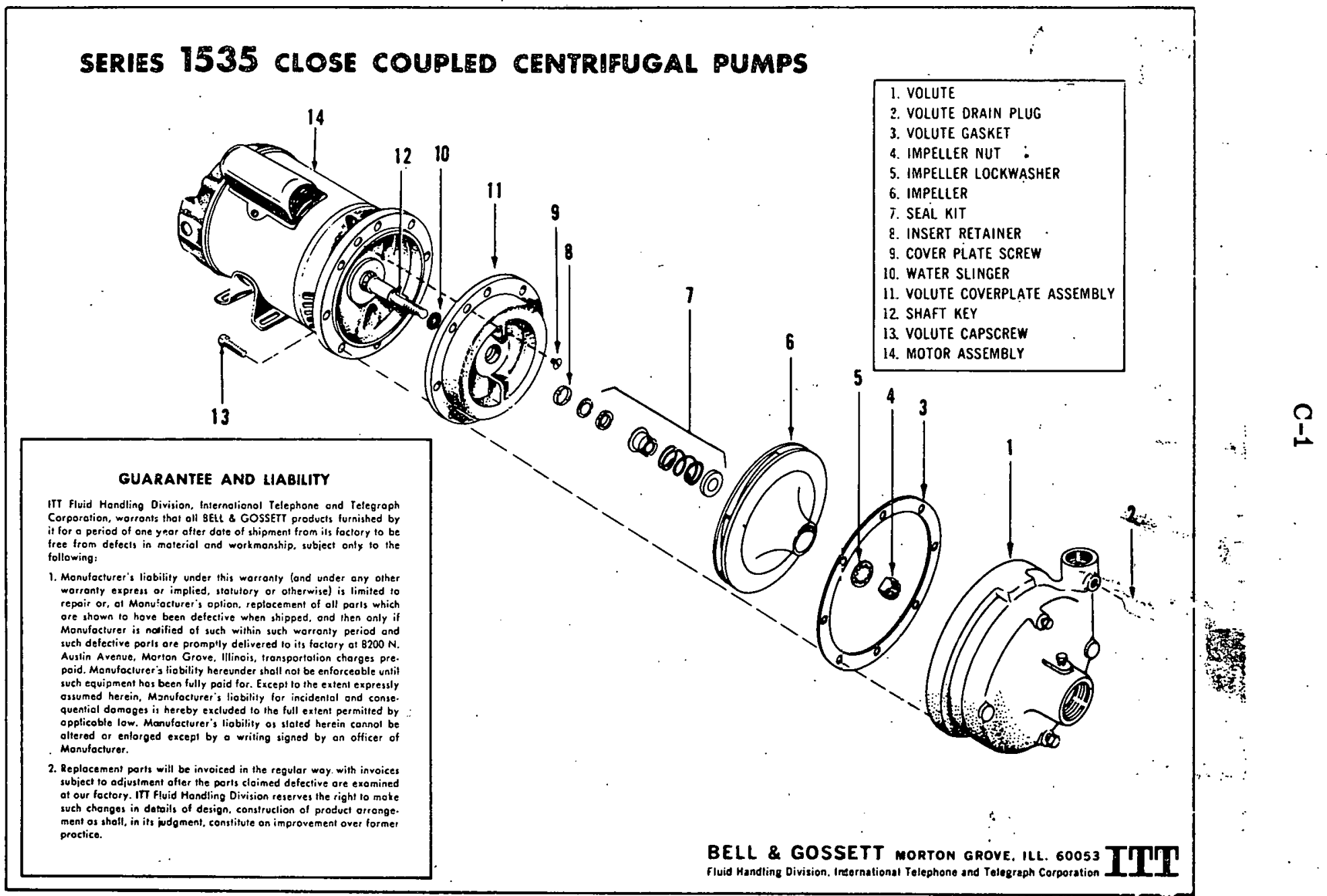


APPENDIX D

THRUSH CENTRIFUGAL PUMPS

D-i 


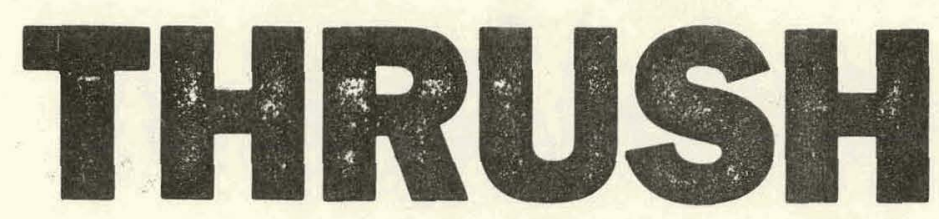

\section{Operating \& Maintenance Instructions for}

\section{$\mathrm{PC}_{2 \mathrm{~g}}$ CLOSE COUPLED END SUCTION CENTRIFUGAL PUMPS}

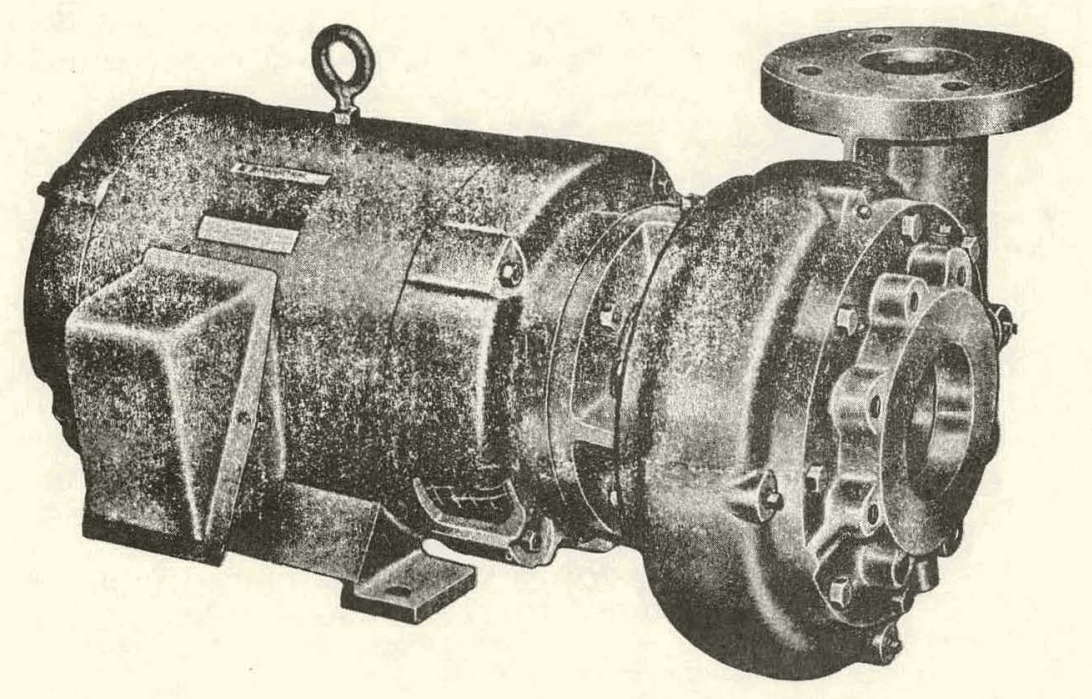

Your Thrush End Suction Centrifugal Pump has been carefully assembled and factory tested to provide years of trouble-free service. In order to insure the service intended, the following information is provided to enable proper installation, operation and maintenance of this product.

Disassembly... . . . . . . . . . . . . . . . . 4

Discharge Piping . . . . . . . . . . . .

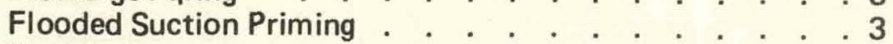

Foundation . . . . . . . . . . . . . . . . . . . . 2

Grouting, if base plate is used . . . . . . . . . . . . . 2

Installation . . . . . . . . . . . . . . . . 2

Location . . . . . . . . . . . . . . . . 2

Maintenance . . . . . . . . . . . . . . . . 4

Mechanical Seals . . . . . . . . . . . . . . . . 7

Mounting . . . . . . . . . . . . . . . . . 2

Jperation . . . . . . . . . . . . . . . 3
Parts List . . . . . . . . . . . . . . . . 5

Piping . . . . . . . . . . . . . . . . . 2

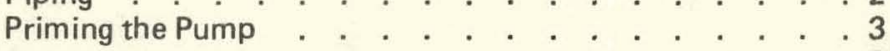

Reassembly. . . . . . . . . . . . . . . . 6

Service . . . . . . . . . . . . . 6

Starting the Pump . . . . . . . . . . . . . . 4

Suction Lift . . . . . . . . . . . . . . $3 \& 4$

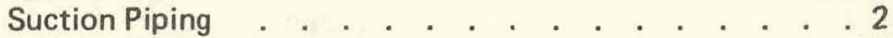

Troubleshooting . . . . . . . . . $7 \& 8$

Vacuum Priming . . . . . . . . . . . . . . . . 4 
INSTALLATION

\section{LOCATION}

The pump should be located as close to the liquid source as possible so that the suction line can be short and direct. It should be located in a clean, open area, where it is easily accessible for inspection, lubrication and repair. Pumps installed in dark, dirty areas or in cramped locations are often neglected which can result in premature failure of both the pump and the driver.

Adequate provisions should be made for electrical wiring to the pump motor. A switch and overload protection should be installed near the pump unless it is impractical. The electrical conduit should be positioned in such a way as to preclude the possibility of moisture entering the conduit or the motor and causing short circuits.

\section{FOUNDATION}

The foundation must be sufficiently rigid to absorb any vibration and stress encountered during pump operation. A raised foundation of concrete is preferable for most floor mounted pumps. The raised foundation assures a satisfactory base, protects against flooding, simplifies moisture drainage and facilitates keeping the area clean.

The pump should be firmly bolted to the foundation, whether it is a raised concrete base, steelwork wall, or structural member. The mounting bolts or studs should be accurately located per the applicable Thrush dimension sheet. Foundation bolts should be enclosed by a sleeve 2 to 4 diameters larger than the bolt to allow movement for proper alignment with the pump mounting holes. Refer to figure 1. If the pump is to be mounted on steelwork or other structure, adequate support should be provided to prevent distortion of the base plate or the structure, which could produce excessive strain on the pump casing and piping and seriously affect alignment of the pump and driver.

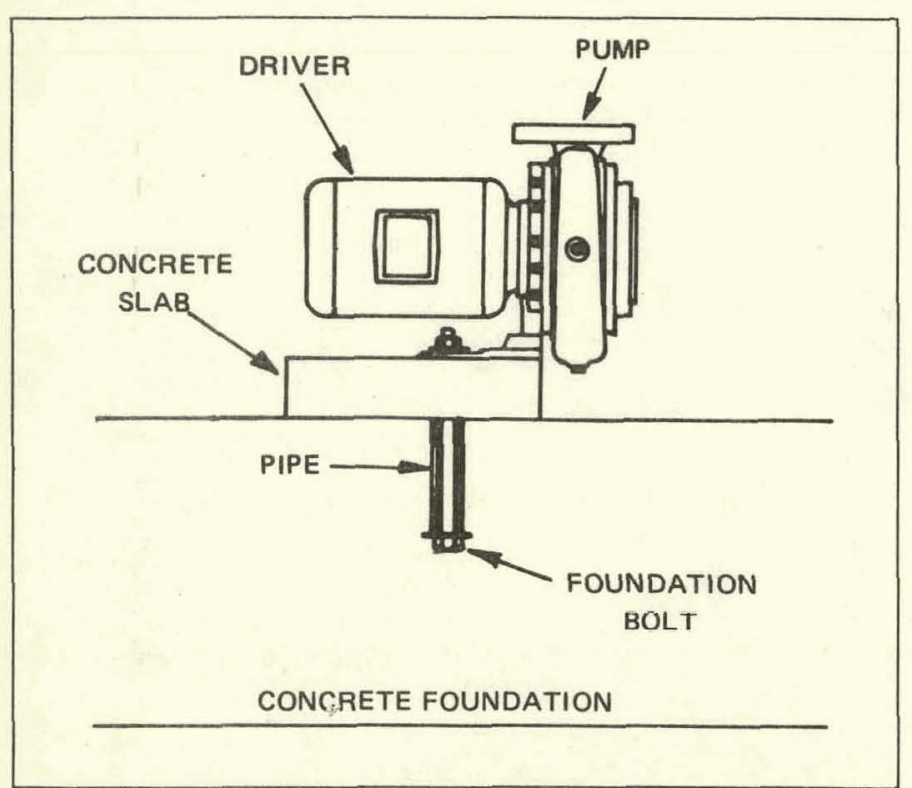

FIGURE 1. FOUNDATION FOR CLOSE-COUPLED PUMPS

\section{MOUNTING}

The pump unit should be set on the foundation, being careful not to damage the threads on the foundation bolts. Shims should be inserted and the pump leveled. A spirit level should be used on the faces of the suction and discharge flanges. If the pump has threaded nozzles, a short piece of pipe inserted in the nozzles will serve as a smooth surface for a leveling reference point. The shims should be adjusted until the pump is leveled horizontally and vertically. Tighten the foundation bolts finger tight.

\section{GROUTING, IF BASE PLATE IS USED}

Grouting the base plate prevents lateral movement of the base plate and improves the vibration absorbing characteristics of the foundation by increasing its mass. A wooden dam should be constructed around the base plate to contain the grout while it is being poured. The entire base plate should be filled with grout, allow 48 to 72 hours for grout to dry. After grout is thoroughly dried, firmly tighten foundation bolts.

\section{PIPING}

The piping practices you follow will directly affect the efficiency and power consumption of your pump. Pay particular attention to the seemingly insignificant details involved in piping for they make the difference between a good and bad installation. BOTH THE SUCTION AND THE DISCHARGE PIPING SHOULD BE INDEPENDENTLY SUPPORTED NEAR THE PUMP. LIBERAL USE OF PIPE HANGERS AND SUPPORT BLOCKS WILL PREVENT EXCESSIVE STRAIN ON THE PUMP CASING AND ON THE PIPE JOINTS. The suction diameter should be at least the same diameter as the suction nozzle on the pump and preferably larger. Use of a smaller diameter pipe will result in loss of head due to friction. All joints must be tight to maintain prime on the pump.

\section{SUCTION PIPING}

Long radius elbows should be used in place of standard elbows wherever possible, because of their superior flow characteristics. Elbows should not be used at suction nozzle, but if it is unavoidable, long radius elbows should be used. Elbows installed in any position at the suction nozzle have a tendency to distribute the liquid unevenly in the impeller eye and may cause a reduction in capacity, create an undesirable thrust condition, or create noisy operation. Eccentric reducers should be installed directly at the suction nozzle, with the taper at the bottom to prevent air pockets from forming. Straight taper reducers should never be used in a horizontal suction line because of the air pocket that is formed at the leg of the reducer and the pipe. Refer to figure 2. 


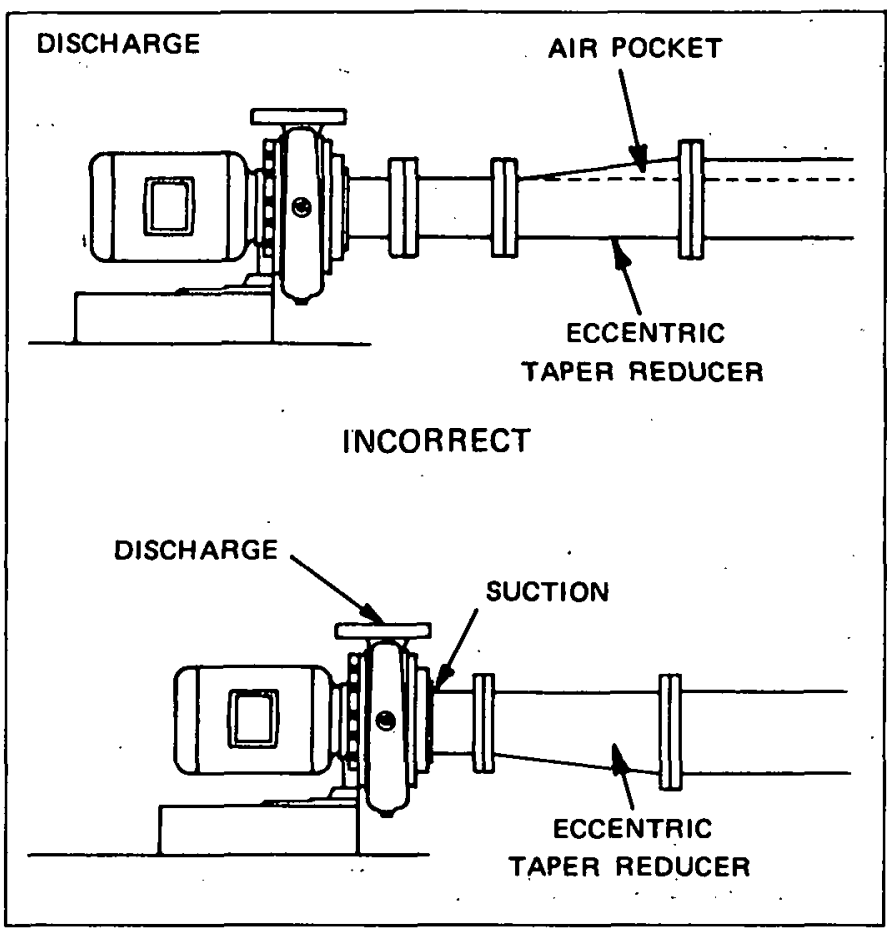

FIGURE 2.

CORRECT

DISCHARGE PIPING

The discharge pipe diameter should be the same as, or larger than, the discharge nozzle diameter. The size of the discharge pipe to be used is dependent upon its application.
Long radius elbows should be used in the discharge piping as well as in the suction piping to prevent excessive head loss due to friction. Whenever possible, elbows should not be installed directly at the discharge nozzle as the turbulence created by the elbow will affect pressure gauge readings.

An increaser should be installed at the discharge nozzle if larger diameter discharge piping is used. Straight taper increasers and/or reducers are satisfactory in discharge applications.

Expansion joints are used primarily to prevent the transmission of piping strain, caused by thermal expansion and contraction, piping misalignment, pressure changes, or other causes, to the pump casing. They are also used to suppress any noise that may be transmitted through the piping. It is recommended that the flexible metal type of expansion joint be used, because rubber expansion joints, while costing less, have a tendency to deteriorate, making frequent replacement necessary.

PROPER PIPING ALIGNMENT IS ESSENTIAL BEFORE CONNECTION IS MADE. PIPING ALIGNMENT SHOULD NEVER BE ACHIEVED BY FORCE, THIS COULD PRODUCE STRAIN ON THE PIPING AND THE PUMP CASING. PROPER SUPPORTS SHOULD BE INSTALLED FOR THE PIPING TO KEEP ITS WEIGHT OFF THE PUMP CASING.

\section{OPERATION}

NOTE: CENTRIFUGAL PUMPS SHOULD NEVER BE STARTED OR RUN DRY. OPERATING A PUMP DRY WILL CAUSE SCORING OF THE MECHANICAL SEAL, RESULT. ING IN PREMATURE SEAL FAILURE. TO PREVENT THE PUMP FROM BEING RUN DRY, IT SHOULD BE PRIMED BEFORE STARTING.

\section{PRIMING THE PUMP}

Your pump will not operate satisfactorily until it is primed. All air must be expelled from the suction piping and pump casing and replaced by the liquid to be pumped. There are several methods of priming pumps. The one you select will depend on your specific requirements.

\section{FLOODED SUCTION PRIMING}

This method of priming a pump is relatively simple. Fig. 3.

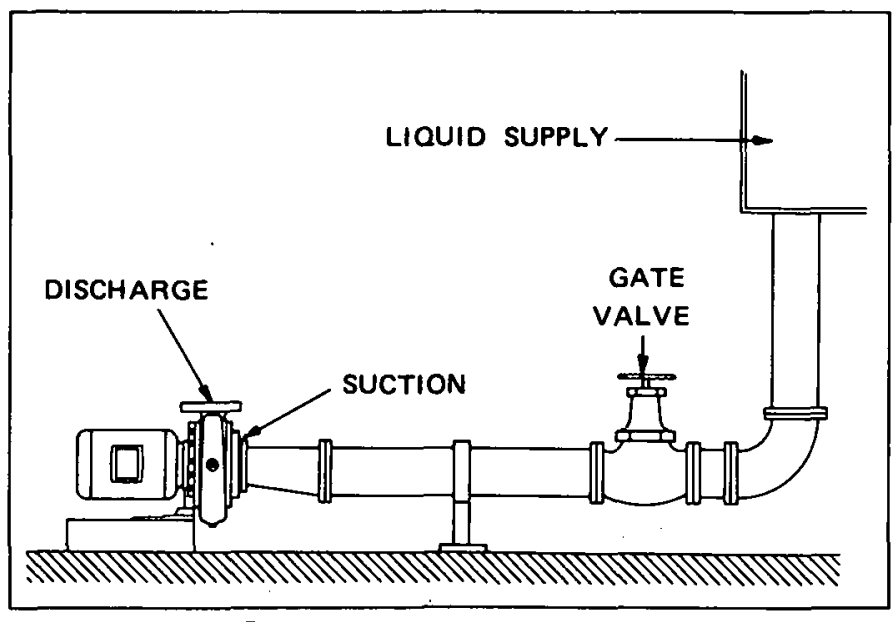

FIGURE 3.
The liquid source is located above the pump and all that is necessary to prime the pump is to open the air vent valve or plug. in the pump casing and to crack the gate valve in the suction line. The suction line and pump should be filled slowly until a steady stream of liquid is observed flowing from the air vent. After the pump is operating it is recommended that the air vent valve or plug be opened again to insure that all air has been expelled from the pump casing.

\section{SUCTION LIFT}

A. foot valve should be used for priming on suction lift applications, Fig. 4. The foot valve located at the bottom end or foot of the suction piping, functions as a check valve which allows flow in one directlon only, toward the pump. Otherwise, all the liquid may drain from the pump and suction piping back into the sump after shutdown.

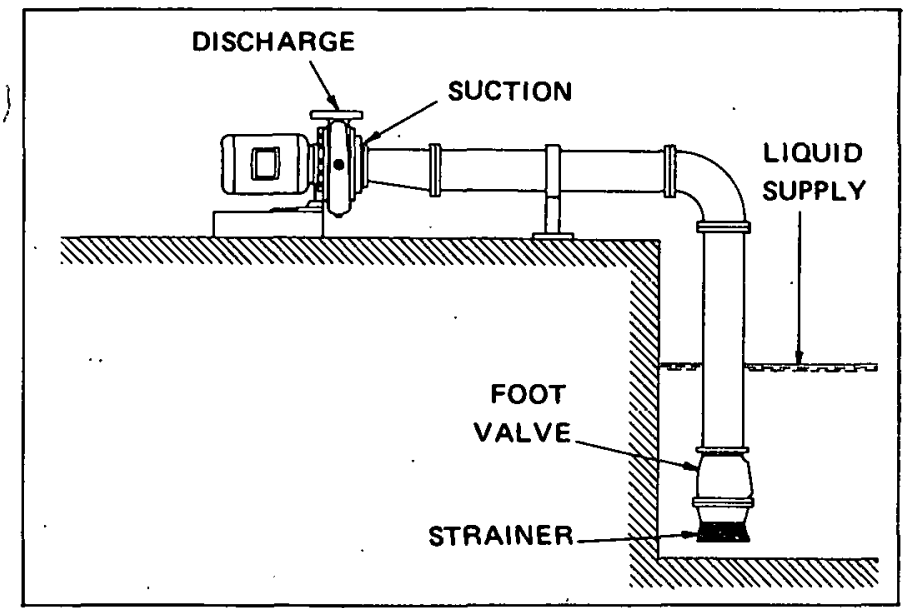

FIGURE 4. 
Initial priming is accomplished by completely filling the suction piping and pump casing with the liquid to be pumped. This can be done by removing the air vent valve or plug at the top of the pump casing, and inserting a pipe nipple in the orifice with an appropriate increaser to accommodate a hose connection. A priming line can also be inserted in the discharge piping between the check valve and the pump, or the priming can be done with a bucket and funnel. The important thing is to completely fill the suction pipe and pump casing with liquid.

When the pump is started, the vacuum created by pumping the priming fluid, combined with atmospheric pressure in the liquid well, forces liquid into the suction piping, thus opening the valve and keeping it open until the pump is shut down. When the pump is shut down, the liquid being pumped reverses its flow causing the valve to close. The liquid is now trapped in the suction piping and pump casing, thus maintain. ing a prime on the pump.

\section{VACUUM PRIMING}

Vacuum priming consists of removing air from the pump casing and suction piping and drawing liquid into them by means of a vacuum creating device. The types of vacuum equipment range from a simple hand pump to a complex central priming systems. Your specific priming requirements will govern what type of vacuum primer you use.

\section{STARTING THE PUMP}

The discharge gate valve should be partially closed when the pump is started in order to avoid possible water hammer and initial power draw. As soon as the pump is up to operating speed, the discharge gate valve should be opened to the desired position.

\section{MAINTENANCE}

It is doubtful that your Thrush pump will ever require complete disassembly, generally only certain components need be disassembled to accomplish inspection or repair.

\section{DISASSEMBLY}

Since your Thrush PC2g pump is of back pull out design, it is unnecessary to disconnect the piping or casing for service. All service and maintenance can be performed by disconnecting the electric service and removing the bracket-motor assembly from the casing.

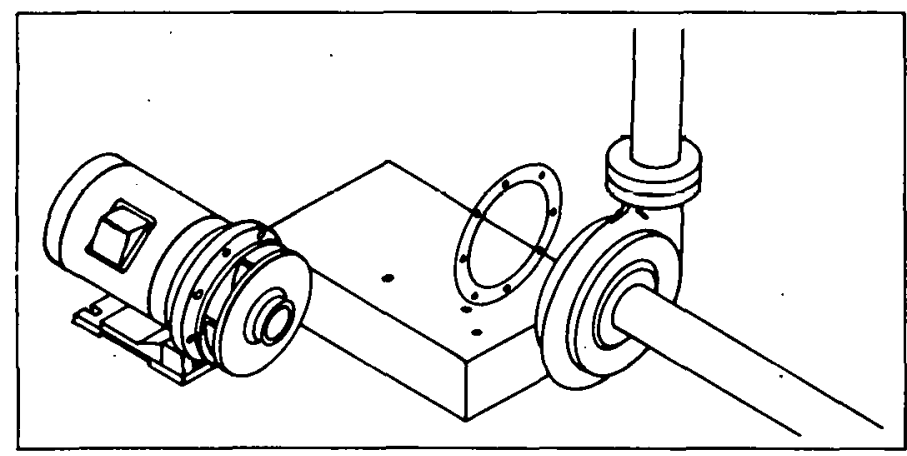

FIGURE 5 .

1. Close suction and discharge valves.

2. Break electrical connections to prevent drive unit from being energized during disassembly.

3. Unscrew two of the pipe plugs (29) from top and bottom of the casing (28).

4. Remove all relief, cooling, flushing or drain lines, if present, from the pump.

5. Disconnect wiring to motor, unscrew hold down bolts that hold down support foot (24) to foundation.
6. Remove capscrews (30) from bracket (15) and pull motor-bracket assembly from casing (28). Remove casing gasket (27).

7. Unscrew impeller screw (35) and remove washer (34), taking care not to damage gaskets ( $33 \& 36$ ).

8. Slide impeller (37) and impeller key (14) from the shaft, again taking care not to damage sleeve gasket (23) located behind impeller. Remove sleeve gasket (23).

9. Suction head wear ring (39) is pressed into suction head (32) with an interferance fit and must be removed with a puller it replacement is necessary.

10. If replacing seal cartridge assembly $(19,20,21 \& 22)$ slide seal assembly off the shidt.

10A. If replacing mechanical seal only $(21 \& 22)$ slide seal assembly off the shaft $(19,20,21 \& 22)$. Remove snap ring (20) at spring end. Remove spring and seal head (22). The rubber in seal head (22) may be partially adhered to shaft sleeve (19). Remove seat and o-ring (21). The sleeve should be carefulty cleaned to remove any residue in seal area, and checked for abrasion or corrosion. The sleeve under the seal may be polished lightly to 32 RMS finish before replacing seal assembly $(21 \& 22)$ (DO NOT REUSE A PITTED SLEEVE)

NOTE: THE MECHANICAL SEAL IS A PRECISION PRODUCT AND MUST BE TREATED AS SUCH. DURING REMOVAL GREAT CARE MUST BE TAKEN TO AVOID DROPPING ANY PART OF THE SEAL. TAKE PARTICULAR CARE NOT, TO SCRATCH THE LAPPED FACES ON THE WASHER OR THE SEALING SEAT. DO NOT PUT A SEAL BACK INTO SERVICE UNTIL THE SEALING FACES OF THE WASHER AND SEAT HAVE BEEN LAPPED OR REPLACED. 


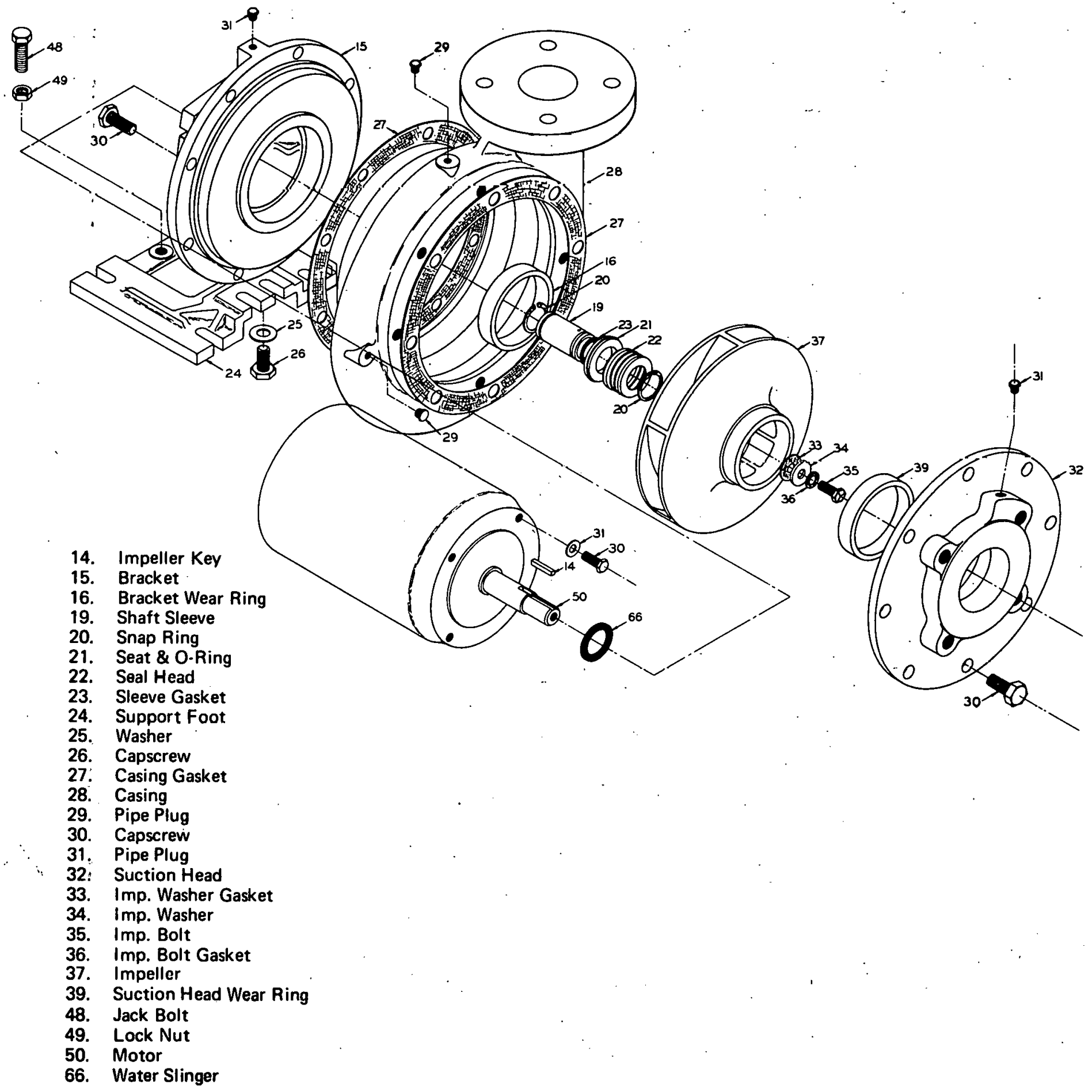

BOLD FACE NUMBERS INDICATE RECOMMENDED SPARE PARTS.

FIGURE 6. PUMP AND POWER FRAME, EXPLODED VIEW 
9: The seal cavity of the bracket (15) should be cleaned of all residue. Make sure that the $1 / 32$ inch radius in the seal seat cavity is not damaged during disassembly since a sharp edge can easily cut the " $O$ " Ring during reassembly.

12. Remove capscrews (26) and washers (25) to take off support foot (24).

13. Unscrew capscrews (30) and pipe plug (31) to remove bracket (15) from motor.

14. Remove impeller key (14) from the shaft and remove water slinger (66).

\section{REASSEMBLY}

1. Mount bracket (15) by screwing capscrews (30) and pipe plug (31) evenly into motor to assure proper alignment. Turn all capscrews in an even amount. Attach the bracket support foot (24) by placing washers (25) over capscrews (26) and screwing them into position.

2. Thoroughly inspect the seal cavity in the bracket for burrs or nicks which could damage the seat of the seal. APPLY A FILM OF SOAP PASTE OR FLAX SOAP (DO NOT USE OIL OR GREASE) TO THE SEAT AND O-RING (21).

If replacing seal cartridge assembly, remove card board spacer and slide assembly $(19,20,21 \& 22)$ onto motor shaft (50).

If it is not possible to insert seal assembly with fingers, press into place a piece of tubing having end cut square and matching sleeve diameter. Tubing should be slightly larger than the diameter of the shaft. Spring tension will probably prevent the sleeve from remaining in position axially until the impeller is locked against it.

2A. When replacing mechanical seal only $(21 \& 22)$ wipe the sealing faces of the seat and seal washer clean. Lubricate these surfaces and shaft sleeve (19) with a clean soap solution. Put seat and o-ring (21) on shaft sleeve (19), smooth side to pump end. Slide the entire rotating assembly onto the sleeve. Carbon in seal head must mate with seal seat.
Replace snap ring (20). The shaft sleeve with the seal rotating assembly on it may now be replaced onto the pump shaft. Spring tension will probably prevent the sleeve from remaining in position axially until the impeller is locked against it.

3. Press suction head wear ring (39) in suction head if change is necessary. Rings should not be hammered into place. Use a press, or clamp the parts in a bench vise, using wooden blocks to protect the rings. It may be necessary to pin or dowel the rings after assembly if the insert or casing has had rings replaced before, since each reassembly can stretch or tear metal and thereby loosen the fits. If the facilities are available, it is good practice to take a very light finish cut or to ream the inside diameter of the casing rings after pressing to restore roundness. When rings are pressed, they may get squeezed out of shape.

4. Replace bracket wear ring (16) in bracket (15).

5. Carefully place sleeve gasket (23) on motor end of impeller. Assemble impeller key (14) and impeller (37) to shaft. Secure impeller with impeller washer gasket (33), impeller washer (34), impeller bolt gasket (36) and impeller bolt (35).

6. Replace casing gasket (27) on bracket (15). Slide entire motor-bracket assembly into casing (28) being careful not to damage casing gasket (27). With assembly properly positioned in casing $(28)$ replace capscrews $(30)$. Turn all capscrews in and tighten evenly.

Replace all hold down bolts securing motor assembly to foundation.

7. Install the two pipe plugs (29) in the pump casing. Position the casing yasket (27) and casing (28) against the pump bracket and secure with capscrews (30).

8. Replare all relief, cooling. flushịng or drain lines.

9. Read carefully the section of the manual titled INSTALLATION.

10. Connect electricity to the motor.

11. Ojeen suction and dischargo valves.

\section{SERVICE}

Your Thrush pump requires no maintenance other than periodic inspection, occasional cleaning and lubrication of bearings. The intent of inspection is to prevent breakdown, thus obtaining optimum service. life. The liquid end of the pump is lubricated by the fluid being pumped and therefore does not require periodic lubrication. The motor, however, may require lubrication, in which case, the motor manufacturer's recommendation should be followed. 
MECHANICAL SEALS

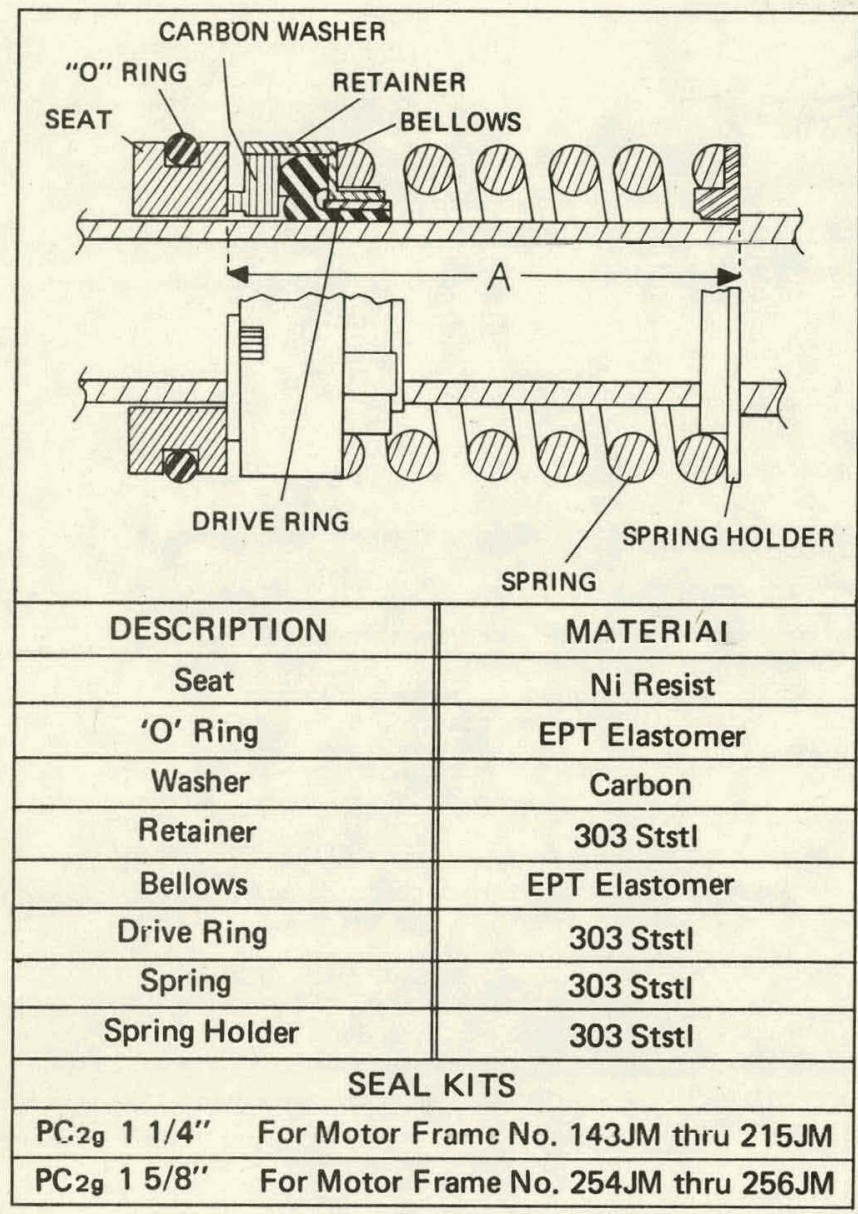

\section{TROUBLESHOOTING HOT WATER SEAL PROBLEMS}

\begin{tabular}{|c|c|c|}
\hline TROUBLE & POSSIBLE CAUSE & REMEDY \\
\hline $\begin{array}{l}\text { Cracked or broken } \\
\text { stationary seat } \\
\text { (Ceramic) } \\
\text { Seat scored or grooved } \\
\text { (Ni.Resist) }\end{array}$ & $\begin{array}{l}\text { Seal ran dry and heated up. } \\
\text { When liquid reached seal } \\
\text { faces it was cooler, causing } \\
\text { thermal cracks } \\
\text { Lack of Lubrication }\end{array}$ & $\begin{array}{l}\text { Check to insure seal } \\
\text { chamber is full of } \\
\text { liquid before starting } \\
\text { pump. On high tempera- } \\
\text { ture application insure } \\
\text { proper flushing at seal } \\
\text { faces }\end{array}$ \\
\hline $\begin{array}{l}\text { Carbon washer scored } \\
\text { and grooved }\end{array}$ & $\begin{array}{l}\text { Dirty system } \\
\text { Treatment level \& temperature } \\
\text { higher than anticipated }\end{array}$ & $\begin{array}{l}\text { Have system cleaned } \\
\text { and flushed. } \\
\text { Upgrade seal seat matl. } \\
\text { Install solids separator } \\
\text { or filter in flush line } \\
\text { Check against chart } \\
\text { and prescribe proper } \\
\text { seal materials or lower } \\
\text { treatment levels }\end{array}$ \\
\hline $\begin{array}{l}\text { Cärbon washer worn } \\
\text { unevenly }\end{array}$ & Seal improperly installed & $\begin{array}{l}\text { Check installation inst. } \\
\text { for proper assembly }\end{array}$ \\
\hline Flexible bellows hard $\&$ brittle & Temperature too high & $\begin{array}{l}\text { Check against chart for proper } \\
\text { materials }\end{array}$ \\
\hline $\begin{array}{l}\text { EPT bellows soft \& } \\
\text { sticky; appears to be } \\
\text { dissolving }\end{array}$ & $\begin{array}{l}\text { Seal assembled with petroleum } \\
\text { base product as lubricant } \\
\text { System contains soluble oil }\end{array}$ & $\begin{array}{l}\text { Install new seal using } \\
\text { soap solution as lubricant } \\
\text { Clean and flush system, } \\
\text { or consult factory for } \\
\text { recommendation }\end{array}$ \\
\hline $\begin{array}{l}\text { Retainer drive tabs } \\
\text { badly worn or broken }\end{array}$ & $\begin{array}{l}\text { Vibration or coupling mis. } \\
\text { alignment } \\
\text { Periodic loss of lubrication at } \\
\text { seal faces }\end{array}$ & $\begin{array}{l}\text { Realign pump \& motor } \\
\text { Insure proper flushing } \\
\text { at seal faces. }\end{array}$ \\
\hline $\begin{array}{l}\text { Flexihle hellows } \\
\text { ruptured }\end{array}$ & $\begin{array}{l}\text { Pressure too high } \\
\text { Coupling misalignment } \\
\text { Temperature too high }\end{array}$ & $\begin{array}{l}\text { See spec sheets for max. } \\
\text { pressure rating. } \\
\text { Realign pump \& motor } \\
\text { Check chart and prescribe } \\
\text { proper seal }\end{array}$ \\
\hline
\end{tabular}




\section{TROUBLESHOOTING}

TROUBLE

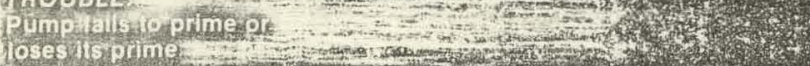

PROBABLE CAUSE

a. Air leaks in suction lines

Suction strainer is clogged

c. Suction lift is too high

d. Defective priming valve

e. Defective packing or sea

\section{REMEDY} connections; relocate suction inlet in liquid source.

b. Remove dirt, leaves or other materials from strainer.

c. Re-evaluate pump requirements and correct suction conditions accordingly.

d. Replace valve

e. Replace packing or seal. a. Clean and tighten all suction

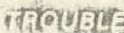

4)

PROBABLE CAUSE

a. Pump is not properly primed

b. Total head is too high

c. Driver is not operating at rated speed

d. Impelier or discharge line is clogged

e. Wrong direction of rotation

f. Pump is vapor bound
REMEDY

a. Reprime the pump; refer to priming troubles and remedies.

b. Re-evaluale head calculations; measure elevation differences between pump and liquid source, and pump and discharge point.

c. Check voltage of electric motor: check steam pressure of steam turbine; check engine R.P.M.'s. Refer to applicable maintenance manuals for possible troubles and corrective action.

d. Back flush pump to clear obstruction; disassemble pump and/or piping and remove obstruction.

e. Check wiring against diagram on motor name plate and in controller: reverse any two power leads on a three-phase motor; replace a single phase motor.

f. Provide additional pressure on liquid being pumped by elevating liquid source or pressurizing the supply tank.

TROUBLE

3. Pump does hot dellver rated capacily

\section{PROBABLE CAUSE}

a. Pump is not properly primed

b. Suction lift is too high

c. Excessive air in liquid

d. Air leakage through stuffing box

e. Driver is not operating at rated speed

f. Impeller is clogged

g. Wearing rings are worn

h. Impeller is damaged

. Pump is vapor bound

TROUBLE:

4. Insurficient pressure

\section{PROBABLE CAUSE}

Excessive air in liquid

b. Drive is not operating at rated speed

c. Wrong direction or rotation

d. Total head is too high

e. Wearing rings are worn

f. Impeller is damaged

g. Casing gasket is defective allowing internal leakage

h. Liquid is vaporizing

\section{REMEDY}

a. See 3.c. above

b. See 2.c. above

c. See 2.e. above.

d. See 2.b. above

f. See 3.h. above.

g. Replace casing gasket.

h. See 2.f. abovc e. See 3.g. above.

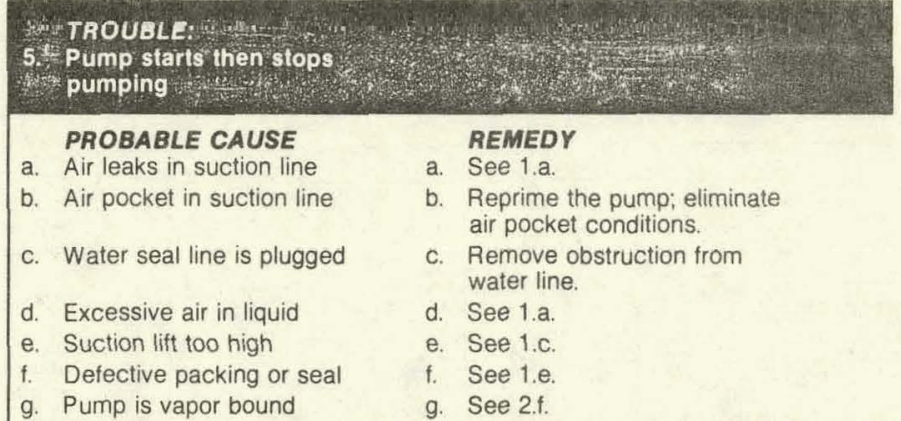

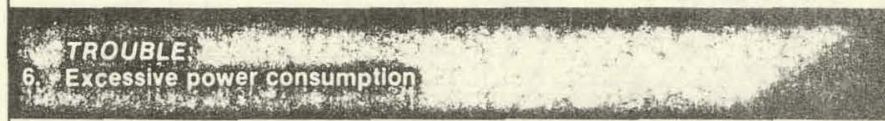

\section{PROBABLE GAUSE \\ a. Speed is too high}

b. Wrong direction of rotation

c. Total head is too high

d. Total head is to low

e. Impeller is clogged

f. Impeller is binding

g. Motor shaft is bent or worn

$h$. Driver and pump are misaligned $h$. Power frame shaft is bent

Wearing rings are worn

k. Packing is incorrectly installed k. Install packings correctly;

\section{TROUBLE: \\ 7. Pump is noisy or has excessive vibration}

\section{PROBABLE CAUSE}

\section{a. Magnetic hum}

b. Motor bearings are worn

I oreign material in impoller

d. Impeller is binding

c. Motor shaft is bent or worn

f. Driver and pump are misaligned

g. Power frame shaft is bent

h. Foundation is not rigid

i. Worn bearing in power frame

Impeller is damaged

k. Lack of lubrication in power frame

I. Pump is not properly leveled

$\mathrm{m}$. Piping is not supported

n. Pump is cavitating replace if necessary.

\section{REMEDY}

a. Internal electric motor wiring is incorrect; replace motor; refer to applicable driver maintenance manuals for nossible troubles and corrective action

b. See 2.e

c. See 2.b.

d. Re-evaluate head conditions; correct as required.

e. See 2.d.

f. Relieve strain on casing; adjust impeller clearance.

g. Replace motor shaft.

h. Realign driver with pump.

i. Replace shait.

j. See 3.g. 


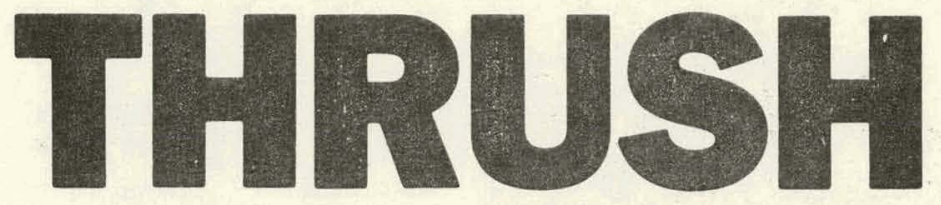

\section{Installation Instructions for}

\section{PF $_{2 g} \&$ PC $_{2 g}$ CENTRIFUGAL PUMPS CARTRIDGE MECHANICAL SEALS}
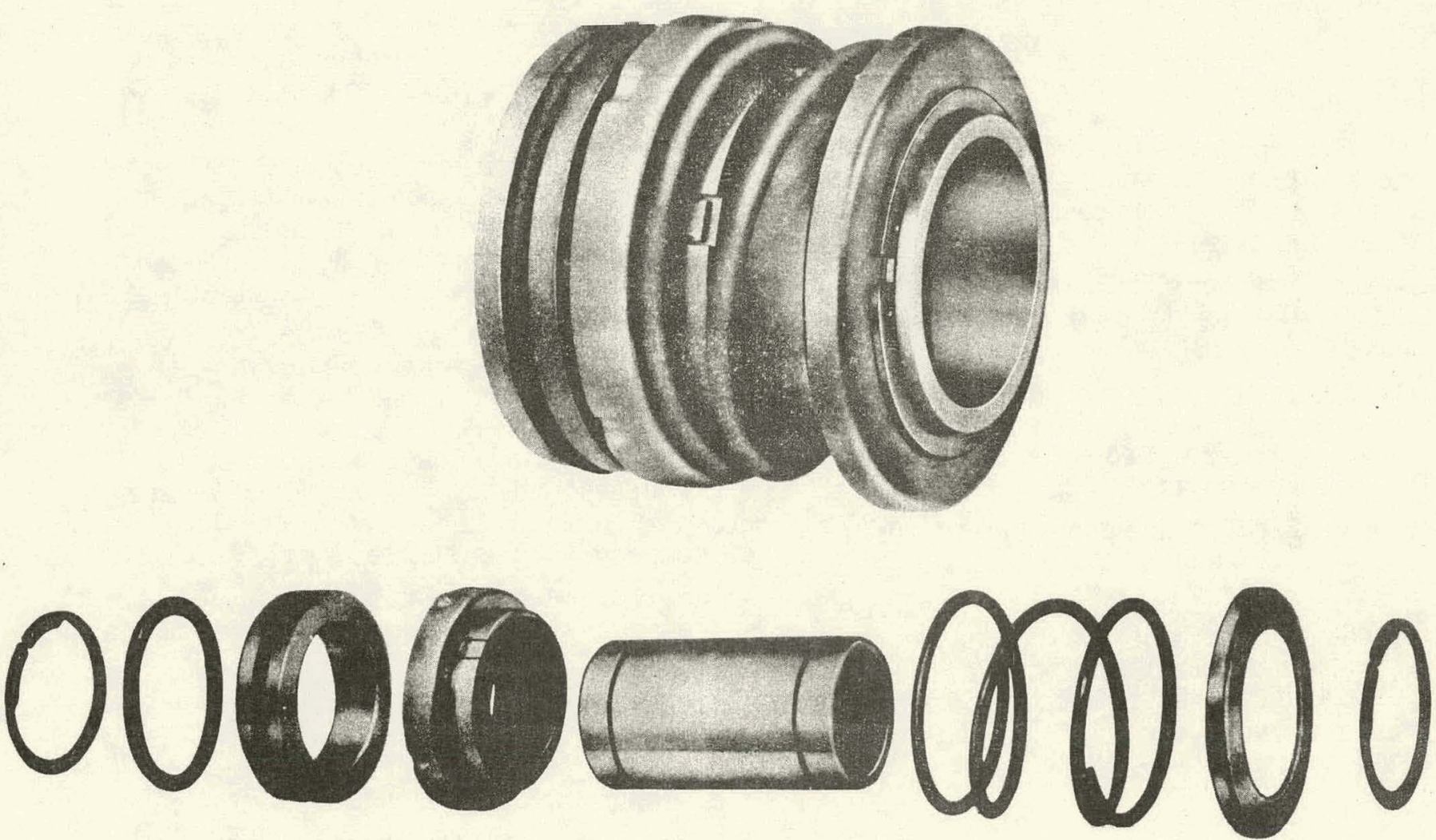

Thrush $\mathrm{PF}_{2 \mathrm{~g}}$ and $\mathrm{PC}_{2 \mathrm{~g}}$ Pumps are of the back pullout design. Therefore, it is unnecessary to disconnect the piping or casing for service. All service and maintenance on $\mathrm{PF}_{2 g}$ pumps can be performed by disconnecting the coupling and removing the power frame assembly from the casing (Fig. 1). On $\mathrm{PC}_{2 g}$ pumps service can be performed by disconnecting motor wiring and removing motor assembly from casing (Fig. 2).
Contents

Disassembly ..................... 2

$\mathrm{PC}_{2 g}$ Parts List. .................. 3

$\mathrm{PF}_{2 g}$ Parts List.................. 3

Reassembly.................... 2

Troubleshooting ................. 4 


\section{DISASSEMBLY}

1. Close suction and discharge valves.

2. Break electrical connections to prevent drive unit from being energized during disassembly.

3. Unscrew two of the pipe plugs (29) from top and bottom of the casing (28).

4. Remove all relief, cooling, flushing or drain lines, if present, from the pump.

5. $\quad\left(\mathrm{PF}_{2 \mathrm{~g}}\right)$ Disconnect the flexible coupling from between the pump and motor. Unscrew the hold down bolts that hold support foot (24) and bearing frame (10) to base.

$5 A$. $\left(P_{29}\right)$ Disconnect wiring to motor. Unscrew hold down bolts that hold support foot (24) to foundation.

6. Remove capscrews (30) from bracket (15) and pull (frame assembly $-\mathrm{PF}_{2 g}$ ) or (motor assembly $-\mathrm{PC}_{2 \mathrm{~g}}$ ) from casing (28). Remove casing gasket (27).

7. Unscrew impeller bolt (35) and remove imp. washer (34), taking care not to damage gaskets ( 33 \& 36 ).

8. Slide impeller (37) and impeller key (14) from the shaft, again taking care not to damage sleeve gasket (23) located behind impeller. Remove sleeve gasket (23).

9. Remove seal cartridge assembly $(19,20,21$ \& 22) from shaft (12).

10. The seal cavity of the bracket (15) should be cleaned of all residue. Make sure that the $1 / 32$ inch radius in the seal seat cavity is not damaged during disassembly since a sharp edge can easily cut the "O" Ring during reassembly.

\section{REASSEMBLY}

1. Thoroughly inspect the seal cavity in the bracket for burrs or nicks which could damage the seat of the seal. Apply a film of soap paste or flax soap (do not use oil or grease) to "O" Ring of the seal seat (21).

2. Remove card board spacer and slide cartridge assembly $(19,20,21 \& 22)$ onto shaft (12). Making sure "O" Ring on seat (21) is properly seated in bracket (15). If it is not possible to insert seal assembly with fingers, press into place a piece of tubing having end cut square and matching sleeve diameter. Tubing should be slightly larger than the diameter of the shaft. Spring tension will probably prevent the sleeve from remaining in position axially until the impeller is locked against it.

3. Carefully place sleeve gasket (23) on motor end of impeller. Assemble impeller key (14) and impeller (37) to shaft. Secure impeller with impeller washer gasket (33), impeller washer (34), impeller bolt gasket (36), and impeller bolt (35).

4. Replace casing gasket (27) on bracket (15). Slide entire (frame assembly - $P F_{2 g}$ ) (motor assembly - $\mathrm{PC}_{2 g}$ ) into casing (28) being careful not to damage casing gasket (27). With assembly properly positioned in casing (28) replace cupsciews (30). Turn all capscrews in and tighten evenly.

Replace all hold down bolts securing pump asscmbly to base or motor assembly to foundation.

5. Install the two pipe plugs (29) in the pump casing. Position the casing gasket (27) and casing (28) against the pump bracket and secure with capscrews (30).

6. Replace all relief, cooling, flushing or drain lines.

7. Read carefully the section of the manual titled INSTALLATION, especially those paragraphs referring to pump and coupling alignment.

8. Connect electricity to the motor.

9. Open suction and discharge valves.

NOTE: The mechanical seal is a precision product and must be treated as such. During installation great care must be taken to avoid dropping any part of the seal. Take particular care not to scratch the lapped faces on the washer or the sealing seat. Do not put a seal back into service until the sealing faces of the washer and seat have been lapped or replaced. 
TECHNICAL REPORT ST ANDARD TITLE PAGE'

\begin{tabular}{|c|c|c|}
\hline $\begin{array}{l}\text { 1. REPORT NO. } \\
\text { DOE/NASA CR-150870 }\end{array}$ & 2. GOVERNMENT ACCESSION NO. & 3. RECIPIENT'S CATALOG NO. \\
\hline \multirow{2}{*}{\multicolumn{2}{|c|}{$\begin{array}{l}\text { TITLE AND SUBTITLE } \\
\text { Solar Heating and Hot Water System Installed at Listerhill, } \\
\text { Alabama }\end{array}$}} & $\begin{array}{l}\text { 5. REPORT DATE } \\
\sqrt{\text { December } 1978}\end{array}$ \\
\hline & & 6. PERFORMING ORGANIZATION COIDE \\
\hline \multicolumn{2}{|l|}{ 7. AUTHOR(S) } & 8. PERFORMING ORGANIZATION REPORT \# \\
\hline \multirow{3}{*}{\multicolumn{2}{|c|}{$\begin{array}{l}\text { 9. PERFORMING ORGANIZATION NAME AND ADDRESS } \\
\text { Reynolds Metals Company } \\
\text { Product. Development Division } \\
\text { Richmond, Virginia } 23261\end{array}$}} & 10. WORK UNIT. NO. \\
\hline & & $\begin{array}{l}\text { 11. CONTRACT OR GRANT NO. } \\
\text { DOE-G-77-A-01-4070 }\end{array}$ \\
\hline & & 13. TYPE OF REPOR I \& PERIOD COVERED \\
\hline \multirow{2}{*}{\multicolumn{2}{|c|}{$\begin{array}{l}\text { 12. SPONSORING AGENCY NAME ANO ADORESS } \\
\text { National Aeronautics and Space Administration } \\
\text { Washington, D. C. } 20546\end{array}$}} & Contractor Report \\
\hline & & 14. SPONSORING AGENCY CODE \\
\hline
\end{tabular}

This work was done under the technical management of Mr. Dan Henry, George C. Marshall Space Flight Center, Alabama.

16. ABSTRACT

A cooperative agreement was negotiated in September 1977 for the installation of a space and domestic hot water system at the Reynolds Metals. Shower and Change Facility in Listerhill, Alabama, in cooperation with the U.S. Energy Research and Development Administration (now part of the Department of Energy). The Project Manager for this cffort was Mr. W. W. Foster.

The solar system was installed into a new building and was designed to provide $79 \%$ of the estimated annual space heating load and $59 \%$ of the estimated annual potable hot water requirement. The collectors are flat plate, liquid manufactured by Reynolds Metals. Company and cover a total area of 2344 square feet. The storage medium is water inhibited with NALCO 2755 and the container is an underground, unpressurized steel tank with a capacity of 5000 gallons.

This final report describes in considerable detail the solar heating facility and contains detailed drawings of the completed system. The facility was declared operational in April 1978, dedicated on "Sun Day, "May 3, 1978; and has functioned successfully since.

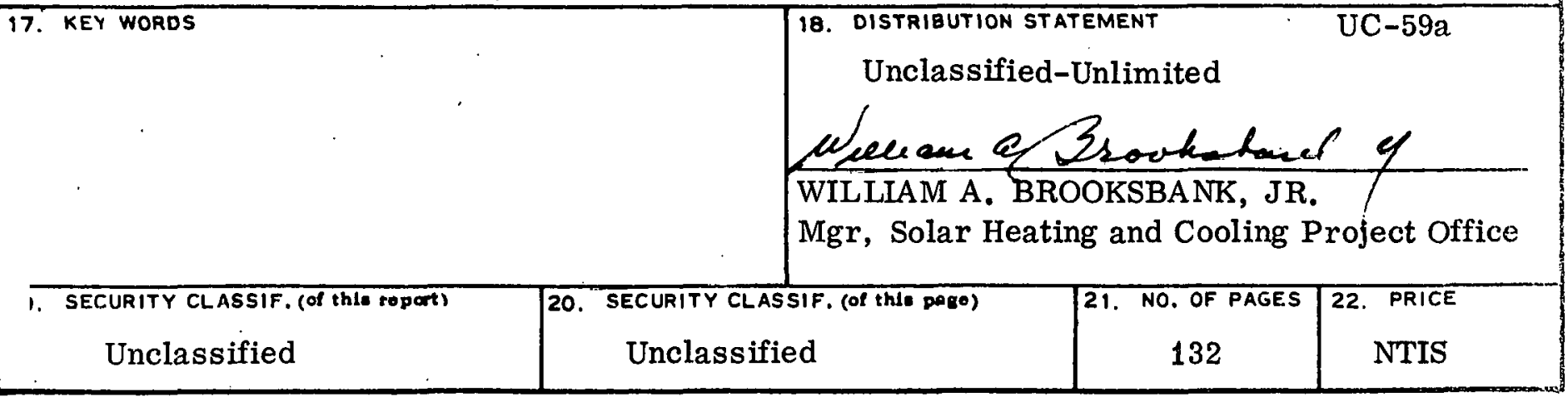



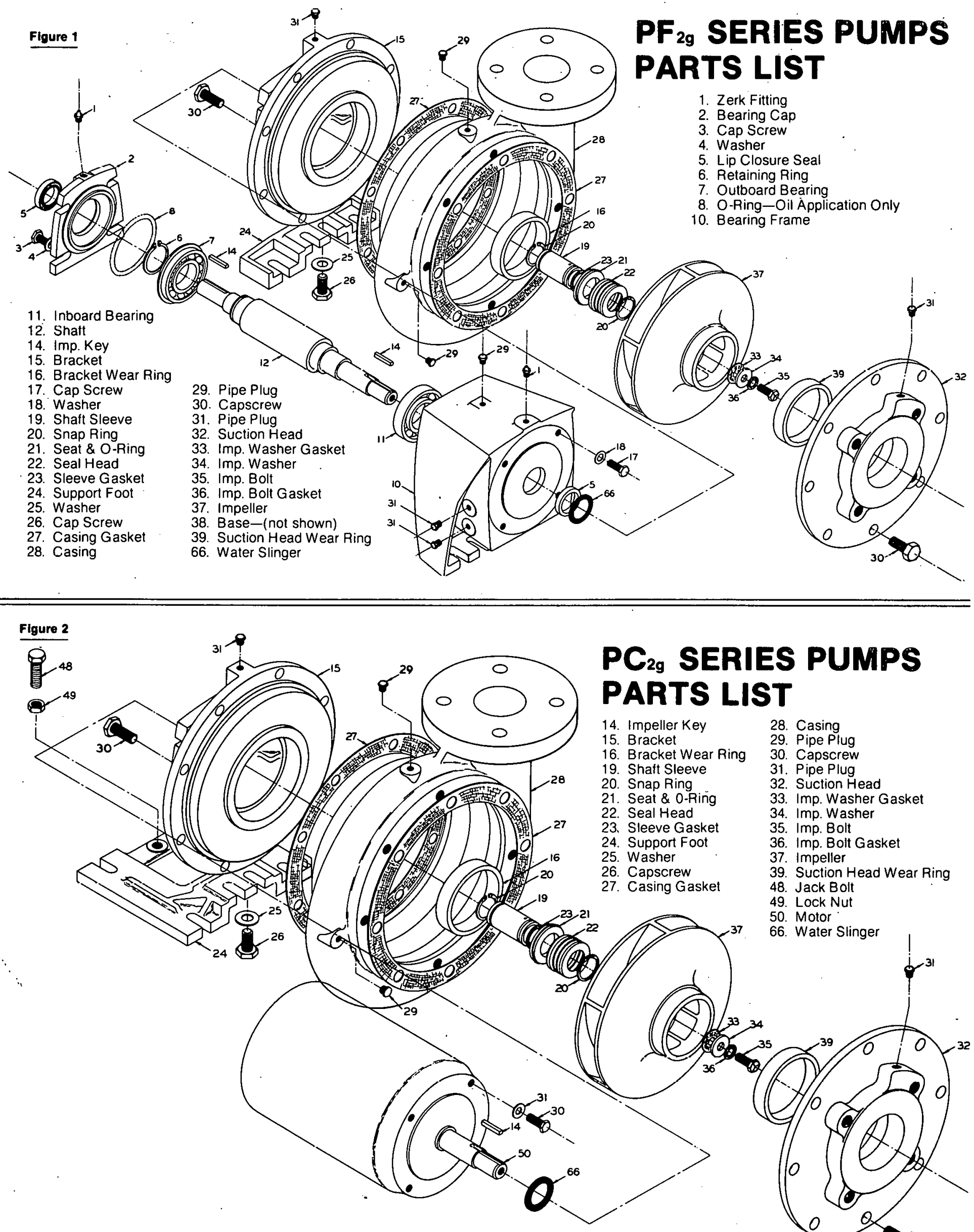


\section{THOOELEF}

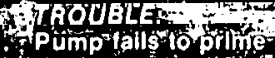

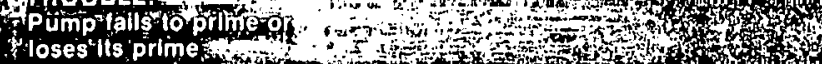

\section{probable cause}

b. Suction strainer is clogged

c. Suction lift is too high

d. Defective priming valve

e. Defective packing or seal a. Air leaks in suction lines

\section{REMEOY}

a. Clean and tighten all suction connections; relocate suction inlet in liquid source.

b. Remove dirt, leaves or other materials from strainer.

c. Re-evaluate pump requirements and correct suction conditions accordingly.

d. Replace valve.

e. Replace packing or seal.

\section{it TROUELE

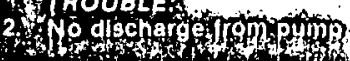

PROBABLE CAUSE

b. Total head is too high

c. Driver is not operating at rated speed

d. Impeller or discharge line is clogged

e. Wrong direction of rotation

Pump is vapor bound a. Pump is not properly primed

\section{REMEDY}

a. Reprime the pump; refer to priming troubles and remedies.

b. Re-evaluate head calculations; measure elevation differences between pump and liquid source, and pump and discharge point

c. Check voltage of electric motor; check steam pressure of sleam turbine; check engine R.P.M.'s. Refer to applicable maintenance manuals for possible troubles and corrective action.

d. Back flush pump to clear obstruction; disassemble pump and/or piping and remove obstruction.

e. Check wiring against diagram on motor name plate and in controller; reverse any two power leads on a three-phase motor; replace a single phase motor.

f. Provide additional pressure on liquid being pumped by elevating liquid sourcet or pressurlzing the supply tank

TAOUELE

3. Pump does not deliver rated capacily

\section{PAOBABLE CAUSE}

a. Pump is not properly primed

b. Suction lift is too high

c. Excessive air in liquid

d. Air leakage through stuffing box

e. Driver is not operating at rated speed

f. Impeller is clogged

g. Wearing rings are worn

h. Impeller is damaged

i. Pump is vapor bound

g. Replace wearing rings.

\section{REMEDY}

a. See 2.a. ahove

b. See 1.c. above

c. See 1.a. above.

d. See 1.e. above

e. See 2.c. above

f. See 2.d. above

h. Replace impeller.

i. See 2.f. above.

\section{TROUBLE}

\section{Insulficient pressure}

\section{PROBABLE CAUSE}

a. Excessive air in liquid

b. Drive is not operating at rated speed

c. Wrong direction or rotation

d. Total head is too high

e. Wearing rings are wuri

. Impeller is damaged

g. Casing gasket is defective allowing internal leakage

1.. Liquiu is vapurizing

a. See 3.c. above

b. See 2.c. above.

c. See 2.e. above

d. See 2.b. above.

e. See 3.g. above

f. See 3.h. above

g. Replace casing gasket

h. See 2.f. above.

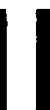

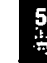
Pump starts then stops

\section{PROBABLE CAUSE}

a. Air leaks in suction line

b. Air pocket in suction line

c. Water seal line is plugged

d. Excessive air in liquid

e. Suction lift too high

g. Pump is vapor bound f. Defective packing or seal

\section{REMEDY}

b. Reprime the pump; eliminate air pocket conditions.

c. Remove obstruction from water line.

d. See 1.a. above.

e. See 1.c, above.

f. See 1.e above.

g. See 2.t. above. a. See 1.a. above.

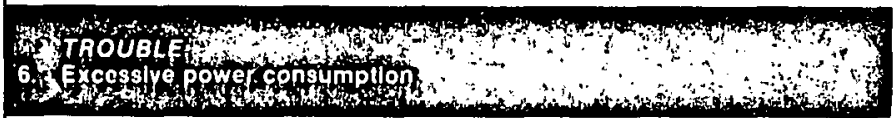

\section{PAOBABLE CAUSE}

a. Speed is too high

b. Wrong direction of rotation

c. Total head is too high

d. Total head is to low

e. Impeller is clogged

Impeller is binding

g. Motor shaft is bent or worn

h. Driver and pump are misaligned

Power frame shaft is bent

Wearing rings are worn

$k$. Packing is incorrectly installed

\section{REMEOY}

a. Internal electric motor wiring is incorrect; replace motor; refer to appliçable driver maintenance manuals for possible troubles and corrective action.

b. See 2.e. above.

c. See 2.b. above

d. Re-evaluate head conditions; correct as required.

e. See 2.d. above.

f. Relieve strain on casing; adjust impeller clearance.

g. Replace motor shaft.

$\mathrm{h}$. Realign driver with pump.

i. Replace shaft.

. See 3.g. above.

k. Install packings correctly: replace if necessary.

\section{THOUELE}

7. Pump is noisy or has excessive vibration

\section{probable cause}

a. Magnetic hum

b. Motor bearings are worn

c. Foreign material in impeller

d. Impeller is binding

e. Motor shaft is bent or worn

f. Driver and pump are misaligned

g. Power trame shaft is bent

h. Foundation is not rigid

Worn bearing in power trame

Impeller is damaged

k. Lack of lubrication in power frame

I. Pump is not properly leveled

$\mathrm{m}$. Piping is not supported

n. Pump is cavitating

\section{REMEDY}

a. Consult motor manufiacturer.

b. Replace bearings.

c. Remove foreign material.

d. See 6.f. above.

e. See 6.g. above

See 6.h. above

g. See 6.i. above

h. Strengthen foundation; change

i. Replace bearing

j. See 3.h. above.

k. Lubricate power frame bearings: replace bearings if damaged.

I. Check levelness of pump.

m. Provide support for suction and discharge piping.

n. Re-evaluate pump appliclation. method of mounting pump unit

\section{RECERIS \\ DEC 5 1977}




\section{THRUSH}

\section{FIELD PUMPTESTING}

Subject: Establishing Pump Capacity from a Pump Performance Curve.

Frequently it is necessary to perform a field pump test to substantiate the operating conditions of a particular pump. A completc pump test requires liead, capacity and horsepower measurements; however, in most instances the equipment necessary to perform the required test is not available. Therefore, it is necessary to obtain as much data as possible with the equipment at hand.

The operating capacity of a pump can be established in the field by measuring the total dynamic head at the operating point and comparing it to the manufacturers pump performance curve. This test requires a minimum of equipment, as all that is necessary is a suction gauge, a discharge gauge and a performance curve. Catalog curves are based on laboratory tests and reference pump pressure to (feet of water) at $60^{\circ} \mathrm{F}$. Therefore, in order to obtain correct capacity it is necessary to convert all pressure readings to fect of water and determine the total pump head, or (total dynamic head). T.D.H.

T.D.H. is the resultant of all the pressure energy generated by the pump, and is computed as follows:

(A) $\mathrm{TDH}=\mathrm{Hd} \cdot \mathrm{H}_{\mathrm{s}}+\mathrm{G}_{\mathrm{d}}$ (for positive suction head)

(B) $\mathrm{TDH}=\mathrm{Hd}+\mathrm{H}_{\mathrm{S}}+\mathrm{G}_{\mathrm{d}}$ (for negative suction head) $\mathrm{TDH}=$ Total dynamic head in feet

$\mathrm{H}_{\mathrm{d}}=$ Discharge head in feet

$\mathrm{H}_{\mathrm{S}}=$ Suction head in feet

$\mathrm{G}_{\mathrm{d}}=$ Gauge distance in feet

The necessary factors to convert pounds per square inch (P.S.I.) or inches of mercury (In hg) to feet of water are:

Feet of Water $=$ P.S.I. $\times 2.31$

Table 2 S.G.

Feet of Water $=\ln / \mathrm{hg} \times 1.13$

Table 3

P.S.I. = Pounds Per Square Inch

In/hg = Inches of Mercury

S.G. = Specific Gravity

The proper procedure to establish capacity (GPM) of a pump from the TDH with performance curve is: (Ref. Fig. 1)

1. Read \& record the suction \& discharge Gauge readings.

2. Establish liquid specific gravity (Table 1 for water)

3. Convert all gauge readings to feet where necessary (Table 2 \& 3)

4. Compute T.D.H.

5. Compare TDH with appropriate performance curve to establish flow in GPM.

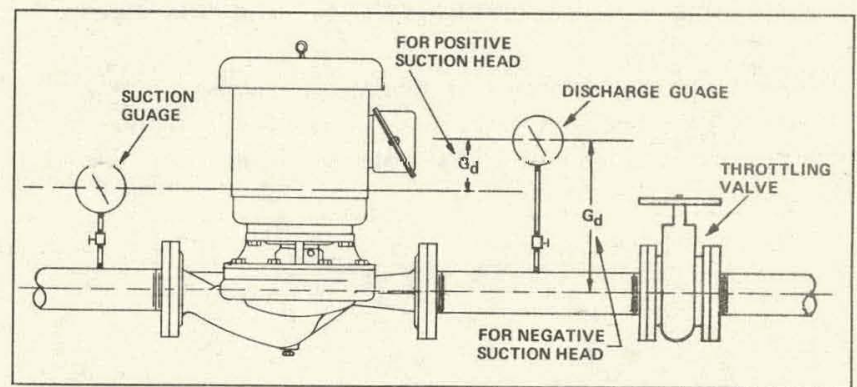

Figure 1.

EXAMPLES:

I. 2TV - $11 / 2$ In-Line Pump for 80 GPM @ 44 TDH with $63 / 4^{\prime \prime}$ impeller diameter.

Check no flow head first to verify correct impeller diameter installed in pump.

No Flow TDH (shut-off head).

Discharge Gauge Reading $=75.8$ psi

Suction Gauge Reading $=55 \mathrm{psi}$

Gauge Dist $=.6$ inches

Operating Temp. $180^{\circ} \mathrm{F} .=$ (S.G. $=.972$ from Table)

Suction head feet $\frac{55 \times 2.31}{972}=130.5$ feet$$
.972
$$

Discharge head feet $\frac{74.5 \times 2.31}{972}=180$. feet

$$
\mathrm{Hd}-\mathrm{Hs}+\mathrm{GD}=\mathrm{TDH}
$$

$=180-130.5+.5=50$ feet

A check of the performance curve (Fig. 2) indicates a 6 3/4" impeller diameter will develop 50 feet TDH@ no flow, therefore, it is confirmed that the correct impeller diameter has been installed in the pump.

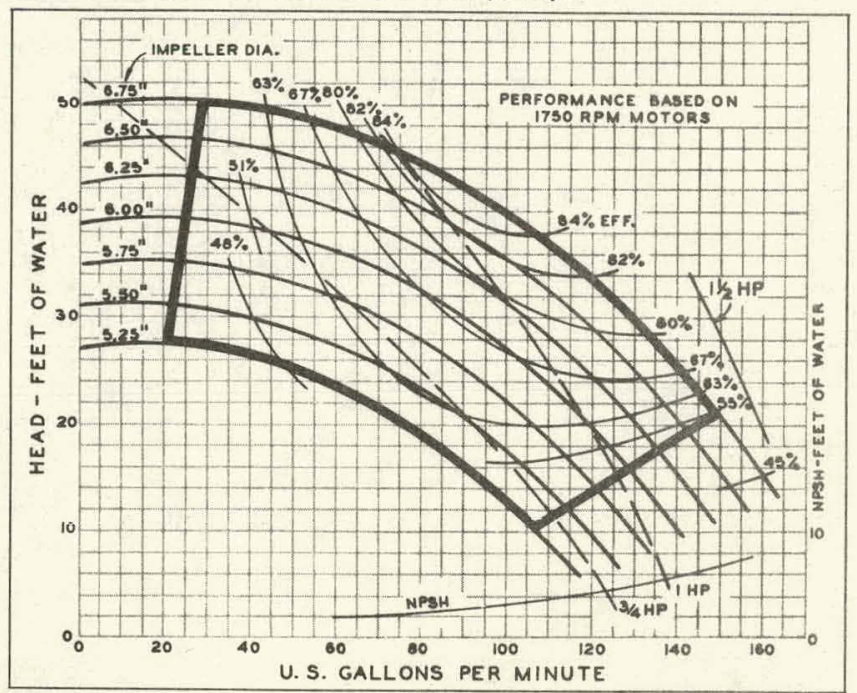

Figure 2. 
11 Establishing Pump Capacity

Discharge Gauge Reading 74.2 PSI

Suction Gauge Reading 54 psi

Gauge Distance .6 in.

Suction head feet $\frac{54 \times 2.31}{.972}=128.2$

Discharge head feet $\underline{74.2 \times 2.31}=171.7$

$$
.972
$$

$\mathrm{H}_{\mathrm{d}}-\mathrm{H}_{\mathrm{s}}+\mathrm{G}_{\mathrm{d}}=\mathrm{TDH}$

$171.7-128.2+.5=44 \mathrm{TDH}$

Referring to the performance curve, $63 / 4$ impeller diameter, follow the curve to 44 feet, read directly below on the gallons per minimum scale to find the pump capacity is 80 GPM.

The accuracy of this test is dependent upon the accuracy with which the measurements are taken, the instruments themselves, and the TDH computations, therefore, $\pm 5 \%$ over all accuracy should be allowed.
Table 2

Table for Converting

Pressure, Lb per Sq In. to Feet (Head) of Water

$\mathrm{ft}=2.31 \times \mathrm{lb} / \mathrm{sq}$ in.

\begin{tabular}{|c|c|c|c|c|c|c|c|c|c|c|c|}
\hline 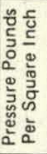 & 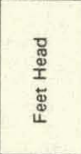 & 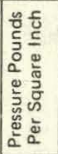 & 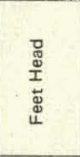 & 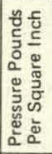 & 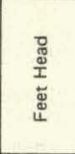 & 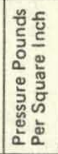 & 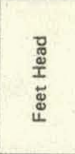 & 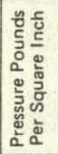 & 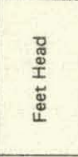 & 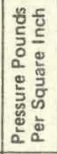 & 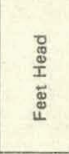 \\
\hline 1 & 2.31 & 53 & 122.43 & 105 & 242.55 & & 362.67 & 209 & 482.79 & & \\
\hline $\begin{array}{l}2 \\
3\end{array}$ & 6. & $\begin{array}{l}54 \\
55\end{array}$ & 12 & \begin{tabular}{|l|}
106 \\
107
\end{tabular} & 2 & $\begin{array}{l}158 \\
159\end{array}$ & 8 & \begin{tabular}{|l}
210 \\
211
\end{tabular} & & 262 & \\
\hline 4 & $\begin{array}{r}9.23 \\
.9 .25\end{array}$ & 56 & 129.36 & 108 & 249.48 & 160 & 369.60 & 212 & $\begin{array}{l}488.41 \\
489.72\end{array}$ & 264 & $\begin{array}{l}607.53 \\
609.84\end{array}$ \\
\hline & $\begin{array}{l}11,55 \\
1386\end{array}$ & $\begin{array}{l}57 \\
58\end{array}$ & $\begin{array}{l}131.67 \\
1320\end{array}$ & 109 & 251.79 & 161 & 371 & 213 & & 265 & 612.15 \\
\hline & $\begin{array}{l}33.86 \\
16.17\end{array}$ & $\begin{array}{l}58 \\
59\end{array}$ & $\begin{array}{l}133.98 \\
136.29\end{array}$ & $\begin{array}{l}110 \\
111\end{array}$ & $\begin{array}{l}254.10 \\
256.4\end{array}$ & 162 & 374 & \begin{tabular}{|l}
214 \\
214
\end{tabular} & & 266 & 614.46 \\
\hline 8 & 18.48 & 60 & 138.60 & 112 & 258.72 & $\begin{array}{l}163 \\
164\end{array}$ & $\begin{array}{l}375.53 \\
378.84\end{array}$ & $\begin{array}{l}21 \\
21\end{array}$ & $\begin{array}{l}496.65 \\
498.96\end{array}$ & $\begin{array}{l}267 \\
268\end{array}$ & $\begin{array}{l}616.77 \\
619\end{array}$ \\
\hline & 20. & 61 & 140.91 & 113 & 261.03 & 165 & 381.15 & 217 & & 269 & $\begin{array}{l}619.08 \\
621.39\end{array}$ \\
\hline 11 & $\begin{array}{l}23.11 \\
25.4\end{array}$ & 62 & $\begin{array}{l}143.22 \\
14553\end{array}$ & 114 & & 166 & & 218 & & 270 & $\begin{array}{l}621.39 \\
623.70\end{array}$ \\
\hline & 25.4 & $\begin{array}{l}63 \\
64\end{array}$ & $\begin{array}{l}145.53 \\
147.84\end{array}$ & $\begin{array}{l}115 \\
116\end{array}$ & $\begin{array}{l}265.65 \\
26796\end{array}$ & $\begin{array}{l}167 \\
168\end{array}$ & & $\begin{array}{l}219 \\
220\end{array}$ & & 271 & 626 \\
\hline & & 65 & 150.15 & $\begin{array}{l}1166 \\
117\end{array}$ & $\begin{array}{l}267.96 \\
270.27\end{array}$ & $\begin{array}{l}168 \\
169\end{array}$ & 388. & $\begin{array}{l}220 \\
221\end{array}$ & & $\begin{array}{l}272 \\
273\end{array}$ & 628.32 \\
\hline 15 & $\begin{array}{l}\begin{array}{r}32.34 \\
34.65\end{array} \\
3\end{array}$ & $\begin{array}{l}66 \\
67\end{array}$ & $\begin{array}{l}152.46 \\
154.77\end{array}$ & 118 & 272.58 & 170 & & 222 & 5 & 274 & 30.63 \\
\hline & $\begin{array}{l}36.96 \\
30.96\end{array}$ & 68 & 157.08 & $\begin{array}{l}119 \\
120\end{array}$ & $\begin{array}{l}274 \\
277 .\end{array}$ & \begin{tabular}{|l}
171 \\
172
\end{tabular} & $\begin{array}{l}01 \\
32 \\
32\end{array}$ & $\begin{array}{l}223 \\
224\end{array}$ & 51 & $\begin{array}{l}2755 \\
276\end{array}$ & $\begin{array}{l}635.25 \\
6375\end{array}$ \\
\hline 18 & $\begin{array}{l}39.27 \\
41.58\end{array}$ & 70 & $\begin{array}{l}159.39 \\
161.79\end{array}$ & 121 & 279 & 173 & & 225 & & 277 & 37.56 \\
\hline 15 & & 71 & $\begin{array}{l}16 \\
16\end{array}$ & $\begin{array}{l}22 \\
23\end{array}$ & $\begin{array}{l}28 \\
28\end{array}$ & \begin{tabular}{|l}
174 \\
175
\end{tabular} & & $\begin{array}{l}226 \\
227\end{array}$ & & 9 & 642.18 \\
\hline & 46.2 & 72 & 166.32 & 24 & & 176 & & 228 & & 280 & $\begin{array}{l}644.49 \\
646.80\end{array}$ \\
\hline & $\begin{array}{l}48 . \\
50 .\end{array}$ & $\begin{array}{l}73 \\
74\end{array}$ & 168.63 & 125 & & 177 & 40 & 229 & & 281 & 80 \\
\hline & $\begin{array}{r}50.82 \\
53113\end{array}$ & $\begin{array}{l}44 \\
75\end{array}$ & & 126 & & 178 & 411. & $\begin{array}{l}230 \\
2301\end{array}$ & & 282 & 51 \\
\hline & & 7 & & 88 & & 180 & & & & 283 & 3 \\
\hline & & & & & & 18 & & & & ${ }_{5}^{4}$ & 60 \\
\hline & 60 & 78 & 18 & 30 & & 182 & & & & $\begin{array}{l}285 \\
286\end{array}$ & \\
\hline & & 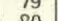 & & 131 & & 183 & & & & 287 & 600 \\
\hline & & & & & & 18. & & & & 208 & \\
\hline & & & & & & 18 & & & & & 667 \\
\hline & 71 & 8 & 10 & 135 & & $18 \%$ & & & & & $\begin{array}{l}659 \text { an } \\
672.2\end{array}$ \\
\hline & & & & 136 & & 18 & & & & & 6 \\
\hline & 76. & 85 & & & & 18 & & & & & 676.83 \\
\hline & & & & 38 & & 19 & & & & & 679.14 \\
\hline 36 & & & & 139 & & & & & & & 681.45 \\
\hline 3 & & 8 & & 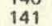 & & $\begin{array}{l}192 \\
193\end{array}$ & & & & & 583 \\
\hline & 87. & & 207.90 & 142 & & 194 & & 40 & & 298 & \\
\hline & & 91 & & 143 & & 19 & & & & 299 & \\
\hline & 92 & 93 & & $\begin{array}{l}144 \\
145\end{array}$ & $\begin{array}{l}33 \\
33\end{array}$ & $\begin{array}{l}196 \\
197\end{array}$ & $\begin{array}{r}452.76 \\
445.07\end{array}$ & 48 & $\begin{array}{l}572.88 \\
575.18\end{array}$ & & 693.00 \\
\hline & & 0 & & & & 19 & & & & & \\
\hline & & & & & & 10 & & & & & \\
\hline & & 96 & & & & & & & & & \\
\hline & & & & & & 20 & & & & & \\
\hline & & & & & & & & & & & \\
\hline & & & & & & 204 & & & & & \\
\hline & & & & & & & & & & & \\
\hline & & 10 & & & & 206 & & & & & \\
\hline 52 & $\begin{array}{l}117.81 \\
12012\end{array}$ & $\begin{array}{l}103 \\
104\end{array}$ & $\begin{array}{r}237.93 \\
24024\end{array}$ & $\begin{array}{l}155 \\
156\end{array}$ & $\begin{array}{l}358.05 \\
360.36\end{array}$ & $\begin{array}{l}207 \\
208\end{array}$ & $\begin{array}{l}478.17 \\
480.48\end{array}$ & $\begin{array}{l}259 \\
260\end{array}$ & $\begin{array}{l}598.29 \\
600.60\end{array}$ & & \\
\hline
\end{tabular}

Table 3

Table for Converting

Inches of Mercurv to Feet of Water $\mathrm{ft}=1.133 \mathrm{x}$ in hg

Inches of Mercury in Tenth

\begin{tabular}{|c|c|c|c|c|c|c|c|c|c|c|}
\hline & 0 & .1 & .2 & .3 & .4 & .5 & .6 & .7 & .8 & .9 \\
\hline 1 & 1.133 & 1.246 & 1.359 & 1.473 & 1.586 & 1.699 & 1.813 & 1.925 & 2.039 & 2.153 \\
\hline 2 & 2.266 & & 2.492 & & & & & & 3.172 & 3.286 \\
\hline 3 & 3.399 & 3.512 & 3.625 & 3.74 & 3.85 & 3.965 & 4.08 & 4.19 & 4.3 & 4.42 \\
\hline 4 & 4.532 & 4.645 & 4.76 & 4.87 & 4.985 & 5.1 & 5.21 & 5.325 & 5.44 & 5.55 \\
\hline 5 & 5.665 & 5.78 & 5.89 & 6.00 & 6.12 & 6.23 & 6.344 & 6.46 & 6.57 & 6.684 \\
\hline 6 & 6.798 & 6.91 & 7.024 & 7.138 & 7.25 & 7.364 & 7.48 & & 7.7 & 7.817 \\
\hline 7 & 7.931 & 8.044 & 8.157 & 8.27 & 8.384 & 8.497 & 8.61 & 8.72 & 8.84 & 8.95 \\
\hline 8 & 9.064 & 9.177 & 9.29 & 9.40 & 9.517 & 9.63 & 9.74 & 9.857 & 9.97 & 10.088 \\
\hline 9 & 10.197 & 10.31 & 10.42 & 10.536 & 10.65 & 10.76 & 10.87 & 10.99 & 11.10 & 11.216 \\
\hline 10 & 11.33 & 11.443 & 11.556 & 11.67 & 11. & 11.896 & 12. & 12.123 & 12.236 & 12.35 \\
\hline 11 & 12.46 & 12.576 & 12.69 & 12.80 & 12.91 & 13. & 13.142 & 13.256 & 13.37 & 13.483 \\
\hline 12 & 13.596 & 13.71 & 13.82 & 13.935 & 14.05 & 14.162 & 14.275 & 14.39 & 14.50 & 14.615 \\
\hline 13 & 14.73 & 14.84 & 14.95 & 1507 & 15.18 & 15.295 & 15.408 & 15.522 & 15.635 & 15.748 \\
\hline 14 & 15.86 & 15.975 & 16.088 & 16 & 16.315 & 8 & 16. & 16. & 16. & 16.88 \\
\hline $1 \mathrm{~b}$ & 16.99 & +7.108 & 17.22 & 17.335 & 17.49 & 17.561 & 17.674 & 17.788 & 17. & 18.014 \\
\hline 16 & 18.13 & 18.24 & 18.354 & 18.467 & 18.58 & 18.694 & 18. & 18.92 & 19.034 & 19.147 \\
\hline 17 & & 19.3 & 7 & 19. & 19.714 & & & & & 20.28 \\
\hline 18 & 20.39 & 20.51 & 20.6 & 20.7 & 20.847 & 20.9 & 21.07 & 21.187 & 21. & 21,41 \\
\hline 19 & 21.53 & 21.64 & 21.753 & 21.866 & 21.8 & & 22. & 22.317 & 22 & 22.543 \\
\hline 20 & & & & 22.9 & & 23 & 23. & & & 23. \\
\hline 21 & & & 2 & 24.1 & 24.243 & 24.3 & 24. & 24.583 & 24. & 24.81 \\
\hline 22 & 24.926 & 25.04 & 25.152 & 25.265 & 25.38 & 25.5 & 25 & 25.7 & 25. & 25.945 \\
\hline 23 & 26.0 & 26.17 & 26.28 & 26.398 & 26. & & 26. & 26.8 & & 27.078 \\
\hline 24 & 27.2 & 27.305 & 27.418 & 27.53 & 27.645 & 27. & 27.8 & 27.985 & 28.098 & 28.21 \\
\hline 25 & 28.325 & 28.438 & 28.55 & 28.66 & 28.78 & 28.8 & & 29.118 & 29.2 & 29.344 \\
\hline 26 & 29.46 & 29.572 & 29.685 & 29.798 & 29.91 & 30.025 & 30.138 & 30.25 & 30.365 & 30.478 \\
\hline 27 & 30.6 & 30.705 & 30.82 & 30.93 & 31.04 & 31. & 31.27 & 31.385 & 31.498 & 31.61 \\
\hline 28 & 31.7 & 31.84 & 31. & 32.0 & 32.18 & 32.2 & 32. & 32. & 32. & 32.744 \\
\hline $\begin{array}{l}29 \\
30\end{array}$ & $\begin{array}{l}32.86 \\
33.99\end{array}$ & 3 & $=$ & 33. & & 33.413 & 33.526 & 33.64 & 33.753 & 33.866 \\
\hline
\end{tabular}


APPENDIX E

THRUSH CIRCULATING PUMPS

E-i 
 \\ MODEL R \& RB THRUSH CIRCULATORS
}

REPLACEMENT FOR IRON AND BRONZE

\author{
B\&G 100 Sorlos \\ Taco UN 110 Series \\ Armstrong S-25 Serles
}

Model R or RB THRUSH CIRCULATOR capacities are comparable to the above Series.

Body length (A) Figure 1, is identical with the Models listed above; therefore, piping does not have to be changed to install THRUSH MODEL $R$ OR $R B$ CIRCULATORS.

\section{INSTALLATION}

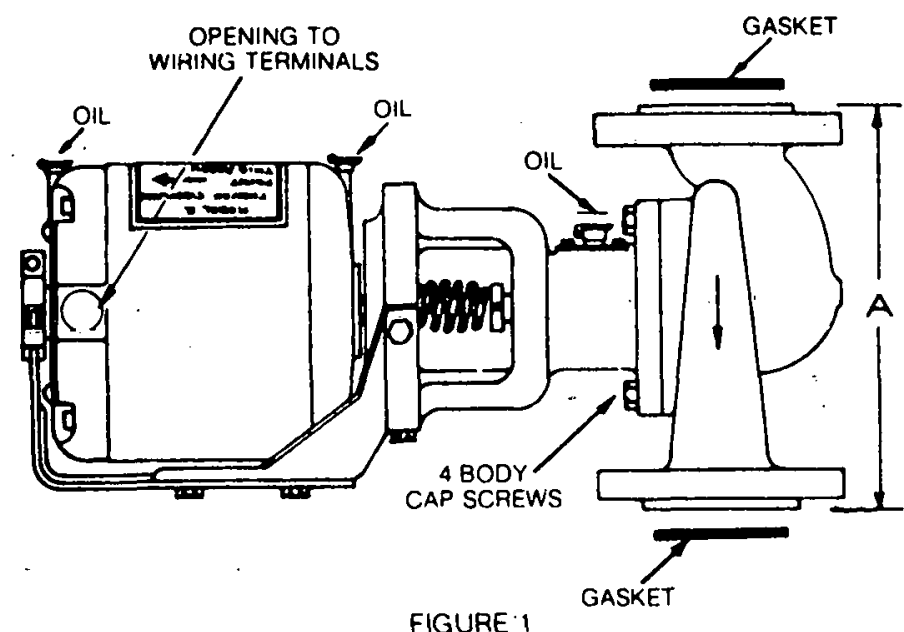

FOR HORIZONTAL FLOW

Model R or RB Circulators are shipped from factory with body mounted for downward flow as shown in Figure 1. If Circulator boidy is to be placed in a horizontal pipe, remove 4 body Cap Screws and turn the Circulator body only to right or left (figure 2) depending on direction of horizontal flow. DO NOT TURN MOTOR OR BRACKET ASSEMBLY. All 3 vil cups must always be UP as shown in Figure 1. If Circulator is to pump upward in a vertical pipe line, remove 4 Body Cap Screws and turn the Circulator body only $180^{\circ}$. Model R or RB may be installed in a vertical line to pump up or down and may be installed in a horizontal pipe line to pump left or right by turning the Circulator body as required. Motor and Bracket Assembly oil cups must always be UP as shown in Figure 1.
Simply disconnect the wiring to the original Circulator and remove the four flange bolts holding the Circulator in the pipe line. Pull the original Circulator out of the line and insert the new Mndel R or RB, with its new flange gaskets, into the line. Bolt the Model R or RB firmly into position with the original flanges, nuts and bolts. The 2 bolt competitors flanges are the same as the Model R or RB so the original flanges do not have to be removed.

Oil all 3 oil cups before starting and every 3 months thereafter. Use S.A.E. \# 20 non-detergent oil for motor, and \#30 nondetergent oll for bracket. For high temperature or continuous operation, more frequent oiling will be necessary. Also make sure system pressure is 12 lbs. or more before starting circulator.

\section{WIRING}

Model $R$ or RB Circulator motors have openings for $B X$ connector and 2 wiring posts under terminal cover. Be sure 2 lead wires are securely fastened under terminal nuts. DO NOT CON. NEC 'i SOLID CONDUIT TO CIRCULATOR MOTOR. Use 18" of flexible between end of conduit and motor. Motor is built for $115 \mathrm{v}, 60 \mathrm{c}$, 1 phase current.

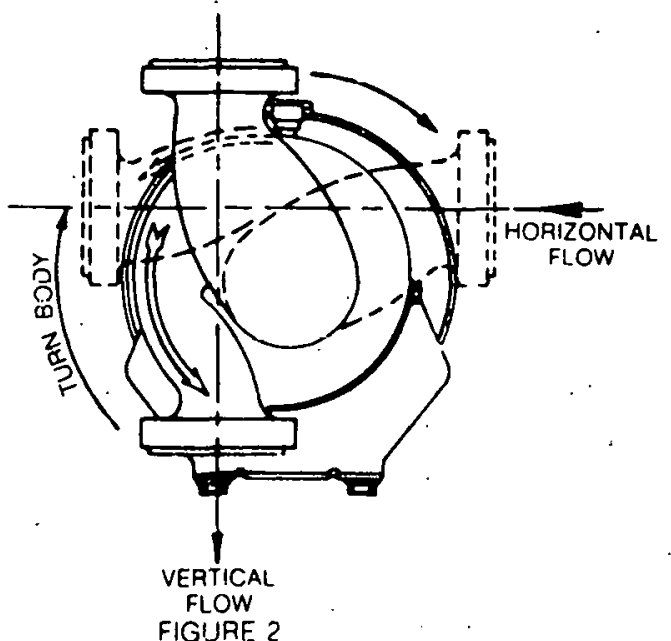


APPENDIX F

STEEL AQUATOWERS

$\mathbf{F}-\mathbf{i}$ 


\section{MARLEY}

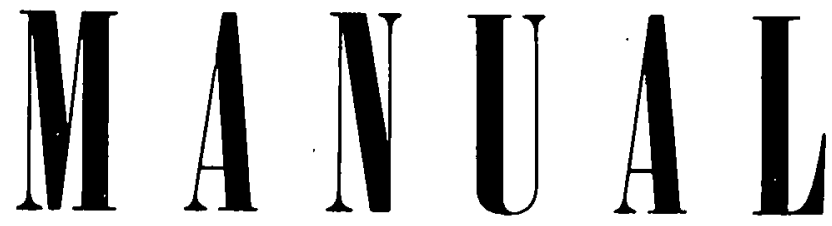

Installation, Operation

and

Maintenance Instructions

SERIES 4600

STEEL AQUATOWERS 
F-2

THIS PAGE

WAS INTENTIONALLY

LEFT BLANK 


\title{
Installation, Operation and Maintenance Instructions
}

\author{
SERIES 4600 \\ STEEL AQUATOWERS
}

\section{TOWER LOCATION}

Locate so prevailing wind will blow into the louvered face. Direct fan discharge away from-building surfaces to eliminate the possibility of discoloration. Locate so there is free flow of air to and from the tower. Allow clearance on all sides for maintenance. Anchor in a level position to a stable foundation.

\section{INDOOR INSTALLATION}

$A$ duct is required from the tower air discharge to the outside. In some cases it may also be desirable to install an inlet air duct. If ducts are used, the total draft loss should not exceed .10' water pressure. Draft losses can be minimized by:

a. Using $\mathbf{2 0 \%}$ oversize ducts.

b. Avoiding sharp turns or abrupt changes in size.

c. Keeping duct length to a minimum:

d. Increasing the area of screened or louvered opening so the net free area is at least $20 \%$ greater than the tower discharge opening area.

Ducts should be attached to the tower using rubber or canvas connections. Access openings for servicing the mechanical equipment must be provided if air discharge ducts are installed. If the duct discharges into the prevailing wind, it. may be necessary to install a windbreak or an elbow to serve as a deflector. Ducts installed on towers with year around usage should be water tight and insulated to prevent condensation.

\section{TOWER INSTALLATION}

The tower is shipped complete with the motor in a carton and miscellaneous parts package within the tower. Anchor tower by bolting a clip to the foundation and basin sides or through slots in legs using $3 / 8^{\prime \prime}$ or larger bolts.

PIPING TO TOWER (Summer Temperature Conditions) 1. Use pipes of sufficient size to provide.minimum friction loss.

2. Connect Float Valve to make-up water supply.

3. Install bleed-off line. Bleed-off is the continu ous wasting of a small amount of water during operation which retards scale and corrosion. A bleed-off line can be installed at any point in the system, however, the best point is in the hot water line near the top of the tower so water will be removed when the pump is operating. A copper tube, pinched down or with a pet cock can be used.

\section{PIPING TO TOWER (Winter Freezing Conditions)}

1. Where operating conditions require tower use during freezing weather, it is recommended that the towers be installed for "dry basin" operation. See Figure 1.

2. Provide an inside open-type storage tank with a capacity of four times the cooling tower GPM.

3. Connect tower suction to storage tank.

4. Install make-up water, bleed-off, overflow and drain lines on tank.

5. Insulate and heat water lines exposed to freezing temperatures. 


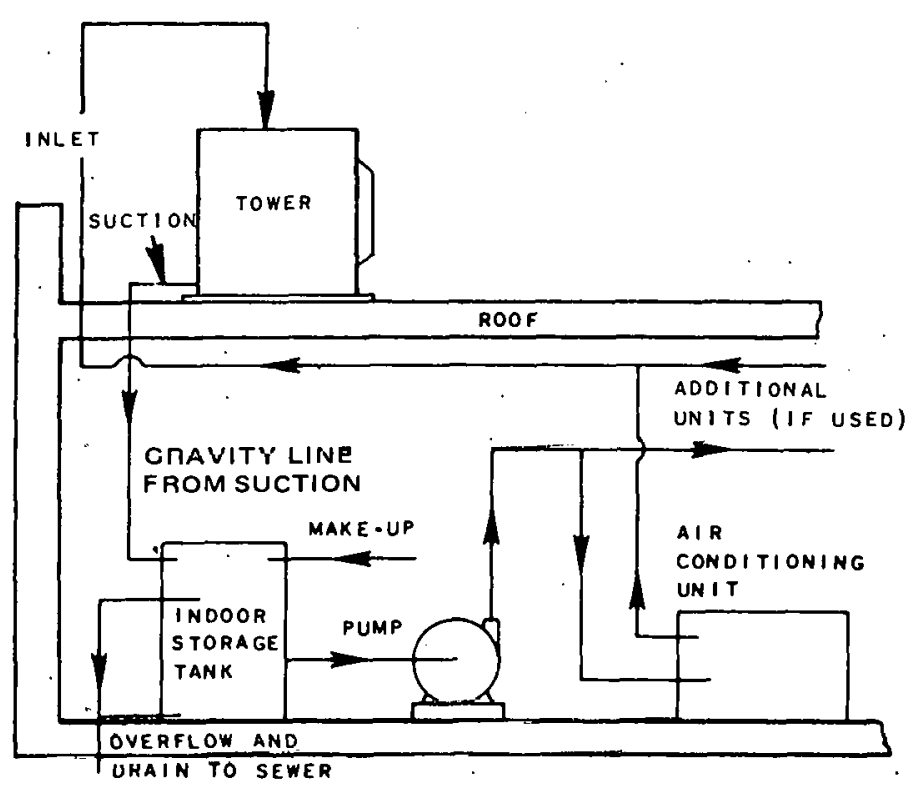

FIGURE 1. Flow Diagram for a Cooling Tower with Indoor Storage Tank. (Piping Is Arranged So I hat Tower Basin Will Drain When Pump /s Shut Off.)

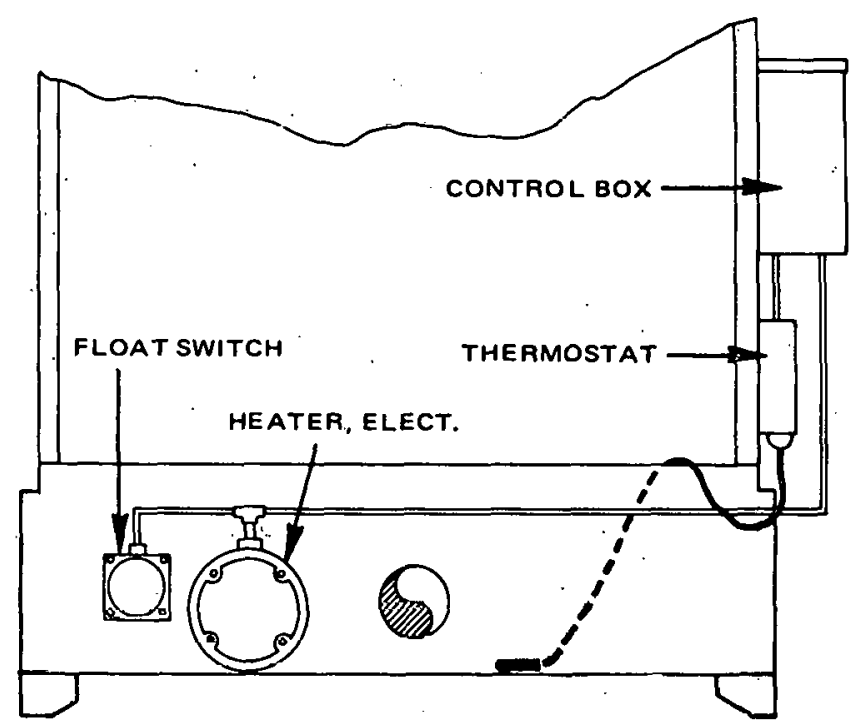

FIGURE 2. Elentric heater systcms are available as optional equipment to prevent fresaing the cold water basin when it cannot be drained.

\section{MECHANICAL EQUIPMENT INSTALLATION}

\section{MOTOR, SHEAVE AND V-BELT INSTALLATION}

1. Check the motor name plate to be sure its voltage, phase and frequiency ratings are the same as the power supply.

2. Check to insure that fan is tightly seriured to bearing housing shaft and free to rotate and that bearing housing is secure to support.

3. Install all thread belt tension adjusting bolts in motor base cradle, see Detail $A$. Install lock washers and nuts, fastening adjusting bolts to motor base cradle. Run galvanized nuts about halfway down on bolts. Insert bolts through slots in motor base, install lock washers and run top nuts down, locking base in place. Bolt motor to motor base.

4. Install motor sheave and align it with fan sheave. A plumb line will be helpful in aligning sheaves. See Detail "B".

5. Install $V$-belt and adjust tension by means of belt tension adjusting bolts. A correctly tensioned belt does not slip when the fan is started; and, when running, the "tight" side is straight between sheaves. The "slack" side will have a slight bow: Correct tension can only be determined by trial runs at successively higher tensions until slipping has stopped.

A small further increase in tension should be madé to account for normal belt stretch. Avoid over tensioning. Too much tension reduces bearing and belt life.
New belts must be retensioned after 8 to 12 hours operation since new belts stretch at a higher rate and "seat" into sheave grooves.

6. Connect motor to power supply using wiring, switching, short circuit protection and overload protection in atcordance with the National Electric Code and local requirements. Failure to wire the motor correctly will void its warranty. The overload protection for Motors must be part of the control system, see Diagram " $\mathrm{C}$ ".

7. Sleeve bearing motors are usually shipped without oil and must be oiled before operating. Ball bearing motors are lubricated for the initial operation by the manufacturer.

8. Install belt guard using sheet metal screws. See Figure 3 (page 8).

\section{INSTALLATION OF OPTIONAL EQUIPMENT}

\section{AIR INLET SCREEN}

Install hardware used to attach air inlet screen to side casing sheets. Set screen in position and install with wing nuts.

\section{HOT WATER BASIN COVER}

Install "S" strips at hot water basin sides. Remove from splash box cover those sheet metal screws indicated on installation drawing. Position basin cover segments and reinstall sheet metal screws. 


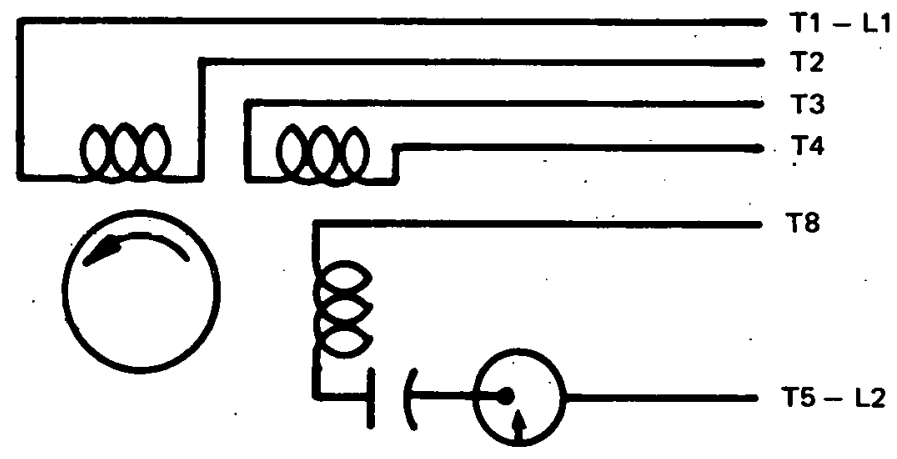

Without Thermal Overload (Integral HP)

\section{HIGH VOLTAGE}

1. Connect $\mathrm{T} 1$ and $\mathrm{L} 1$ and insulate.

2. Connect $T 2, T 3$ and $T 8$ and insulate

3. Connect T4 and T5 and insulate.

\section{LOW VOLTAGE}

1. Connect T1, T3, T8 and L1 and insulate.

2. Connect T2, T4, T5 and $L 2$ and insulate.

NOTE: Colors may be substituted for numbers as follows:

$$
\begin{aligned}
& \text { T1 - Blue } \\
& \text { T2 - White } \\
& \text { T3 - Green } \\
& \text { T4 - Yellow }
\end{aligned}
$$

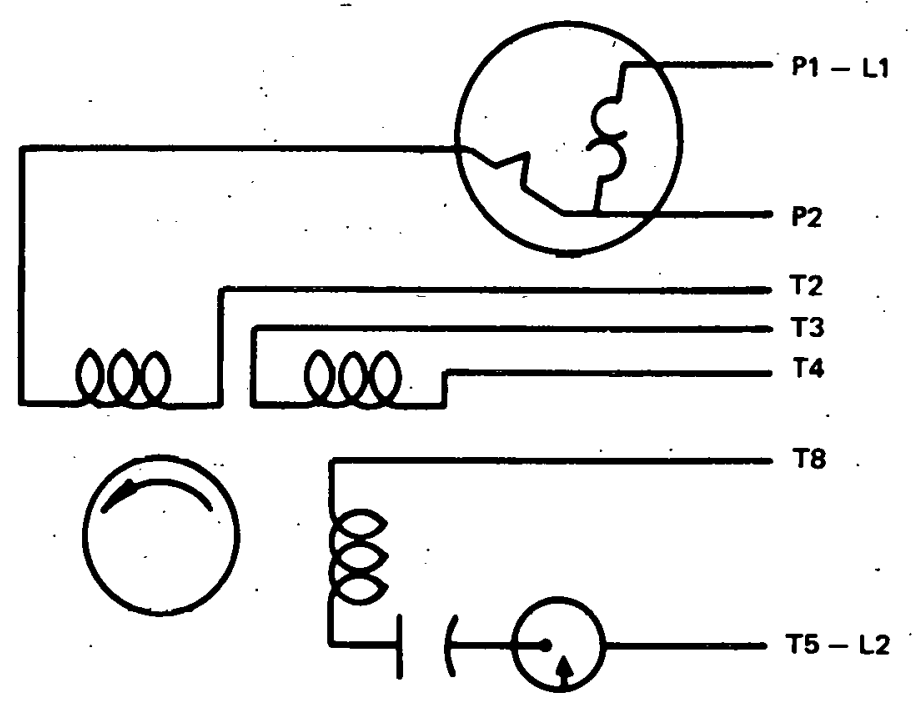

With Thermal Overload (Fractional HP)

HIGH VOLTAGE

1. Insulate P2.

2. Connect T2, T3 and T8 and insulate.

3. Connect T4, T5 and $L 2$ and insulate.

4. Connect $P 1$ and $L 1$ and insulate.

LOW VOLTAGE

1. Connect $P 1$ and $L 1$ and insulate.

2. Connect $P 2$ and $T 3$ and insulate.

3. Connect $\mathrm{T} 1$ and $\mathrm{T} 8$ and insulate.

4. Connect T2, T4 and T5 and insulate.

To reverse rotation, interchange leads T5 and T8.

\section{WIRING DIAGRAM CAPACITOR START MOTORS, REVERSIBLE, DOUBLE VOLTAGE}

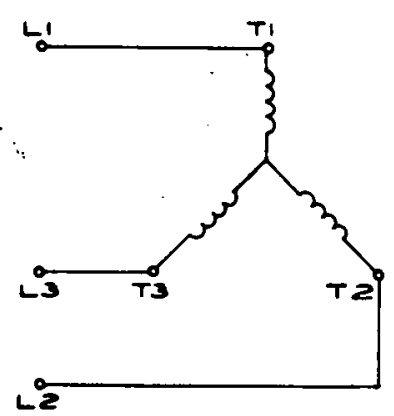

$200 \mathrm{VOHT}$
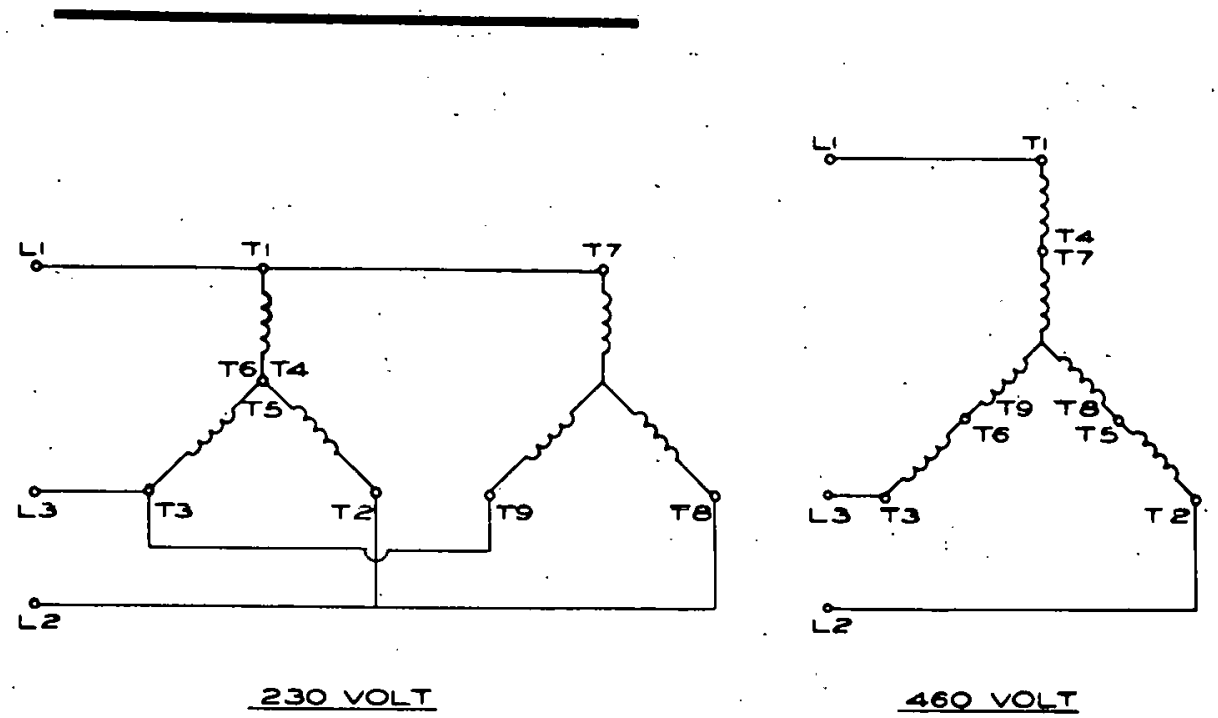

WIRING DIAGRAM 3 PHASE MOTORS 


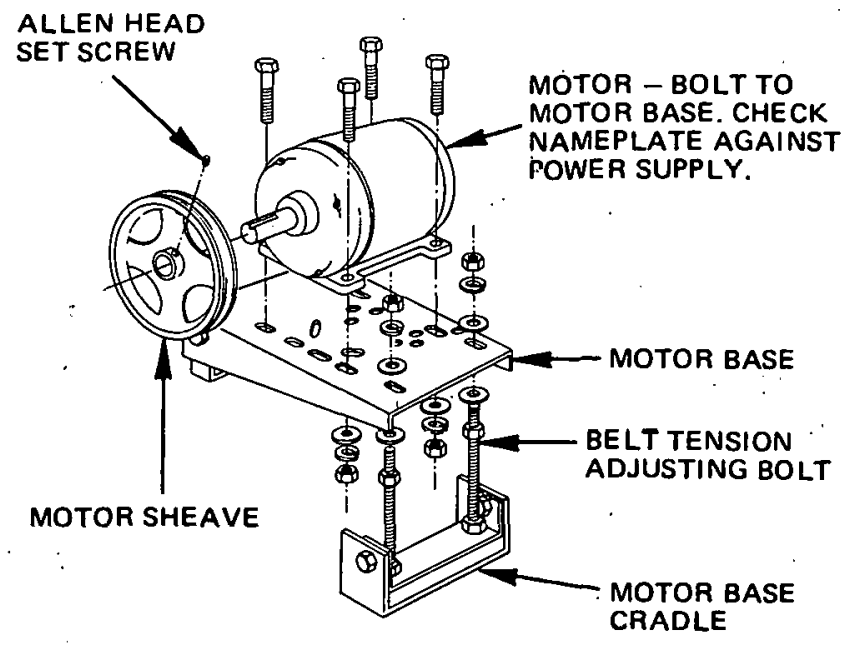

DETAIL "A"

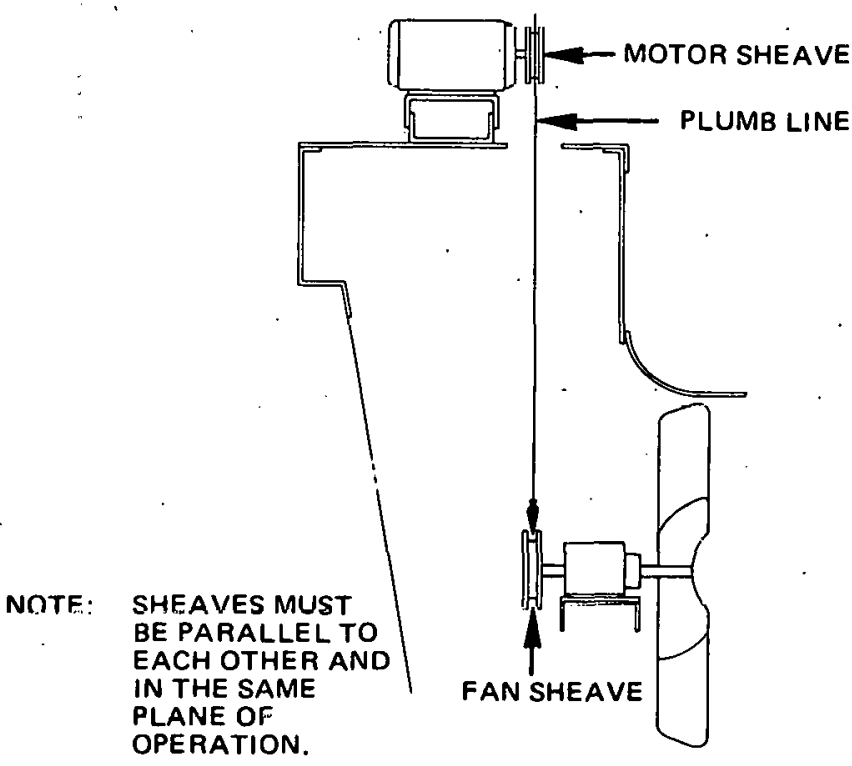

DETAIL "B"

\section{OPERATION INSTRUCTIONS}

1. Wash foreign matter from fill and basin.

2. Fill circulating system with water.

3. Start pump and adjust float valve to maintain $4^{\prime \prime} 15^{\prime \prime}$ on models 4619 thru 4625 and $8^{\prime \prime}$ on models 4627 thru 4633 ) of water in cold water basin.

4. Check bleed-off line to make sure water is being discharged during operation:

5. Check fan for free rotation and oil level in Bearing Housing (see maintenance instructions). Start motor and check direction of rotation. Fan must rotate clockwise when viewed from the fan discharge side. If the rotation

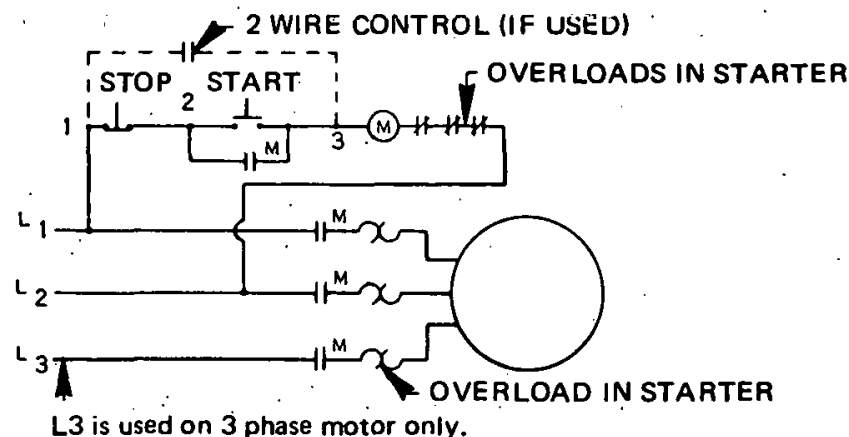

Showing Overload in Starter DIAGRAM" C"

is incorrect, change any two of the three motor leads for a three-phase motor or interchange the connections of either the main or starter windings for single-phase capacitor start motor.

6. Depth of water in hot water basin should be uniform. If the basin overflows, reduce the flow rate. Do not pump more water than design capacity.

7. Do not cycle the motor so that the total of the starting times exceeds $\mathbf{3 0}$ seconds each hour.

\section{MAINTENANCE INSTRUCTIONS}

\section{MOTOR LUBRICATION}

Lubricate the motor according to the motor manufacturer's instructions shipped with the motor. Motor should be relubricated at the start and end of each operating seasson.

\section{FAN BEARING LUBRICATION}

Lubricate bearing housings with SAE 20 mineral oil.

Oil cups should be kept full to insure proper oil level in bearing housings.

\section{BELT TENSION}

Check belt tension every two to three weeks during peak operating season. Refer to page 4, item 5.

\section{BLEED-OFF}

Check the bleed-off for continuous water discharge:

\section{BASIN AND SUCTION SCREEN}

Drain and clean cold water basin and suction screen periodically.

\section{FLOAT VALVE}

Check float valve periodically for proper operation and maintenance of water level. 


\section{GENERAL}

The following tables show the proper amount of bleed-off.

COOLING RANGE
DEGREES F

6

$7.1 / 2$

10

15

20

\section{CHEMICAL TREATMENT}

The dissolved solids in the circulating water are concentrated by evaporation and must be limited by bleed-off of some of the water. Chemical treatment is not normally required if adequate bleed-off is maintained.

Algae and slime may occur and can be controlled by careful application of proper chemicals. Improper application of concentrated water treating chemicals may damage parts of the system. If scale or algae and slime accumulate, obtain the services of a competent water treating consultant.

\section{WATER DISCOLORATION}

Discoloration of water may occur when a cooling tower is placed in operation. This discoloration is not harmful and will normally disappear after several weeks of operation. Application of a common bleach solution or increased bleed-off will alleviate this condition.

\section{FOAMING}

Foaming may occur when the concentration of dissolved solids in the circulating water is high. Increasing the bleedoff rate or application of commercial foam depressants will alleviate the problem. Foam depressants slightly alter the physical properties of the circulating water and may affect the tower operating characteristics. Dosages should not exceed manufacturer's recommended amounts. Trial of several brands may be necessary to achieve optimum foam control and tower operation.

\section{SEASONAL SHUTDOWN INSTRUCTIONS}

\section{BASIN AND FRAME}

Drain the tower basins and all exposed piping. Leave the basin drain open. Water may be left in cold water basin if tower is located in a non-freezing area.<smiles>[3H]</smiles>

During shutdown, clean the tower and make any necessary repairs. Apply protective coating as required to all metal parts. Particular attention should be given to bearing supports.

\section{MECHANICAL EQUIPMENT}

\section{V-BELTS AND SHEAVES}

1. At shutdown, remove and store belts in a $\infty o l$, dark, dry room. Clean and coat sheave grooves with rust pre- ventive, lacquer, or paint.

2. Before putting belts back on sheaves, remove rust preventive. Replace belts with excessive wear.

3. When putting tower back into service refer to "Mechanical Equipment Installation" page 4 for belt installation and tensioning instructions.

BEARING HOUSING, Oil Lubricated Type

1. At shutdown, operate until oil is warm; drain and refill. Use SAE 20 mineral oil.

2. Each month, drain water condensate at the drain plug. Check oil level and add oil if necessary.

3. At start-up, operate until oil is warm; drain and refill.

\section{ELECTRIC MOTORS}

Do not start motor without determining that fan is free to rotate.

Refer to motor manufacturer's recommendations for lubrication and maintenance instructions.

If shutdown period is longer than seasonal, contact The Marley sales office or representative in your area for additional information. Always refer to tower serial number when writing for information or ordering parts. The serial number is stamped on the tower name plate.

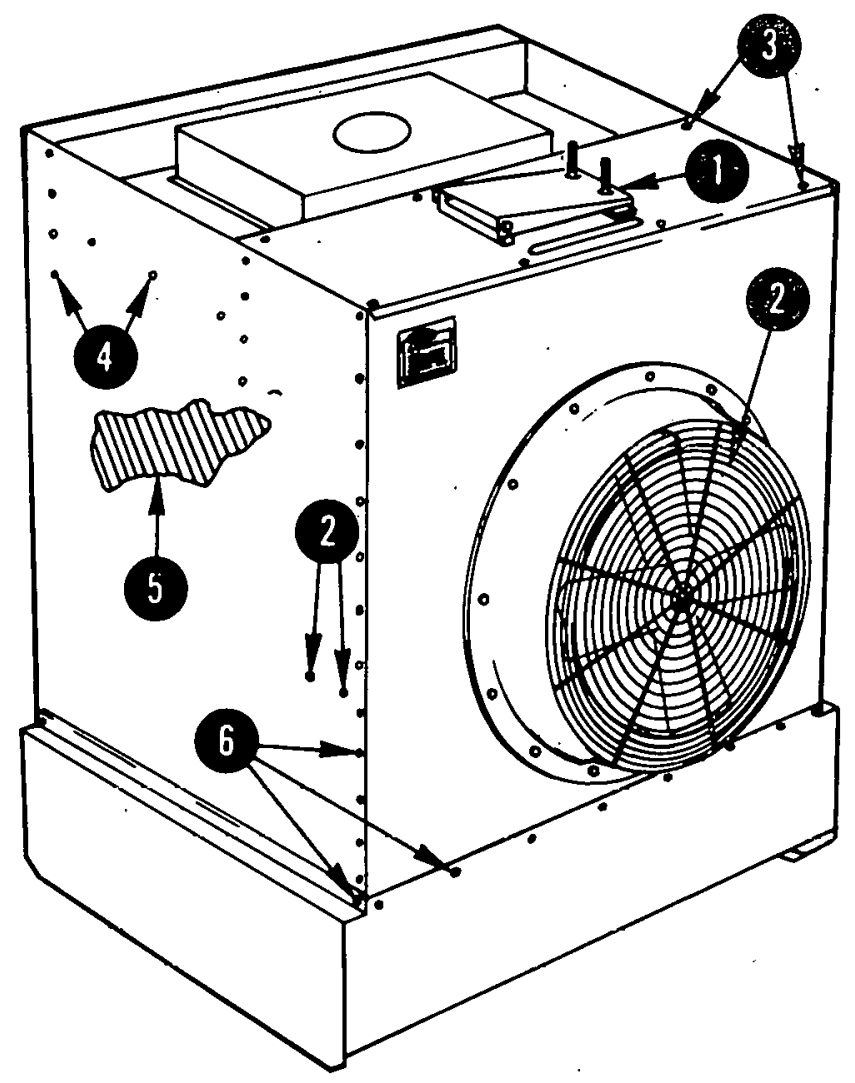




\section{DISASSEMBLY AND REASSEMBLY INSTRUCTIONS}

Never disassemble the Aquatower more than necessary; for example, if removal of the motor base is sufficient to get the tower to the installation site, remove only that part. When disassembling, remember how each part is screwed, bolted and set in place; fasten screws and bolts for each part with each section. Be careful not to mar galvanized coating.

DISASSEMBLY - 4619 thru' 4633 (sequence is similar for 4613 thru 4617 )

1. Remove motor base.

2. Remove fan guard, fan and all hardware attaching bearing housing support channel to casing sheets.

3. Remove screws attaching top sheet, then remove sheet:

4. Remove screws attaching distribution basin then remove basin.
5. Remove fill.

6. Remove screws from collection basin and side casing sheets at fan sheet. Remove side casing sheets and fan sheet with fan cylinder attached.

\section{REASSEMBLY}

Reassembly of the Aquatower is the reverse of the steps noted above.

The following precautions are important:

1. Fill must be installed level to assure full tower performance.

2. Bolts which use rubber sealing washers under head should be tightened securely to prevent leaks.

3. Be sure mechanical equipment is-installed correctly and fan rotatcs frecly.

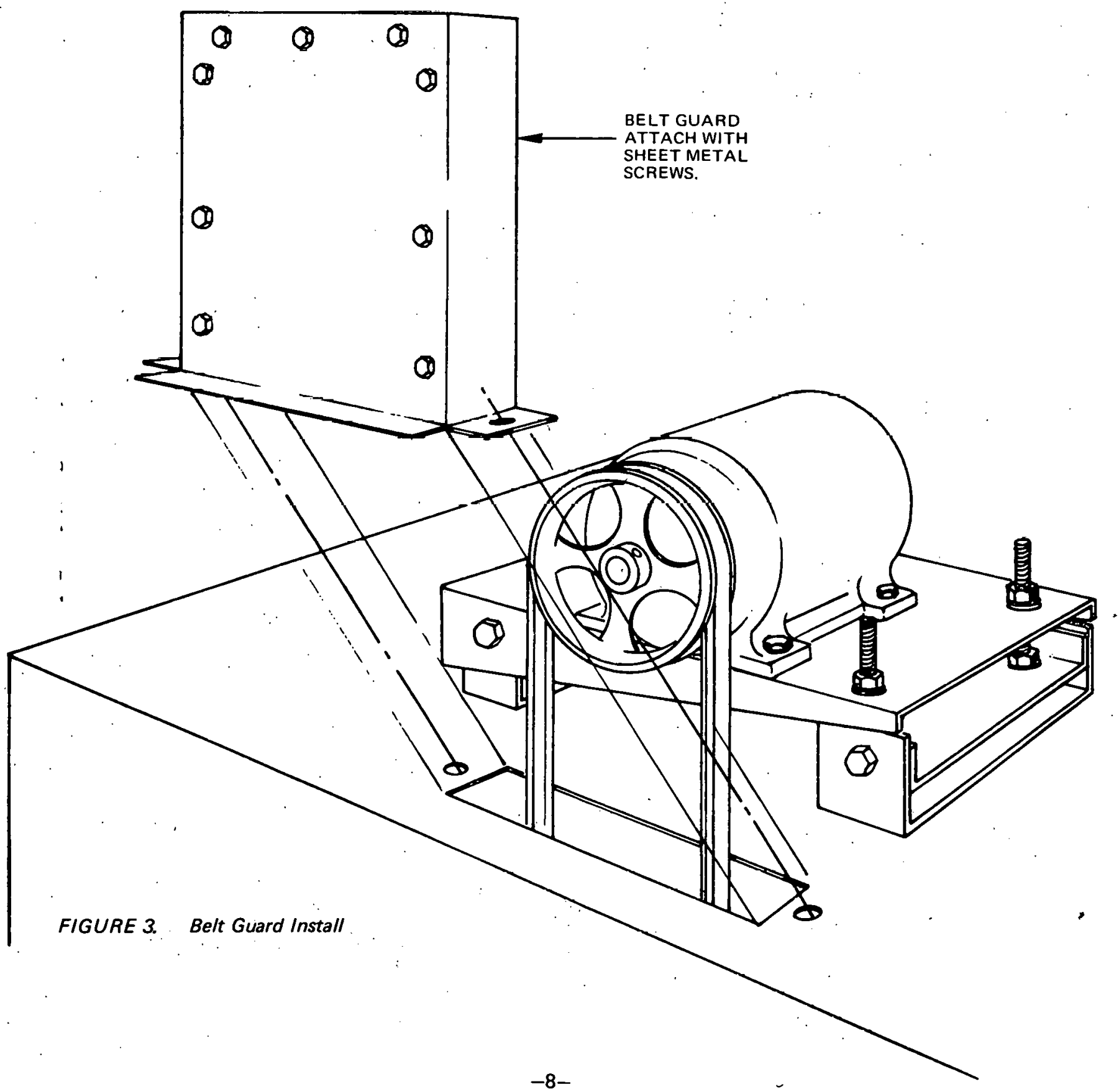


APPENDIX G

STORAGE TANK GAUGE CHART 


\section{GENERAL STEEL TANK CO. \\ 1000 EIGHTH AVENUE, NORTH \\ BIRMINGHAM, ALABAMA}

\section{GAUGE CHART}

FOR

TANK 96" DIA. X $13^{\prime} \div 5 \frac{1}{2} "$ LONG

LEVEL GALLONS

$1 *$

9

LEVEL

GALLONS

LEVEL

GALLONS

LEVEI

GALLONS

$1 " 1$

25"

1048

$49^{\prime \prime}$

2597

73".

4128

2

$26^{\prime \prime}$

1107

$50^{\prime \prime}$

2664

$74^{\prime \prime}$

4185

$3^{\prime \prime}$

47

27"

1167

$51 "$

2731

$75^{\prime \prime}$

4241

$4 "$

72

28"

1228

$52^{\prime \prime}$

2798

$76^{\prime \prime}$

4296

5

101

29"

1289

53 "

2865

$77^{\prime \prime}$

4350

$6 "$

132

30 "

1351

$54^{\prime \prime}$

2931

$78^{\prime \prime}$

4403

$7^{\prime \prime}$

165

31 '"

1414

55"

2998

$79 "$

4455

$8^{\prime \prime} \quad 201$

$32^{\prime \prime}$

1477

$56^{\prime \prime}$

3064

$80 "$

4506

$9^{\prime \prime} \quad 240$

$33^{\prime \prime}$

1540

$57^{\prime \prime}$

3130

$81 "$

4555

$30 "$

280

$34^{\prime \prime}$

1604

58"

3196

82"

4603

111.322

$35^{\prime \prime}$

1669

$59^{\prime \prime}$

3262

83"

4650

12

365

.36"

1733

$60 "$

3327

$84^{\prime \prime}$

4695.

$13^{\prime \prime}$

410

$37 !$

1798

$61 "$

3391

$85^{\prime \prime}$

4738

$14^{\prime}$

457

1864

$62^{\prime \prime}$

3456

86 "

4780

$15^{\prime \prime}$

505

$39 "$

19.30

$63^{\circ \prime}$

3520

$87^{\circ}$

$64^{\prime \prime}$

3583

88"

4820

554

$40 ! 1$

1996

$41^{\prime \prime}$

2062

$65^{\prime \prime}$

3646

89"

4859

17

605

$42^{\prime}$

2129

66"

3709

$90^{\prime \prime}$

2195

$67^{\prime}$

3771

91"

2262

68 "

3832

92"

3893

93"

3953

94"

4895

2329

$69^{\circ}$

2396

$70^{\circ}$

2463

71 "

4012

$95^{\prime \prime}$

$.107]$

$96 "$

4928

$4 ? 59$

7988

5013

5034

$48^{\circ}$

2530

$72^{\circ}$

5051 5060 
APPENDIX $\mathrm{H}$

SOLENOID VALVE

$\mathrm{H}-\mathbf{i}$ 


\section{SOLENOID VALVE COIL DATA}

$\mathrm{H}-1$

COILS

2.5.

Form No. V - 5192 ARA

\begin{tabular}{|c|c|c|c|}
\hline \multicolumn{4}{|c|}{ COIL CLASSIFICATION } \\
\hline Cosk IrFt & $\begin{array}{l}\text { GRADE OF } \\
\text { IISULATION }\end{array}$ & $\begin{array}{l}\text { AEDBIENT } \\
\text { TEMP. (NOTE 1) } \\
\end{array}$ & APPLICATION CONDITIONS (MOTE 2) \\
\hline Class A & A & $77^{\circ} \mathrm{F}$ & \begin{tabular}{|l}
$\begin{array}{l}\text { For normal pressure or ambient temperatures } \\
\text { (For molded coils see Note } 3)\end{array}$ \\
\end{tabular} \\
\hline $\begin{array}{l}\text { Cisss F (FT) } \\
\text { High Temp. }\end{array}$ & F & $167^{\circ} \mathrm{F}$ & $\begin{array}{l}\text { For high ambient of fluid temperatures (Notes } \\
3 \& 5 \text { ) }\end{array}$ \\
\hline $\begin{array}{l}\text { Class F(FB) } \\
\text { Intermediate } \\
\text { Power }\end{array}$ & $\mathbf{F}$ & $122^{\circ} \mathrm{F}$ & $\begin{array}{l}\text { For higher valve pressure ratings, high ambient } \\
\text { or fluid temperatures (Mote 3) }\end{array}$ \\
\hline $\begin{array}{l}\text { Class F (FF) } \\
\text { High Powar }\end{array}$ & $\mathbf{F}$ & $77^{\circ} \mathrm{F}$ & $\begin{array}{l}\text { For higher valve pressure ratings at normal } \\
\text { ambient temperatures (Mote } 3 \text { ) }\end{array}$ \\
\hline $\begin{array}{l}\text { Class } \mathrm{H}(\mathrm{HT}) \\
\text { High } T \in \mathrm{H}^{\prime} \text {. }\end{array}$ & H & $212^{\circ} \mathrm{F}$ & $\begin{array}{l}\text { For Higher ambient or fluid temperatures than } \\
\text { Class F (Notes 4 \& 5) }\end{array}$ \\
\hline $\begin{array}{l}\text { Class H(HB) } \\
\text { lntermadiate } \\
\text { Power }\end{array}$ & H & $167^{\circ} \mathrm{F}$ & $\begin{array}{l}\text { For higher valve pressure ratings, plus higher } \\
\text { ambient or fluid temperatures than Class F } \\
\text { (Note 4) }\end{array}$ \\
\hline $\begin{array}{l}\text { Class H(HP) } \\
\text { High Power }\end{array}$ & H & $77^{\circ} \mathrm{F}$ & $\begin{array}{l}\text { For higher valve pressure ratings than Class } \mathrm{F} \text {, } \\
\text { at normal ambient temperatures (Note 4) }\end{array}$ \\
\hline \multicolumn{4}{|c|}{$\begin{array}{l}\text { WOTES: 1. This is the maximum ambient temperature for continuous duty. Coils rated for ambient } \\
\text { temperatures of } 77^{\circ} \mathrm{F} \text { may be employed in areas where ambient temperatures reach } \\
104^{\circ} \mathrm{F} \text { occasionally. } \\
\text { 2. The maximum fluid temperature will vary between solenoids and valve types, refer to } \\
\text { catalog listings for maximum temperature limitations. } \\
\text { 3. Molded coils are moisture proof and fungus proof. } \\
\text { 6oils are fungus proof and radiation resistant. } \\
\text { 6. Suitable for } 24,120,240,480 \text { volts, } \mathrm{A}-\mathrm{C} 60 \mathrm{HZ} \text { (or } 50 \mathrm{HZ} \text { in } 110 \text { volt multiples) }\end{array}$} \\
\hline
\end{tabular}

Fig. 1

\section{ACCESSORIES}

Plense and information on the folluwing:

$\square$ STRAINERS

[] SPEED CONTROL VALVES

Maintenance Instructions for ASCO valves will be gladly furnished. To request copies, specify the valve catalog number.
STRAINERS

Remove dirt and pipe scale from the line to reduce friction and provide longer life for equipment.

\begin{tabular}{|c|c|c|c|c|}
\hline \multicolumn{5}{|c|}{ CONTINUOUS DUTY RATING } \\
\hline $\begin{array}{c}\text { VOLTAGE } \\
\text { RATING } \\
\text { A-C }\end{array}$ & $\begin{array}{c}\text { NORMAL } \\
\text { OPERATING } \\
\text { RANGE }\end{array}$ & $\begin{array}{c}\text { VOLTAGE } \\
\text { RATING } \\
\text { D-C }\end{array}$ & $\begin{array}{c}\text { NORERAL } \\
\text { OPERATIMG } \\
\text { RANGE }\end{array}$ \\
\hline 24 & $22-24$ & 6 & $5.1 \cdot 6.3$ \\
120 & $110-120$ & 12 & 10.2 & 126 \\
240 & $220-240$ & 24 & 20 & 26 \\
480 & $440-480$ & 120 & 102 & 126 \\
\hline $\begin{array}{l}\text { All ASCO valves are tested to operate at 15\% under tha nominal } \\
\text { voltage and are capable of operating for short periods at 10\% over } \\
\text { the nominal voltage. For wider voltage ranges than shown above, a } \\
\text { different coil must be used. }\end{array}$ \\
\hline
\end{tabular}

Fig. 3

\section{INSTRUCTIONS FOR REPLACING COIL}

Turn off electric power supply and line pressure to the valve. Discon. nect the coil lead wires. Remove the solenoid cover. Disassembie and reassemble in order shown in Fig. 2.

NOTE: The solenoid must be fully reassembled as the housing is part of and completes the magnetic circuit.

NOTE: To change from Alternating Current $(\mathrm{A}-\mathrm{C})$ to direct Current $(\mathrm{D}-\mathrm{C})$ or reverse, it is necessary to change the complete solenoid.

\section{Fig. 4}

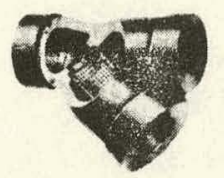

SPEED CONTROL VALVES

For controlling cylinder piston speeds. Used with ASCO 3 and 4 way solenoid valves.

\section{EXPLODED VIEWS}
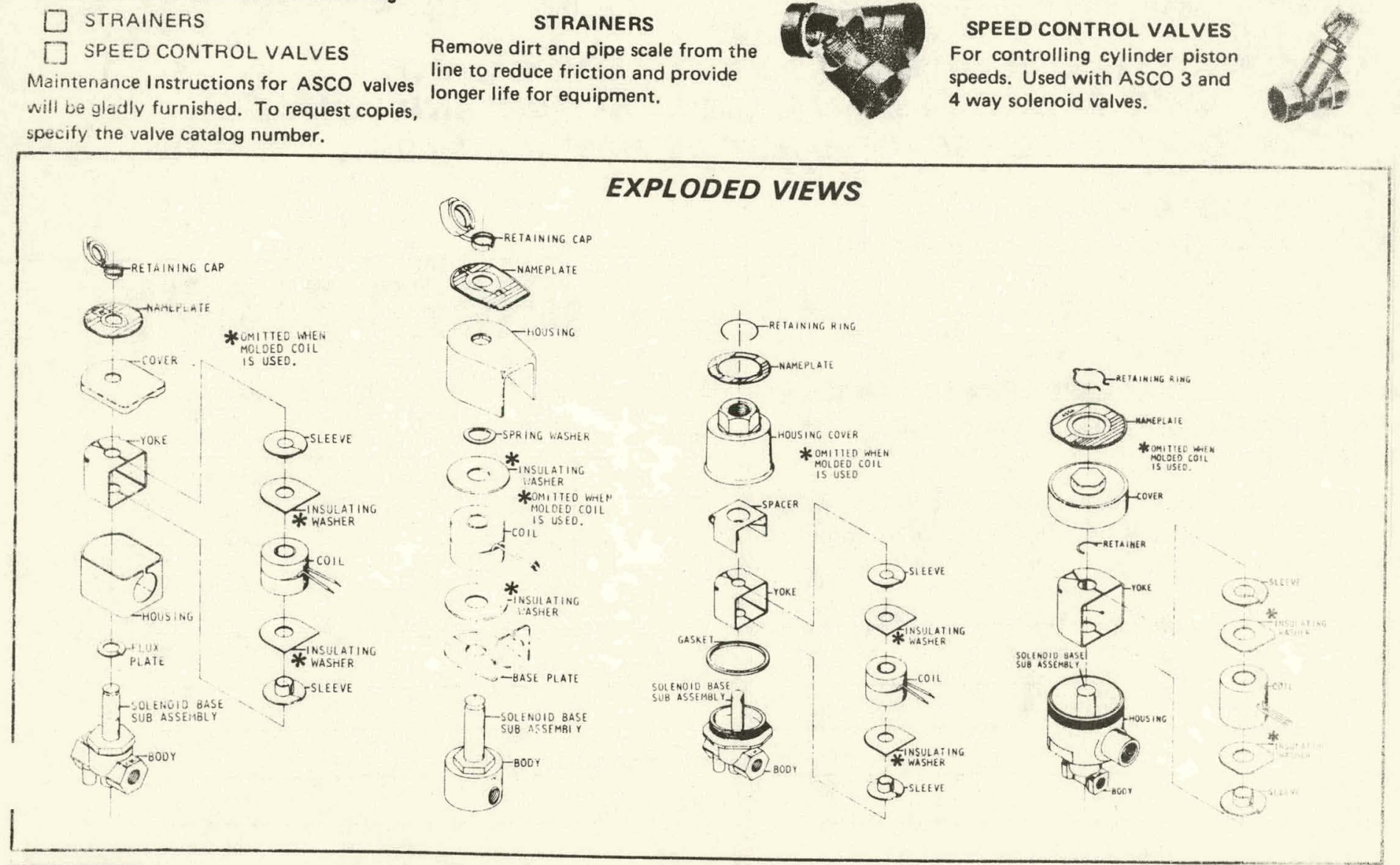


\section{SPARE PARTS KITS $\mathrm{H}-2$ \\ REPLACEMENT COILS AND ACCESSORIES FOR ASCO SOLENOID VALVES}

KITS AND COILS

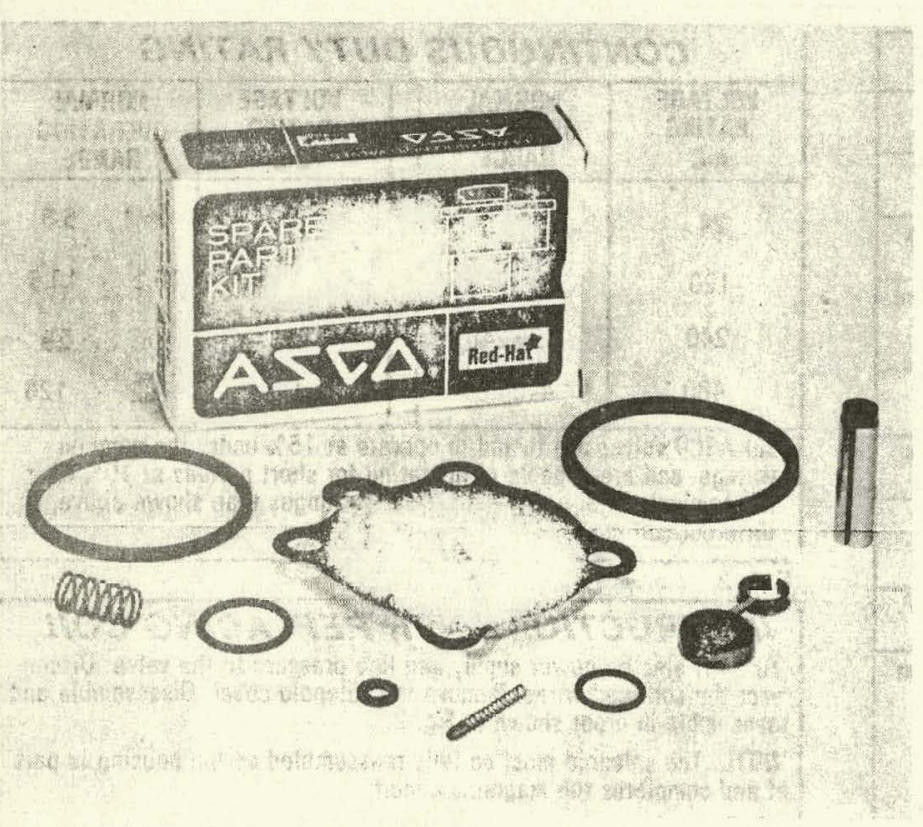

SPARE PARTS KITS

Kits contain all necessary internal operating parts with gaskets, "O" rings, etc.
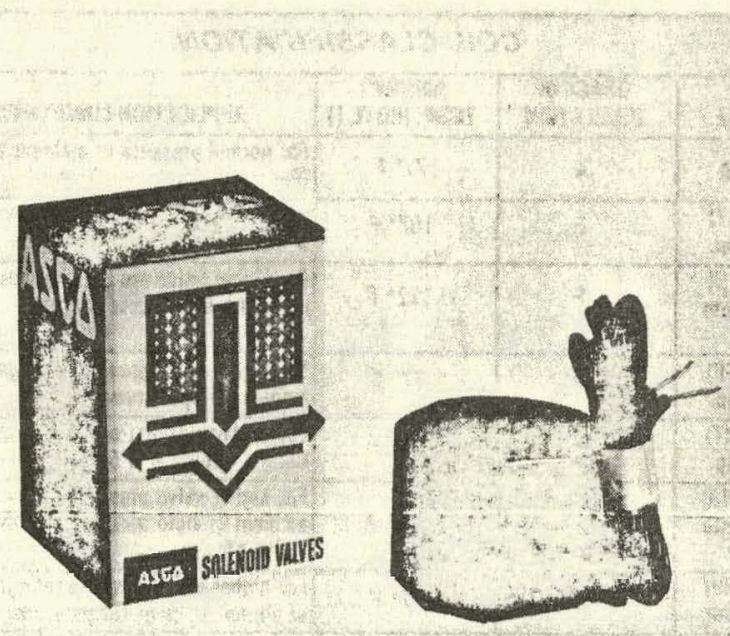

REPLACEMENT COILS

Coil types available are listed under coil classification Figure 1 (over)

FOR KIT OR COIL NUMBER REFER TO VALVE CATALOG OR SUPPLY VALVE CATALOG NUMBER, SERIAL NUMBER AND VOLTAGE FOR CONVENIENCE, USE THE HANDY ORDER BLANK BELOW

\section{ASCA. ASCO Valves}

Automalic Suftch Co. florham park, new Jersey

TO:AUTOMATIC SWITCH CO.

DISTRICT OFFICE, SALES REPRESENTATIVE OR ASCO AUTHORIZED STOCKING DISTRIBUTOR

For the address of the office nearest you, refer to the white pages of your telephone directory under ASCO or Automatic Switch Co.

AUTOMATIC SWITCH CO. Florham Park, N. J. 07932

NAME

\section{STREET ADDRESS}

CITY

STATE

SHIP VIA

SIGNED

\section{ORDER BLANK}

DATE:

ORDER NUMBER

PLEASE SEND THE FOLLOWING:

\begin{tabular}{l|l|l}
\hline QUANTITY & SPARE PARTS KIT & REPLACEMENT COIL \\
\hline & & \\
\hline & & \\
\hline & & \\
\hline
\end{tabular}

A C CESSORIES

VALVE CATALOG NO.

SERIAL NO.

VOLTAGE 
$\mathrm{H}-3$

Pages $\mathrm{H}-3$ through $\mathrm{H}-6$ have been deleted because of 1977 copyright restrictions. For information on solenoid valves, bulletins 8201 and 8211 , contact Automatic Switch Company, Florham Park, New Jersey 07932. 
APPENDIX I

FLORATER BALANCING VALVE CHART

I-i 


\section{Features}

1. Gauge Connections with integral check valves and threaded protectors

2. Valve position indicator with scale

3. Heat resistant packing

4. Butterfly balancing valve

5. Solder connections for ease of installation (threaded connections also available)

6. Sturdy bronze bedy (Iron body also available)

7. Precision machined orifice

\section{How to Size the Florater}

The FInrater is sized to the GPM required for the design loop. (Example) 7 GPM is required for a system loop. Locate 7 GPM on the horizontal scale of the chart. Trace 7 GPM up the vertical scale and find that 7 GPM will intersect with $1-1 / 4$ " Florater and 1" Florater.

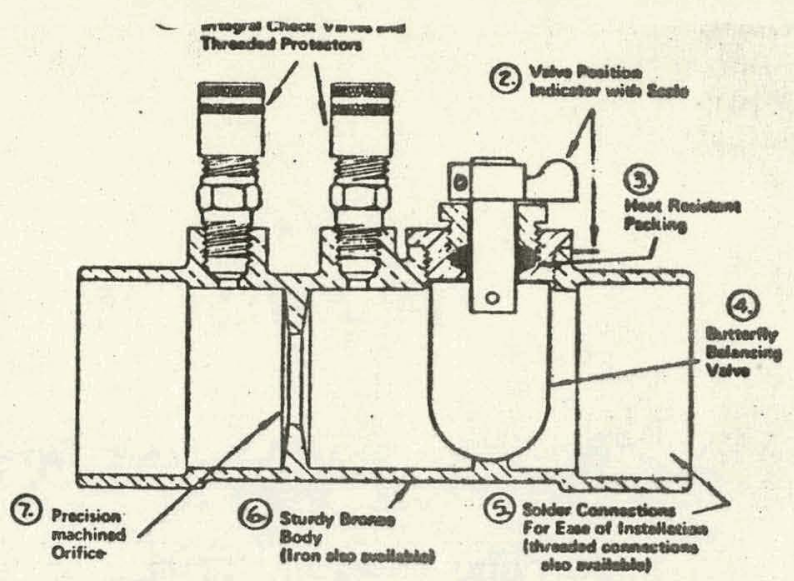

How to Adjust the Florater

To set the Florater for the proper GPM required. use a differential pressure gauge. Assume a $1^{\prime \prime}$ value is to be used as in the example at left. A 1 " valve at 7 GPM requires a meter reading of 27 " of water indicated on left vertical scale. Adjust the Florater Balancing valve until $27^{\circ}$ of water differential pressure is indicated on the gauge. Record or mark the Florater scale setting for easy reference or readjustment.

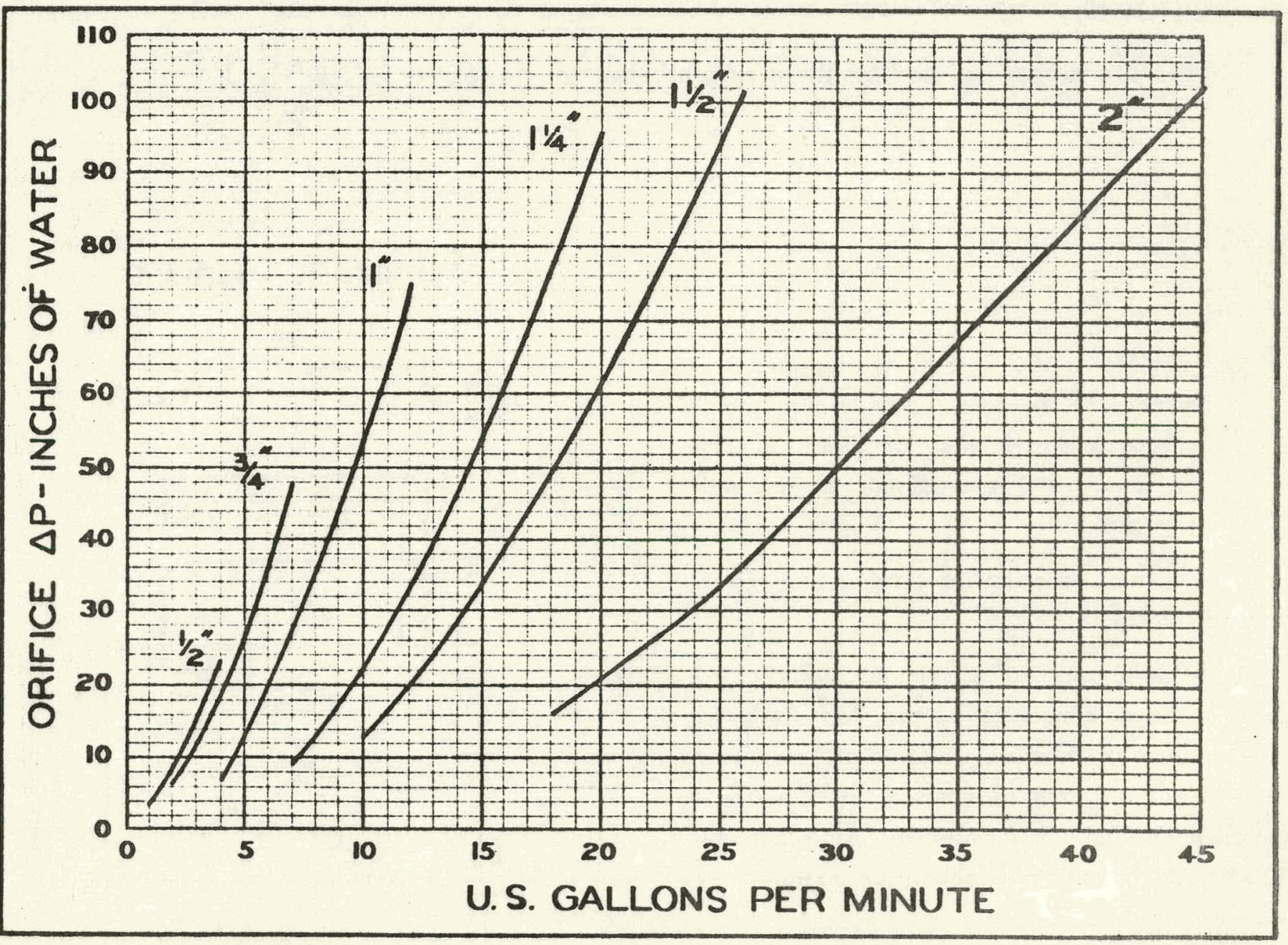




\section{MID-WEST MODEL 832 FLOW TEST KIT}

\section{Basic Operating Instructions}

1. Open carrying case and sit in a convenient spot on test site with test kit horizontal.

2. With balance valve closed, connect hoses to meter - Red hose upstream, High Pressure - Green hose downstream - Low. Pressure.

3. Open balance valve (bottom of panel).

4. Open high and low bleed valves alternately to purge air from system. (Bleed water discharges from convenient clear plastic flexible tube.)

5. When bleeding shows all air removed-close Balance Valve and read Differential Pressure Gauge. Refer to chart for conversion to GPM.

6. When test is complete - open balance valve before disconnecting Test Hoses from meter.

7. Hoses are stored by coiling them around the test panel.

\section{Schematic Diagram}

NOTE: The Model 832 Test Kit is equipped with screens in the inlet hoses. If the gauge responds slowly when the balance valve is closed; the screens may. be partially plugged.

To flush out and clean the screens and restore normal operation:

Open the Balance Valve. With the high and low pressure hoses connected to the flow meter (or other source of pressure), alternately disconnect the high, and then the low pressure hoses, and flush out each hose until the flow is clear. Approximately 30 seconds for each hose should be adequate.

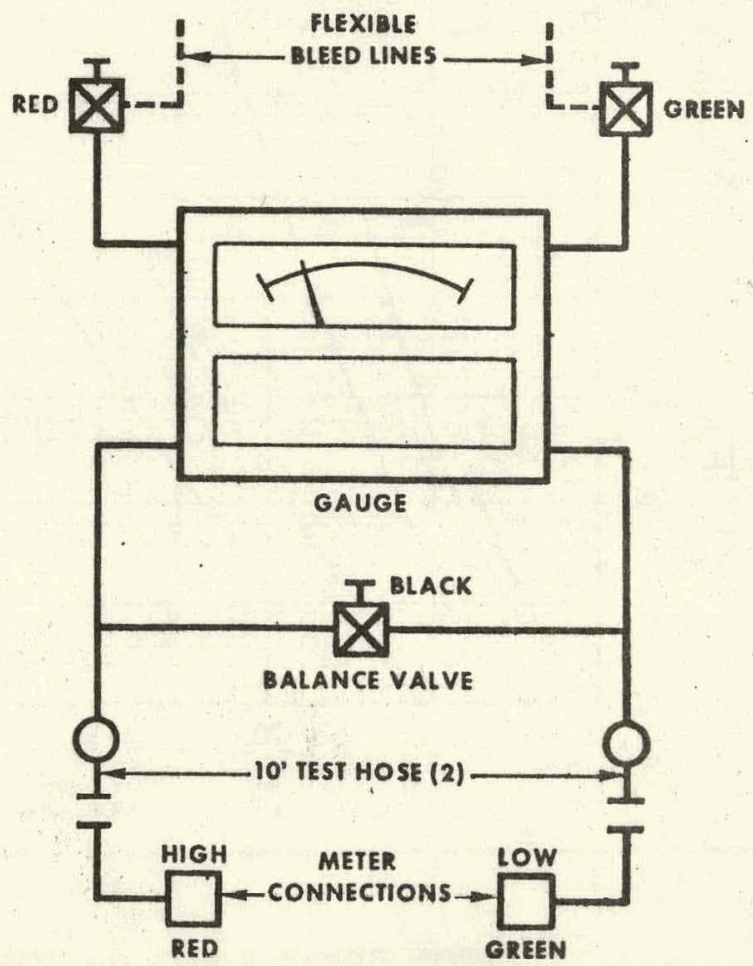


APPENDIX J

AIR RELEASE VALVE

J-i 


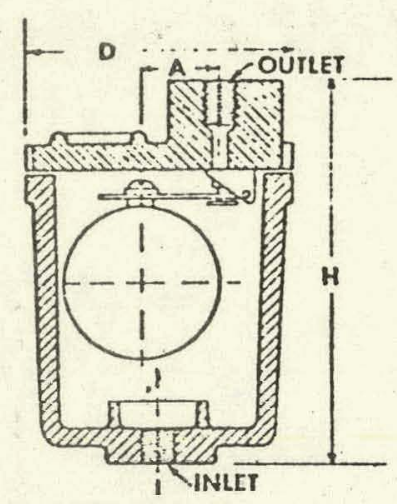

No. 69

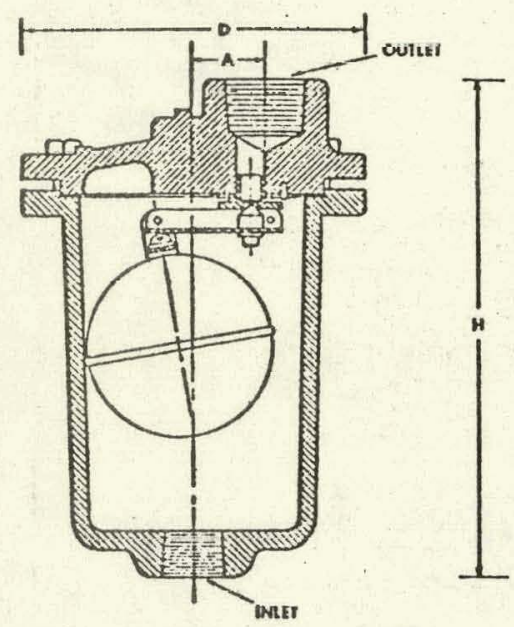

Nos. $70 A, 72 A, 73 A$, and 74

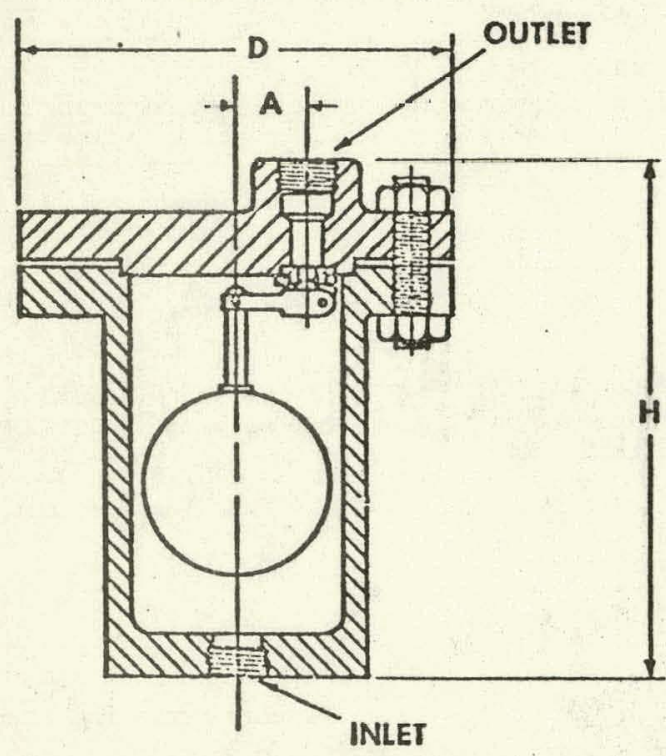

Nos. 213, 214, and 216

\section{MATERIALS}

Rugged Cast Metal housing, stainless steel or non-corrosive internal.

\begin{tabular}{|c|c|c|c|c|c|c|c|c|}
\hline \multicolumn{9}{|c|}{ SPECIFICATIONS } \\
\hline Size Number of Valve & 69 & $770 A$ & $72 \mathrm{~A}$ & $73 A$ & 74 & 213 & 214 & 216 \\
\hline $\begin{array}{l}\text { Size Pipe Connections } \\
\quad \text { (inlet) } \\
\text { Size Pipe Connections } \\
\text { (outlet) } \\
\text { Shipping Weight, Ibs. } \\
\text { Maximum Pressure PSI } \\
\end{array}$ & $\begin{array}{c}1 / 2 " \\
3 "^{\prime \prime} \\
4 \\
100\end{array}$ & $\begin{array}{c}1 / 2 " \text { or } \\
3 / 4 " \\
1 / 2 " \\
7 \\
150\end{array}$ & $\begin{array}{c}1 / 2 " \text { or } \\
3 / 4^{\prime \prime} \\
1 / 2 " \\
10 \\
250 \\
\end{array}$ & $\begin{array}{l}1 " \text { or } \\
11 / 4^{\prime \prime} \\
3 / 1 " \\
34 \\
250 \\
\end{array}$ & \begin{tabular}{c|}
$11 / 2 "$ or \\
$2 "$ \\
$1 "$ \\
58 \\
250 \\
\end{tabular} & $\begin{array}{l}1 / 2 " \text { or } \\
1 / 3^{n \prime} \\
1 / 20 \text { or } \\
2 / s^{n} \\
38 \\
600 \\
\end{array}$ & $\begin{array}{l}1 " \text { or } \\
11 / 4^{\prime \prime} \\
110 \text { or } \\
11 /{ }^{\prime \prime} \\
60 \\
600\end{array}$ & $\begin{array}{c}1 \frac{1}{2 "} \text { or } \\
2{ }^{\circ \prime} \\
11 / 2^{\prime \prime} \text { or } \\
2^{\circ \prime} \\
150 \\
1000\end{array}$ \\
\hline Operating Pressure & \multicolumn{8}{|c|}{ CAPACITY CU. FT. FREE AIR PER MINUTE } \\
\hline $\begin{array}{r}10 \\
20 \\
30 \\
50 \\
75 \\
100 \\
125 \\
150 \\
200 \\
250 \\
300 \\
400 \\
500 \\
600 \\
700 \\
1000 \\
\end{array}$ & \begin{tabular}{|c|}
5.2 \\
7.5 \\
$10.0^{*}$ \\
5.7 \\
7.8 \\
10.0
\end{tabular} & \begin{tabular}{|c|}
11.0 \\
15.5 \\
$20.0^{*}$ \\
9.2 \\
10.8 \\
12.2 \\
13.5 \\
$14.7^{*}$
\end{tabular} & $\begin{array}{l}21.0 \\
30.0 \\
39.5^{\circ} \\
15.0 \\
20.5 \\
25.0^{\circ} \\
30.0 \\
33.5^{\circ} \\
25.0 \\
28.0\end{array}$ & $\begin{array}{c}25.0 \\
40.0 \\
55.0 \\
75.0^{\circ} \\
80.0 \\
100.0^{\circ} \\
100.0 \\
125.0^{\circ} \\
85.0 \\
115.0\end{array}$ & $\begin{array}{l}136 \\
193 \\
252^{\circ} \\
130 \\
180^{\circ} \\
164^{\circ} \\
125 \\
147 \\
196^{\circ} \\
168 \\
.\end{array}$ & $\begin{array}{l}58.0 \\
37.0 \\
48.0 \\
55.0 \\
65.0 \\
50.0 \\
60.0 \\
55.0\end{array}$ & $\begin{array}{r}105.0 \\
85.0 \\
110.0 \\
65.0 \\
80.0 \\
90.0 \\
100.0 \\
70.0\end{array}$ & $\begin{array}{l}250.0 \\
320.0 \\
290.0 \\
210.0 \\
190.0 \\
190.0 \\
220.0 \\
180.0 \\
200.0 \\
200.0 \\
\end{array}$ \\
\hline \multicolumn{9}{|c|}{ DIMENSIONS } \\
\hline Trap Size & & & A & & D & & $H$ & \\
\hline $\begin{array}{r}69 \\
70 \\
72 \\
73 \\
74 \\
213 \\
214 \\
216\end{array}$ & & & 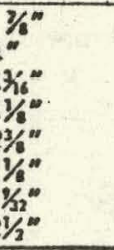 & - & 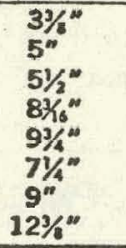 & & $\begin{array}{c}5 \% \\
6 \% \\
8 \% \\
8 \% \\
12^{\prime \prime} \\
14^{\prime \prime} \\
9 \% \\
11 \% " \\
11 \%\end{array}$ & \\
\hline
\end{tabular}

- Denotes capacity with larger orifice available at this pressure.

Noto: Pipe sizes shown in heavy type are standard and traps will bo shipped topped standard unless otherwise specified. Pipe sizes shown in light type furnished at no additional cost but only from Cleveland stock.

\section{INSTALLATIONS}

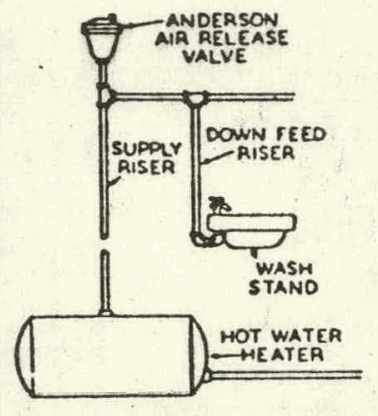

Venting air from hot water service lines in multi-story building.

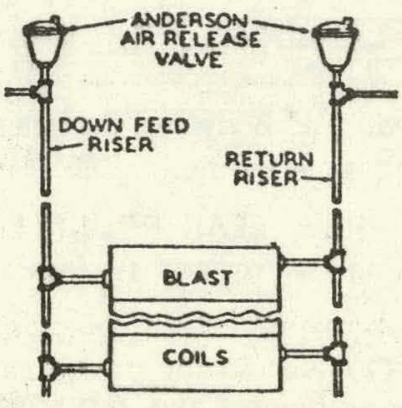

Venting air from hot water heating or chilled water cooling coils.

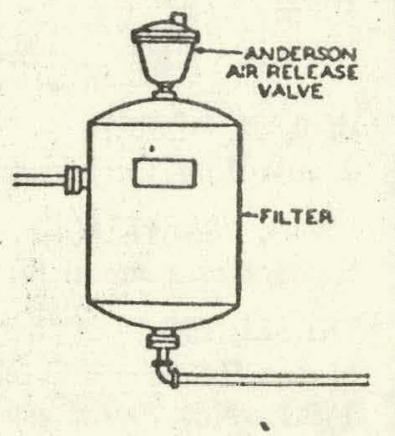

Venting air from filter tanks and other process equipment. 
APPENDIX K

LIST OF AS-BUILT DRAWINGS

$\mathrm{K}-\mathbf{i}$ 
LIST OF AS-BUILT DRAWINGS

Drawing No.

$45615881-B$

45615882-F

45615883-F

$45615884-F$

$45615885-C$

$45615888-D$

$45616107-R$

45616109-B

A2 45-D1-1-C

A2 45-D1-2-B

A2 45-P1-Z-D
Title

Mechanical Room Equipment Location

Piping Diagram for Potable water Heater and Heat Dump Circuits

Piping Schematic - Heating Loop

Piping Diagram from Tanks to Solar Panels

Piping Diagram - Solar Collector System

Location and Piping Diagram for Ground Mounted Collectors \& Returns

Electrical Schematic Diagram

Solar Storage Tank - Steel

Solar Collector Supports

Framing Details A through D

Typical Connection Details 


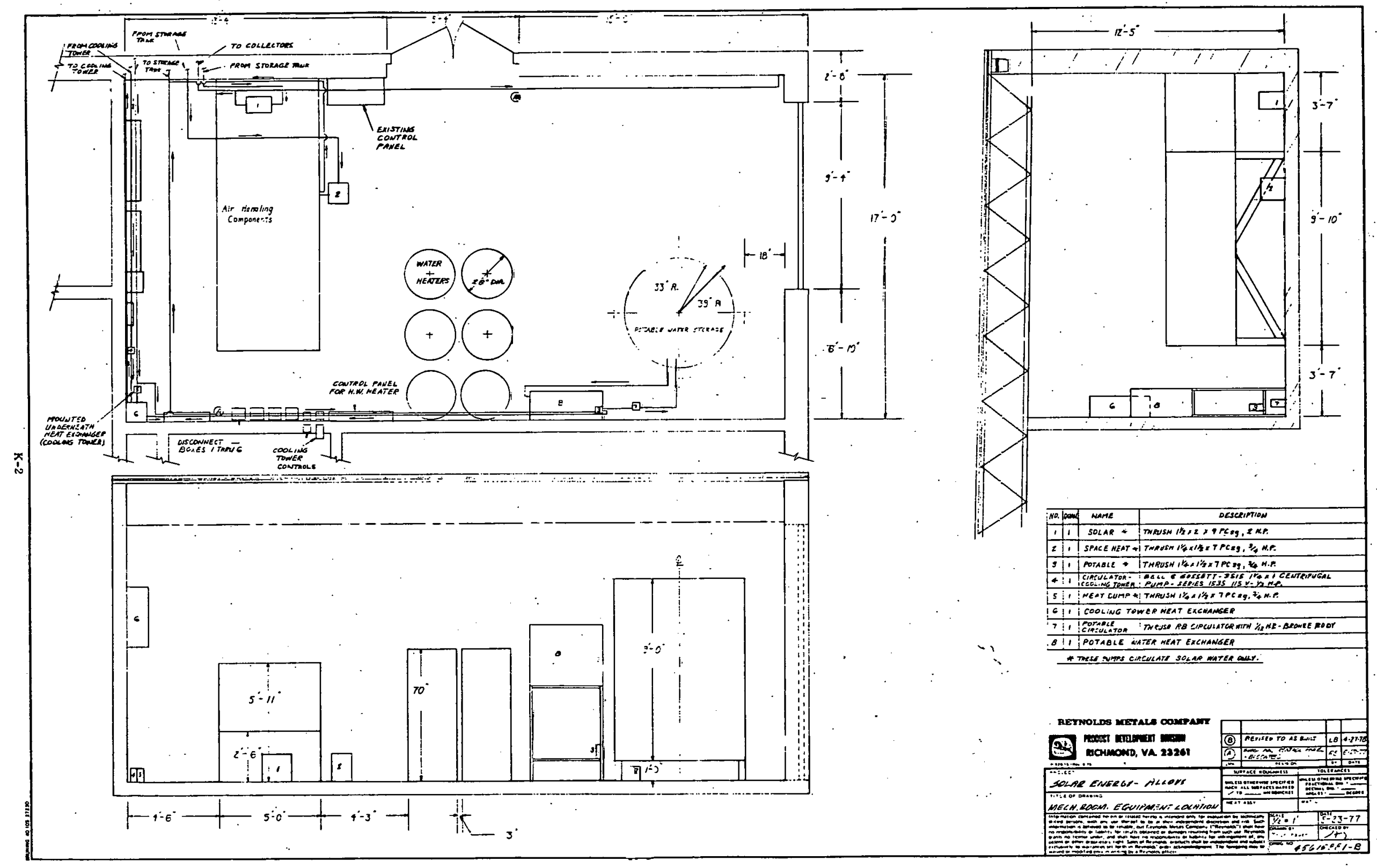




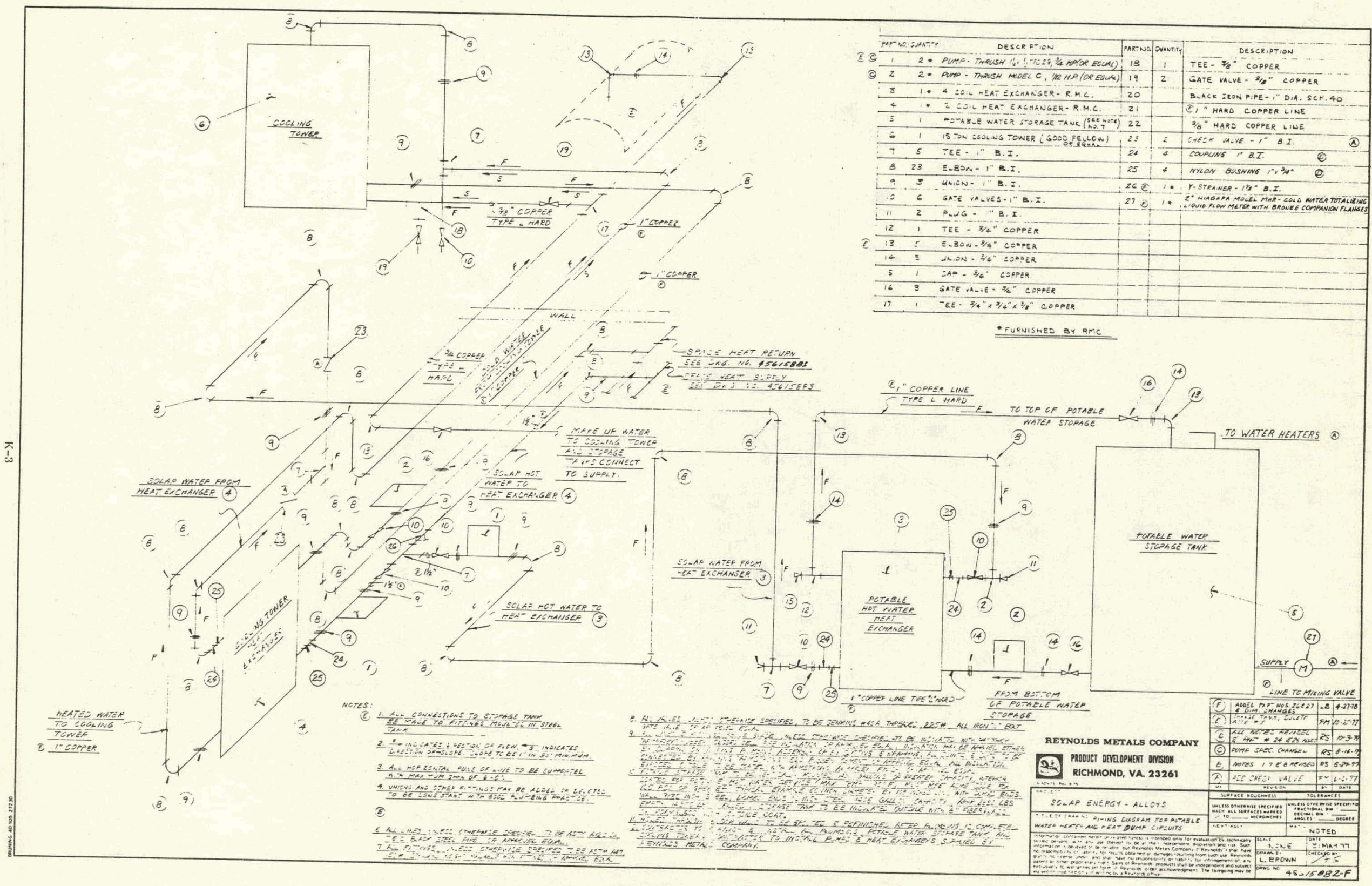




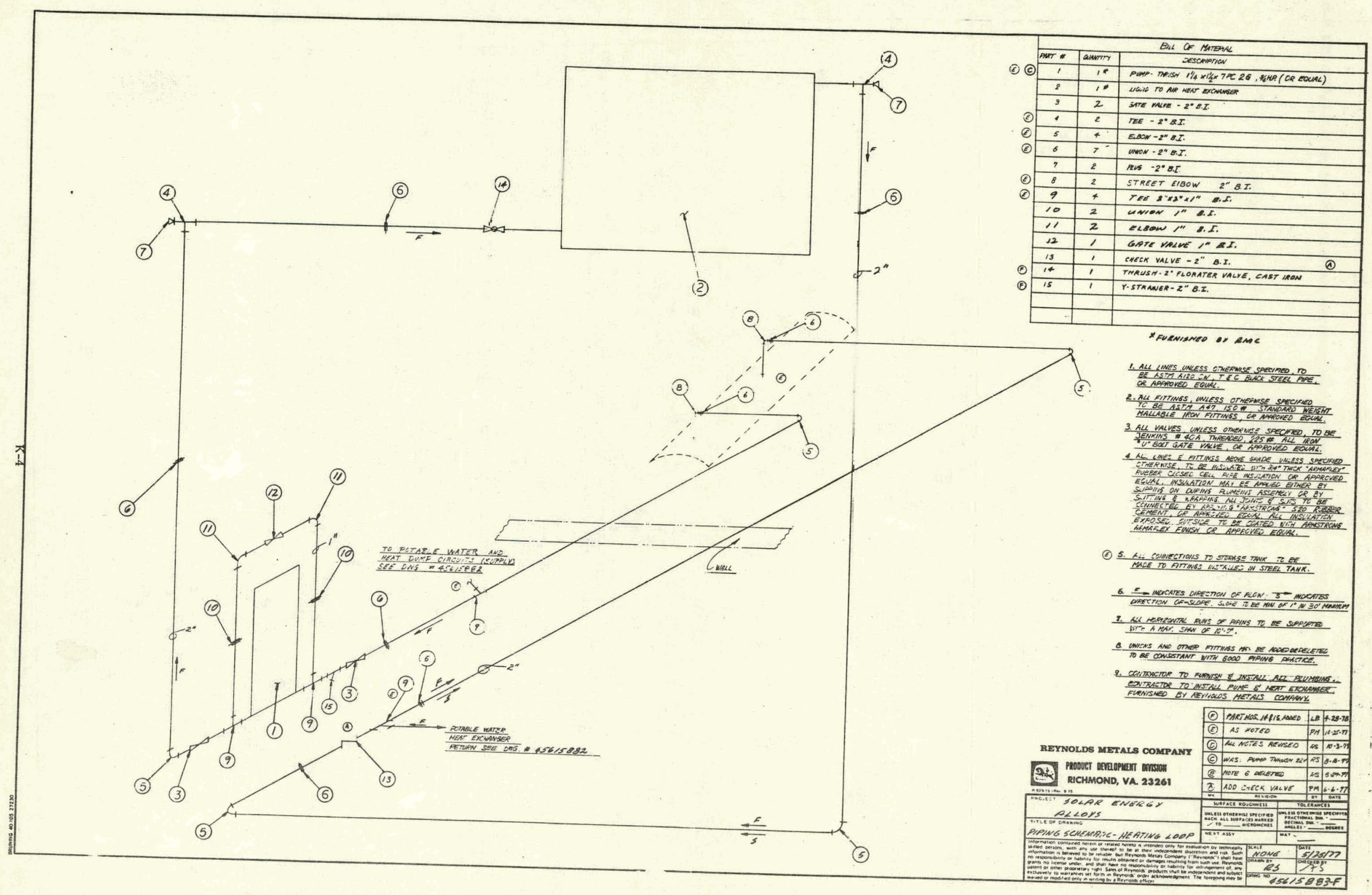




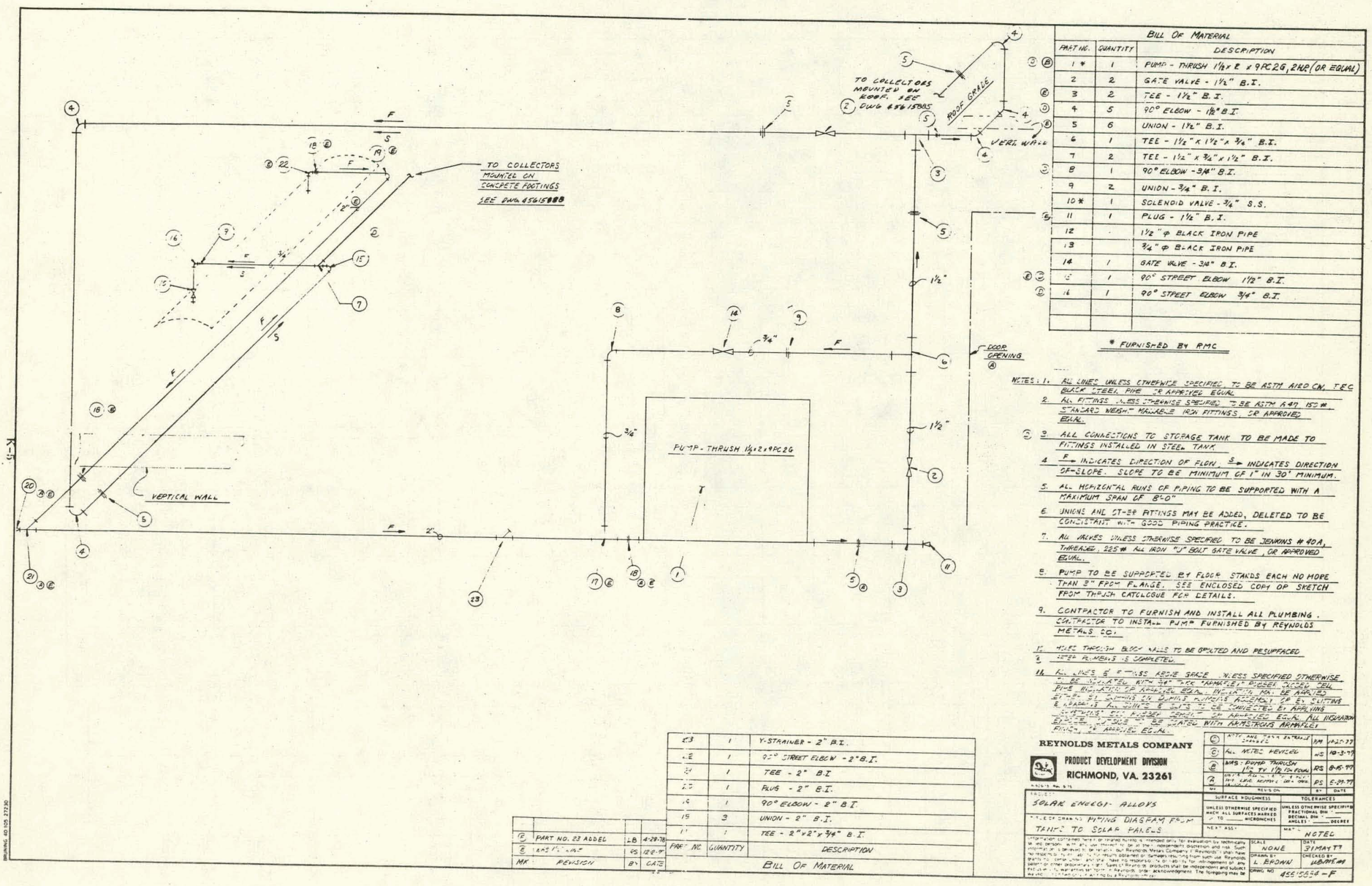




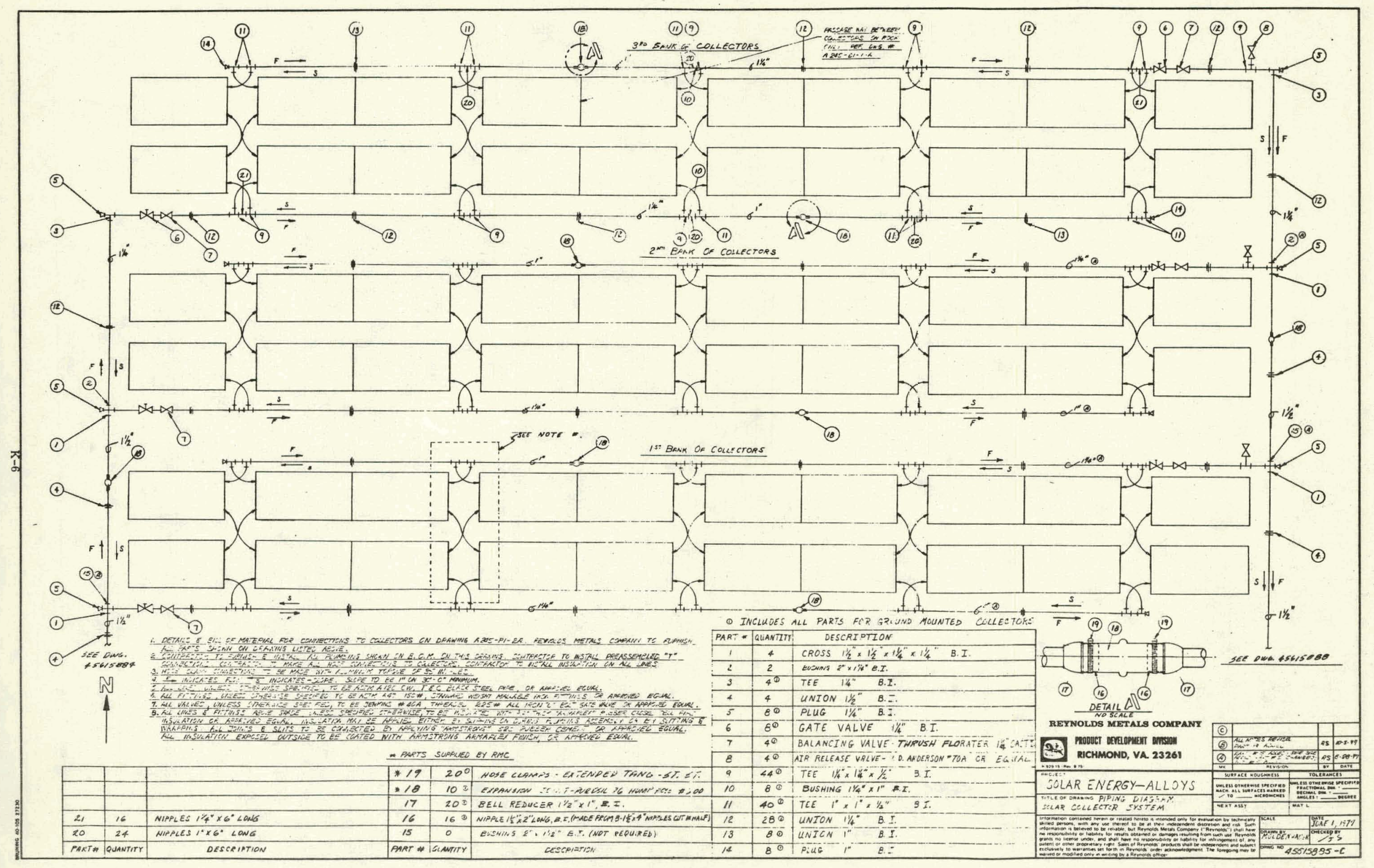




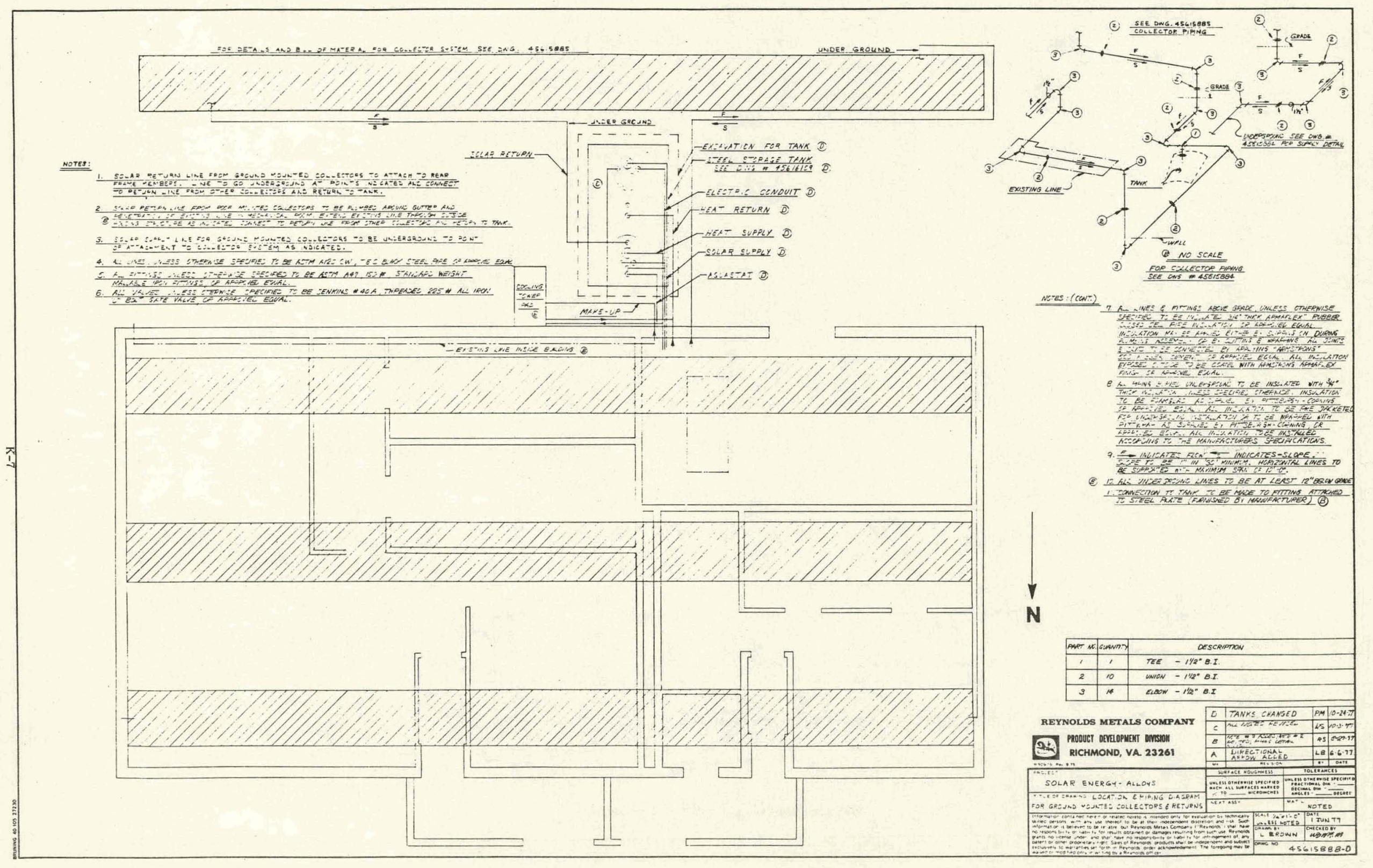




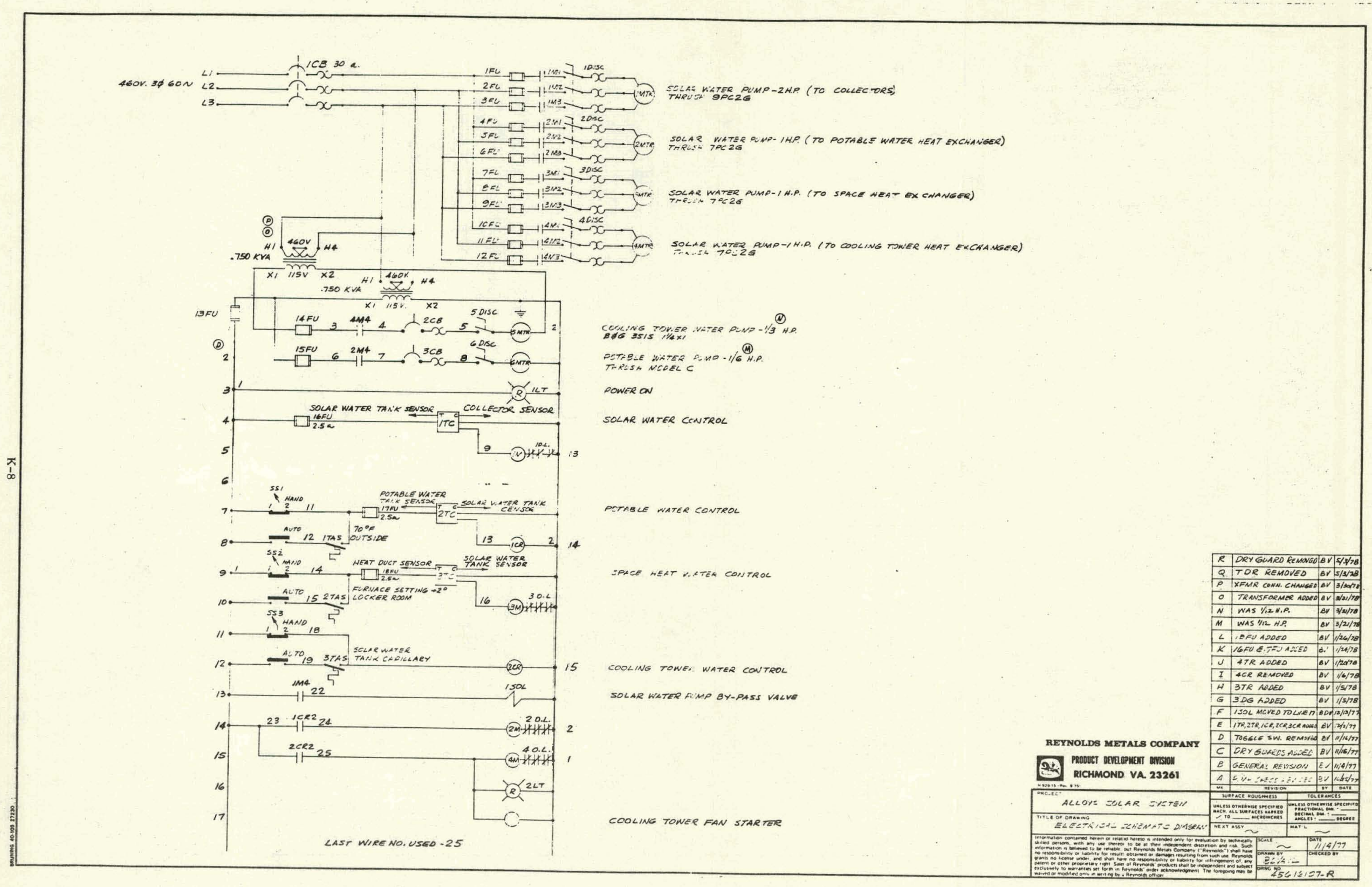



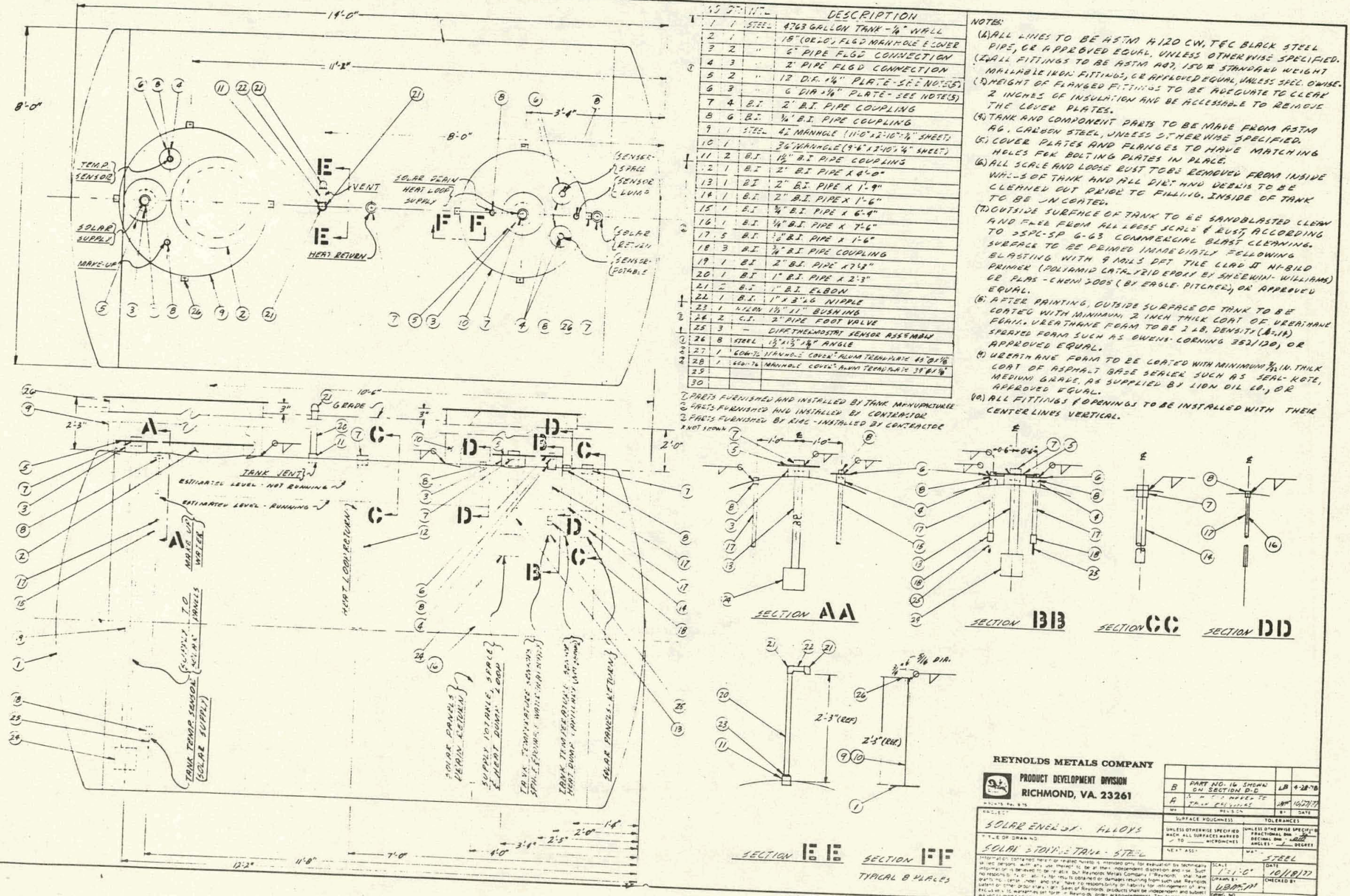


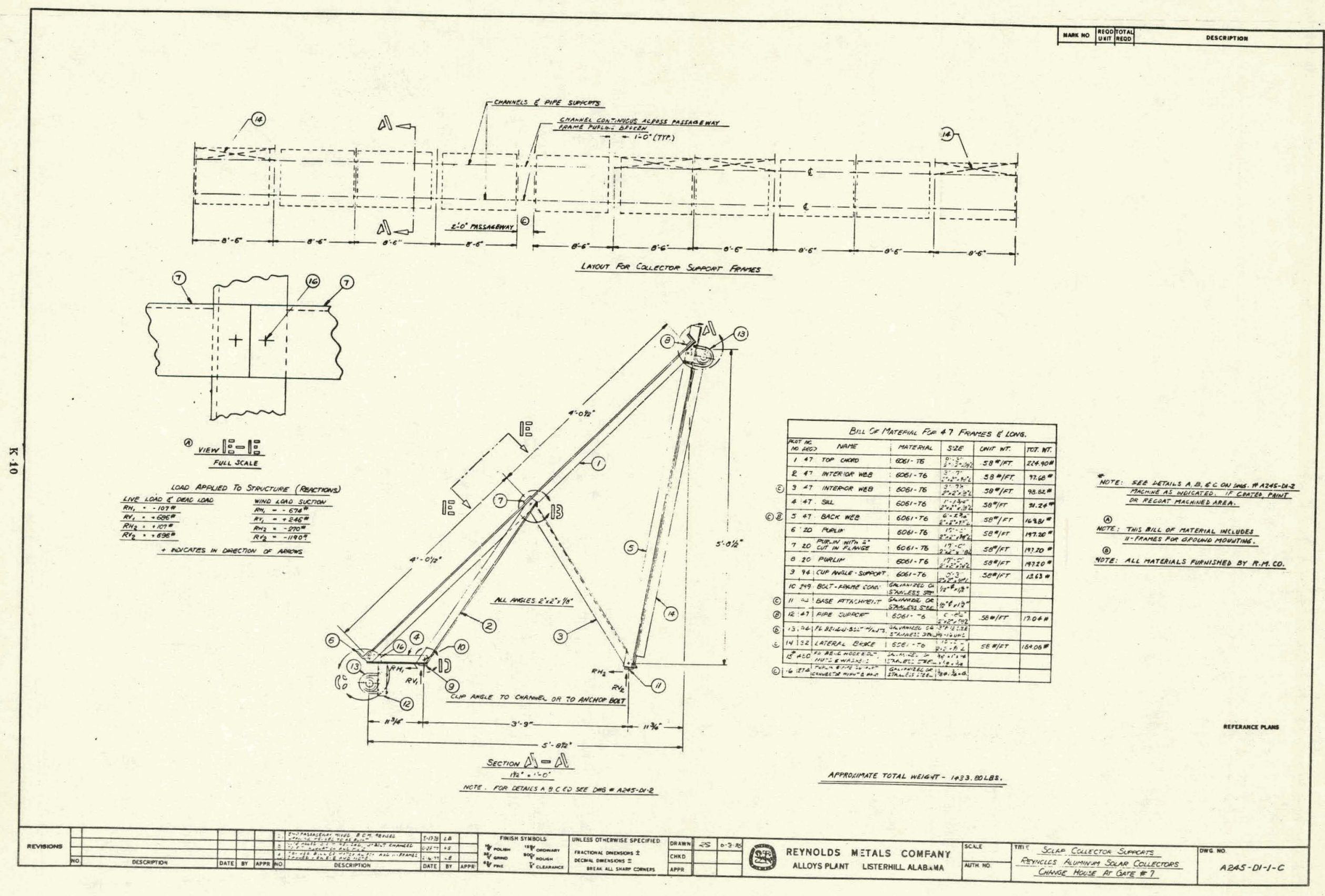




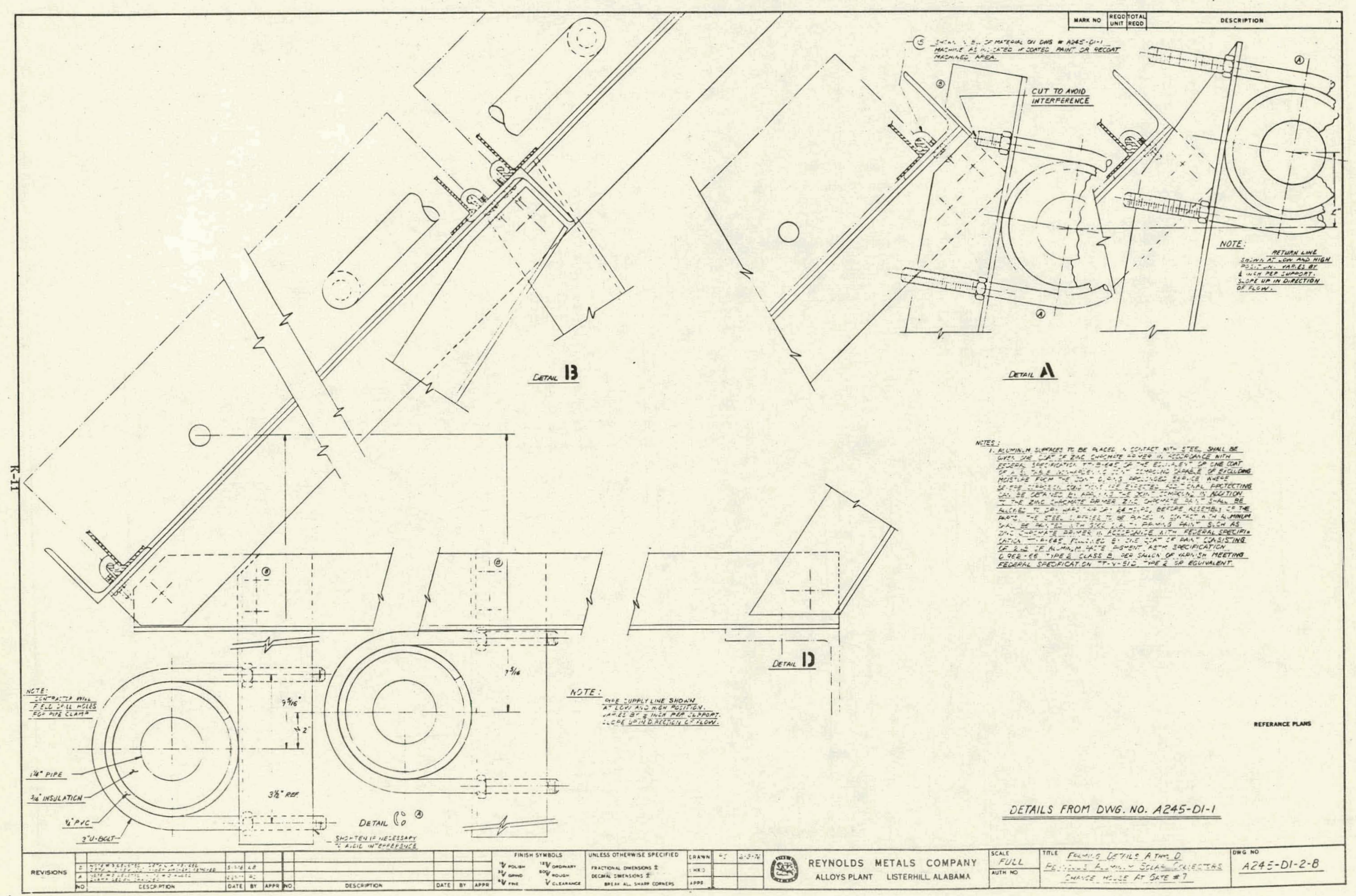




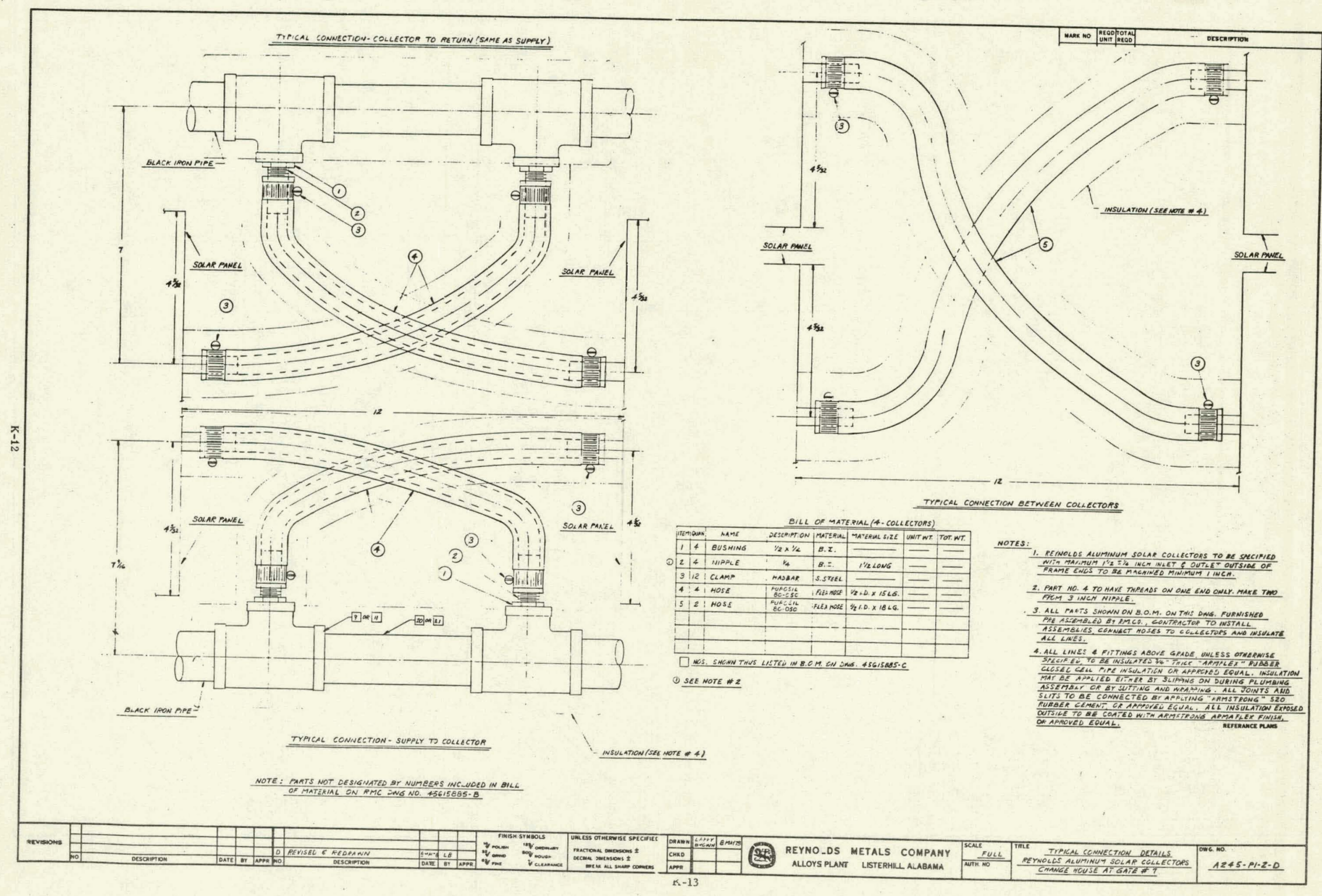

